

\section{DISCLAIMER}

This report was prepared as an account of work sponsored by an agency of the United States Government. Neither the United States Government nor any agency Thereof, nor any of their employees, makes any warranty, express or implied, or assumes any legal liability or responsibility for the accuracy, completeness, or usefulness of any information, apparatus, product, or process disclosed, or represents that its use would not infringe privately owned rights. Reference herein to any specific commercial product, process, or service by trade name, trademark, manufacturer, or otherwise does not necessarily constitute or imply its endorsement, recommendation, or favoring by the United States Government or any agency thereof. The views and opinions of authors expressed herein do not necessarily state or reflect those of the United States Government or any agency thereof. 


\section{DISCLAIMER}

Portions of this document may be illegible in electronic image products. Images are produced from the best available original document. 


\section{DISCLAIMER}

"This book was prepared as an account of work sponsored by an agency of the United States Government. Neither the United States Government ror any agency thereof, nor any of their employees, makes any warranty, express or implied, or assumes any legal liability or responsibility for the accuracy, completeness, or usefulness of any information, apparatus, product, or process disclosed, or represents that its use would not infringe privately owned rights. Reference herein to any specific commercial product, process, or service by trade name, trademark, manufacturer, or otherwise, does not necessarily constitute or imply its endorsement, recommendation, or favoring by the United States Government or any agency thereof. The views and opinions of authors expressed herein do not necessarily state or reflect those of the United States Government or any agency thereof."

This report has been reproduced directly from the best available copy.

Available from the National Technical Information Service, U.S. Department of Commerce, Springfield, Virginia 22161.

Price: Paper Copy $\$ 12.00$

Microfiche $\$ 3.50$ 
DOE/ID/12009-T1

GEOTHERMAL STUDIES

IN ARIZONA WITH

TWO AREA ASSESSMENTS

PROGRESS REPORT FOR THE PERIOD

JANUARY 16, 1979 - NOVEMBER 1, 1979

W. Richard Hahman, Sr.

BUREAU OF GEOLOGY AND MINERAL TECHNOLOGY

GEOLOGICAL SURVEY BRANCH

GEOTHERMAL GROUP

2045 N. Forbes Blvd.

Suite 106

Tucson, Arizona 85705

Date Published - November, 1979

PREPARED FOR THE

U.S. DEPARTMENT OF ENERGY

DIVISION OF GEOTHERMAL ENERGY AND THE

U.S. DEPARTMENT OF THE INTERIOR, BUREAU OF RECLAMATION UNDER

CONTRACT DE-FC07-79ID12009 


\section{TABLE OF CONTENTS}

Compliance with Contractual Requirements

Personnel of Program

Research Objectives

vi

Introduction and Review

ix

Preliminary Assessment of the Geothermal Potential of the Northern Hassayampa Plain, Maricopa County, Arizona

C. Stone

Geothermal Energy in Arizona

W. R. Hahman, Sr.

Preliminary Geothermal Assessment of the Willcox Basin

N. O. Jones

Preliminary Geothermal Assessment of the Hyder Area

N. O. Jones

A Geothermal Reconnaissance Study of the San Francisco River between Clifton, Arizona and Pleasanton, New Mexico

J. C. Witcher 
COMPLIANCE WITH CONTRACTUAL REQUIREMENTS

The principal investigator, W. Richard Hahman, Sr., in accordance with Article I and Article A-I of Appendix A of DOE Contract DE-FC07-79ID12009 has devoted his full time, from January 16, 1979, through July 15, 1979, to the contract work. This completes the first half contract work for DE-FC07-79ID12009. The principal investigator plans to devote his full time to the second half of this annual contract which continues to January 15, 1980. The principal investigator and the program are in compliance with the requirements of the contract.

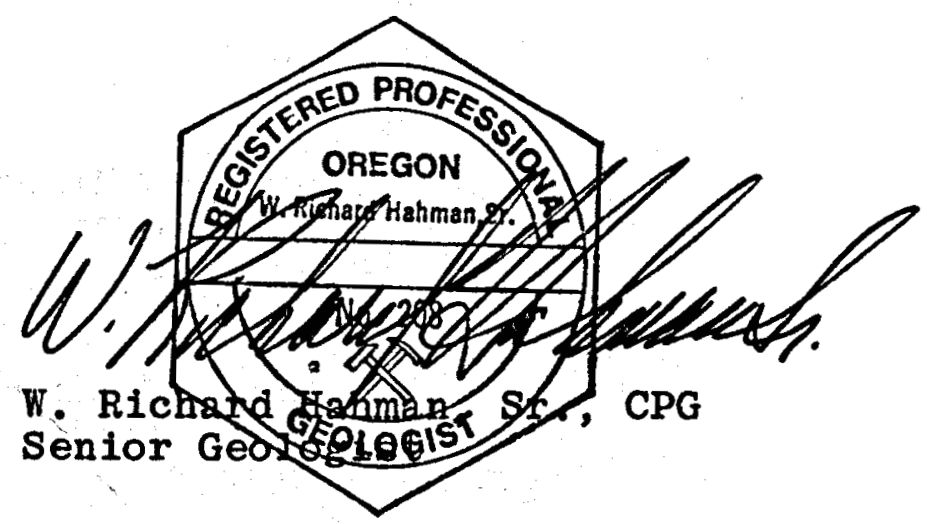


Principal Investigator

W. Richard Hahman, Sr., Senior Geologist Bureau of Geology and Mineral Technology Geological Survey Branch

University of Arizona

Staff Geologists

Nile 0. Jones, Senior Geologist

Bureau of Geology and Mineral Technology Geological Survey Branch

University of Arizona

Claudia Stone, Geologist

Bureau of Geology and Mineral Technology Geological Survey Branch

University of Arizona

James C. Witcher, Geologist

Bureau of Geology and Mineral Technology Geological Survey Branch

University of Arizona

Associate

Alice Campbell

Geohydrologist/Engineering Geologist

Tucson, Arizona

Geologic Technicians

Michael M. Ciarochi

Bureau of Geology and Mineral Technology Geological Survey Branch

University of Arizona

Daniel B. Dwyer

Bureau of Geology and Mineral Technology Geological Survey Branch

University of Arizona

Drafter (Part-time)

Bette Holt

Bureau of Geology and Mineral Technology Geological Survey Branch

University of Arizona 
Accountant (Part-time)

Gus Mortenson

Bureau of Geology and Mineral Technology Geological Survey Branch

University of Arizona

Secretaries

Mrs. Linda Stawiski

Bureau of Geology and Mineral Technology Geological Survey Branch

University of Arizona

Mrs. Mildred Underwood

Bureau of Geology and Mineral Technology Geological Survey Branch

University of Arizona

Mrs. Dorothy Lewis

Bureau of Geology and Mineral Technology Geological Survey Branch

University of Arizona

Outside Advisors

A. W. Laughlin, Geologist/Geochemist

Los Alamos Scientific Laboratory

University of California

Los Alamos, New Mexico

Francis G. West, Geologist/Hydrologist

Los Alamos Scientific Laboratory

University of California

Los Alamos, New Mexico 
RESEARCH OBJECTIVES

The ongoing Geothermal Project for Arizona has several short- and long-term objectives. One facet of the program is to develop successful exploration techniques designed to aid the serious parties in the location and evaluation of low- to moderate-temperature geothermal resources. Efficient and cost-effective exploration requires the close coordination of geology, geochemistry and geophysics. The worth of such a program can be shown only through successful case studies. Another major objective of the program is to demonstrate the utility and cost-effectiveness of low- to moderatetemperature resource development within Arizona. Current plans call for at least three demonstration projects in separate areas within the state. The first projects will provide for resource testing and training. They will also help to point out the diversity of applications associated with this alternative energy resource. Successful completion of this phase of the program will result in positive cash flow enterprises that do not totally rely on conventional energy sources.

The "Exploration and Evaluation" section of this proposal sets forth some site-specific programs designed for specific potential users. Several of these users have requested from the Geothermal Project technical assistance in the location and development of usable geothermal resources. Such requests 
are often accompanied by stated or implied temperature, water volume, or physiographic requirements that can be met only by a thorough understanding of the resource base.

While the detailed site-specific exploration, evaluation and development programs are in progress, the reconnaissance exploration and data gathering process will continue to locate new areas of interest. The reconnaissance program covers all of Arizona; however, most of the current data are from the Basin and Range Province. Much of this is due to the distribution of the population, agricultural ventures, industry and mining. The reconnaissance program will attempt to extend the resource base northward into the Transition Zone and the Colorado Plateau.

The cooperative arrangement between the Geothermal Project and Dr. Ed Wolfe, U.S.G.S., Flagstaff, will be continued. The Geothermal Project will provide financial support for two doctoral candidates during the school year, while the U.S.G.S. provides support for summer field mapping in the Springerville volcanic field. A detailed explanation of this program is included later in the proposal.

Another objective of the 1980 program is to continue building a special library for public use on geothermal energy and related subjects. This comprehensive library is located at the Bureau of Geology and Mineral Technology, Geological Survey Branch, Tucson, Arizona.

The current program also provides information and data to the U. S. Geological Survey GEOTHERM program. The Geothermal 
Project currently has over 26,000 well locations, temperatures and water analyses. Significant data additions are expected this year. The file has had to be computerlzed because of the size of the data base.

Computer data w1ll ald in the publication of Arizona's Geothermal Map 2. Plans are for 1t to show all known wells and springs with temperatures in excess of $30^{\circ} \mathrm{C}$, contours of corrected silica geothermometers, and earthquake epicenters with their magnitude or intensity, and additional data is contemplated. It is expected that this map will be printed at a scale of $1: 1,000,000$ or $1: 500,000$ by the National Oceanic and Atmospheric Administration. This map should be available in 1980. Other maps to be published by the Bureau of Geology and Mineral Technology, Geothermal profect during 1979-1980 will be a 1:500,000 scale gravity map of Arizona, contoured at 5 milligals, and 23 gravity maps at 1:250,000 scale (AMS series). These more detailed maps will contain the most current gravity data and will be contoured at 2 milligal intervals. The 23 maps will be made available as open file as soon as they are completed and will be published as a set at the earliest possible moment. 


\section{INTRODUCTION AND REVIEW}

The present Arizona geothermal program was initiated in May, 1977 in response to prior geothermal research and reconnaissance work in the state. Much of this preliminary work was funded by the federal government. Prior to May, 1977 there was no cohesive program in Arizona:

The initial program with the Arizona Bureau of Geology and Mineral Technology, Geological Survey Branch was limited in scope and direction. Once initiated, however, the program rapidly expanded to include all portions of the state. In the past 28 months the project staff was increased from one fulltime geologist and a half-time research assistant to four fulltime geologists and support staff.

Much of the work conducted by the Geothermal Project staff is of an ongoing nature. The data base of water well and spring temperatures and water chemistry has grown to the point where computer assistance is required, Nearly 30,000 water records are currently on file. Close to 2,000 recorded temperatures exceed $30^{\circ} \mathrm{C}$, and over 100 of them exceed $60^{\circ} \mathrm{C}$. The resource base has grown from several tens of anomalous temperature values to 37 well defined resource areas. Additional data gathering will no doubt increase this number.

The contents of this semi-annual report reflects the coalescence of ldeas, goals and data. Three of the papers are of a site-speciflc nature. The fourth paper, written by $w$. Richard Hahman, Sr., was submitted to Geothermal Energy magazine for publication in their October, 1979 issue and is publishea here with permission from Geothermal World Corporation. 


\section{PRELIMINARY ASSESSMENT OF THE \\ GEOTHERMAL POTENTIAL OF THE NORTHERN KASSAYAMPA PLAIN, MARICOPA COUNTY, ARIZONA}

By

Claudia Stone 


\section{INTRODUCTION}

A preliminary assessment of the geothermal potential of the western half of the northern Hassayampa Plain has been made. A single shallow well with a measured temperature of $51^{\circ} \mathrm{C}$ initially called attention to the area.

Field investigations were carried out between January and July, 1979. The field program consisted of (1) temperature logging of available water wells and mineral test holes, (2) collecting soil samples for mercury analysis, (3) taking water samples for major cation and anion analyses, and (4) conducting reconnaissance geologic mapping along the northeast side of the Belmont Mountains. Parts of this report are taken from published maps and reports and from unpublished field investigations conducted in $1972-73$ by Fugro, Inc., Long Beach, California, and used here with their permission.

\section{GENERAL SETTING}

The northern Hassayampa Plain is bounded by the Hieroglyphic Mountains on the northeast, the Vulture Mountains on the north, and the Belmont and White Tank Mountains on the southwest and southeast sides (Fig. 1). The Hassayampa River, an intermittent stream, flows south through the center of the region and defines the approximate eastern boundary of the present area of investigation. Other boundaries of the study area are the Belmont and Vulture Mountains. 


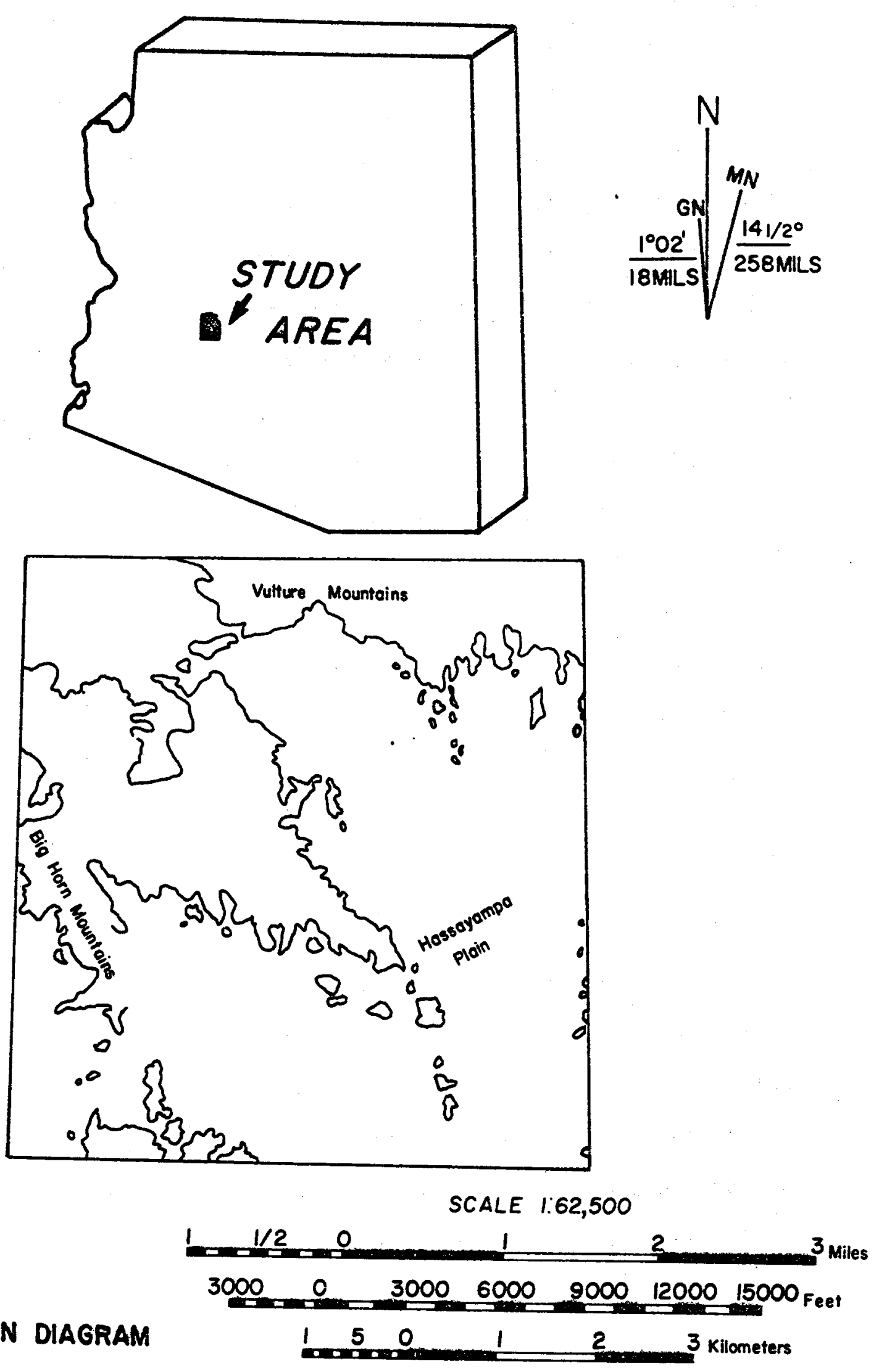


Daily average temperatures at Wickenburg, slightly northeast of the Vulture Mountains, vary between $8.2^{\circ} \mathrm{C}$ $\left(46.7^{\circ} \mathrm{F}\right)$ and $30.4^{\circ} \mathrm{C}\left(86.7^{\circ} \mathrm{F}\right)$ with a mean annual temperature of about $18.4^{\circ} \mathrm{C}\left(65.1^{\circ} \mathrm{F}\right)$. Precipitation ranges from 0.15 to 2.24 inches per month; the annual normal precipitation at Wickenburg is 10.76 inches (NOAA, 1973).

\section{HYDROLOGIC SETTING}

\section{Surface Water}

Throughout the entire Hassayampa drainage area (1074 $\mathrm{km}^{2}$ ) the average annual runoff is less than 0.1 inch. Surface runoff in the study area is channelled into two major intermittent streams, Star Wash and Jackrabbit Wash, which trend south and southeastward, respectively. Star Wash enters Jackrabbit Wash east of the Belmont Mountains. Several miles further south Jackrabbit Wash enters the Hassayampa River.

Ground Water

Contours of water-level altitudes above mean sea level (Fig. 2) were drawn on the basis of available water well data, bedrock outcrops, and an unpublished gravity survey of 1 imited extent $\left(107 \mathrm{~km}^{2}\right)$ in the Indian Buttes area (Fugro, 1979). The paucity of data renders any interpretation conjectural and subject to revision as additional data are acquired. With this understanding, an attempt is made to explain the hydrologic setting of the region. 
The altitude of ground water above mean sea level decreases to the southeast, reaches a low northeast of the Belmont Mountains (Fig. 2) and then gently rises again, creating a saddle-like configuration. This undulation is likely caused by either shallowing of bedrock between the Belmont Mountains to the west and the White Tank Mountains to the east, or mounding of ground water between the two ranges. In either case, it appears that the constriction between the Belmont and White Tank Mountains creates a natural ground-water divide between the northern and southern Hassayampa areas. The shallow water-level gradients in the center of the study area, opposed to steeper gradients closer to the range fronts, indicate a highly permeable aquifer beneath the central portion of the northern Hassayampa Plain.

Depth to water below the land surface ranges from about $13 \mathrm{~m}$ in the Belmont Mountains to a reported depth of greater than $200 \mathrm{~m}$ south of the Vulture Mountains. Shallow water levels along the northeast side of the Belmont Mountains indicate that the water there is being held up by a pediment. Near the center of the plain, depth to water is about $145 \mathrm{~m}$ and it decreases to the southeast.

Recharge to the aquifer is from the contiguous mountain ranges, with the rate of recharge being. small owing to low precipitation. The intermittent nature of the Hassayampa River makes it unlikely that much recharge to the ground 
Figure 2. PROPOSED BEDROCK AND HYDROLOGIC CONDITIONS

\section{EXPLANATION}

- $\frac{435}{1645}$

$---1300---$

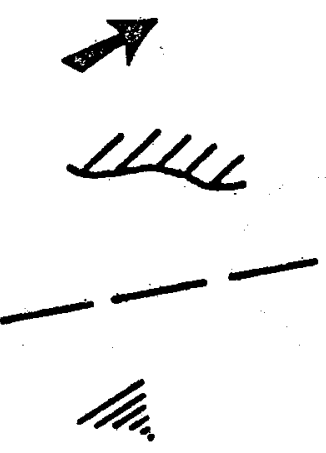

Upper number is depth to water below land surface (feet); lower number is approximate altitude of water level above mean sea level (feet).

Contour of approximate water level above mean sea level (feet). Dotted where data are insufficient. Contour interval is 100 feet.

General direction of ground water flow.

Bedrock outcrop.

Inferred faults.

Area of shallow bedrock. 


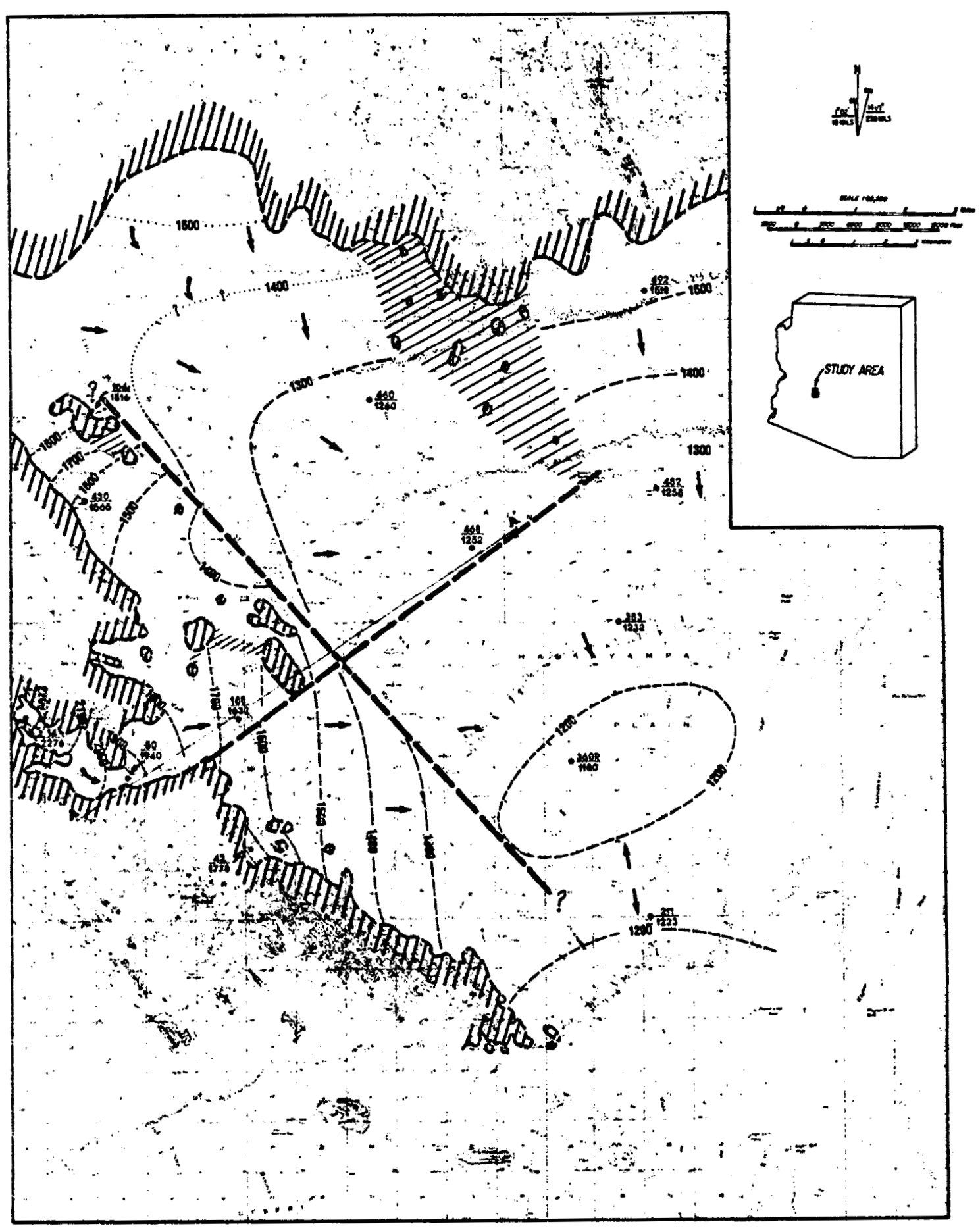

Figure 2. Proposed Bedrock and Hydrologic conditions, Northern Hassayampa Plain, Arizona. 
water system is derived from this source. Published ground water data from the study area are presently inadequate to quantitatively evaluate water balance elements such as recharge and withdrawal rates and recent water level changes. 
The Hassayampa Plain lies within the Basin and Range physiographic province of west-central Arizona. The northern Hassayampa Plain is separated from the southern plain by an eight-mile wide constriction caused by the proximity of the Belmont to the White Tank Mountains.

Vulture Mountains. Published reports on the Vulture Mountains are generally limited to early accounts of mining activity at the Vulture gold mine on the south side of the mountain. On the Geologic Map of Arizona, Wilson, Moore and Cooper (1969) show the Vulture Mountains as being composed of Precambrian granite, gneiss, and schist, and Cretaceous andesitic and rhyolitic rocks. These rocks are intruded by sills, plugs, and north-trending dikes of lateCretaceous to Tertiary age. Tertiary-Quaternary basalt flows cap much of the west end of the complex. Rehrig and Heidrick (1976) identified distinctive tectonically-oriented structures in the Vulture Mountains which they identified as Laramide and late-Tertiary in age. A comprehensive report by Rehrig, Shafiqullah, and Damon on the geochronology and geology of the Vulture Mountains is in press.

Belmont Mountains. Published references to the Belmont Mountains and the northern Hassayampa Plain are not found in the literature. Results of unpublished reconnaissance geologic mapping along the south side of the Belmont Mountains and within the northern Hassayampa Plain were made available 
for this study by Fugro, Inc., Long Beach, Californta. Additional geologic information is based on field investigations and air photo interpretation.

The Belmont Mountains is a small northwest-trending range that separates the northern Hassayampa Plain from the southern plain. The southeast end of the range terminates with a pile of Cretaceous (?) andesite with maximum elevation of $675.3 \mathrm{~m}$. The main section of the range comprises a barren granite ridge about $7.2 \mathrm{~km}$ long, with a maximum elevation of $956.4 \mathrm{~m}$. The age of this granite is shown as precambrian on. the state geologic map (Wilson and others, 1969). To the northwiest of the granite ridge are low hills of Precambrian schist and remnants of Cretaceous andesite (Wilson and others, 1969). In the study area there are no granitic outcrops northeast of the granite ridge. However, northeast of the schist and andesite hllis, numerous granitic hills protrude through the detrital sediment as far north as Jackrabbit Wash, confirming the existence of a pediment there. A geologie cross section (Fig. 3) shows details across the area. Of the isolated outcrops examined, one hill is conposed of granite intruded into schist. This granite is quite distinct from other granitic rocks examined. Specifically, the schist-intruding granite is lacking biottte which the other granites contain. Uehedral magnetite in this rock is ubiquitous. Phenocrysts of subhedral to euhedral quartz, alkali feldspar, and plagioclase are abundant. The 


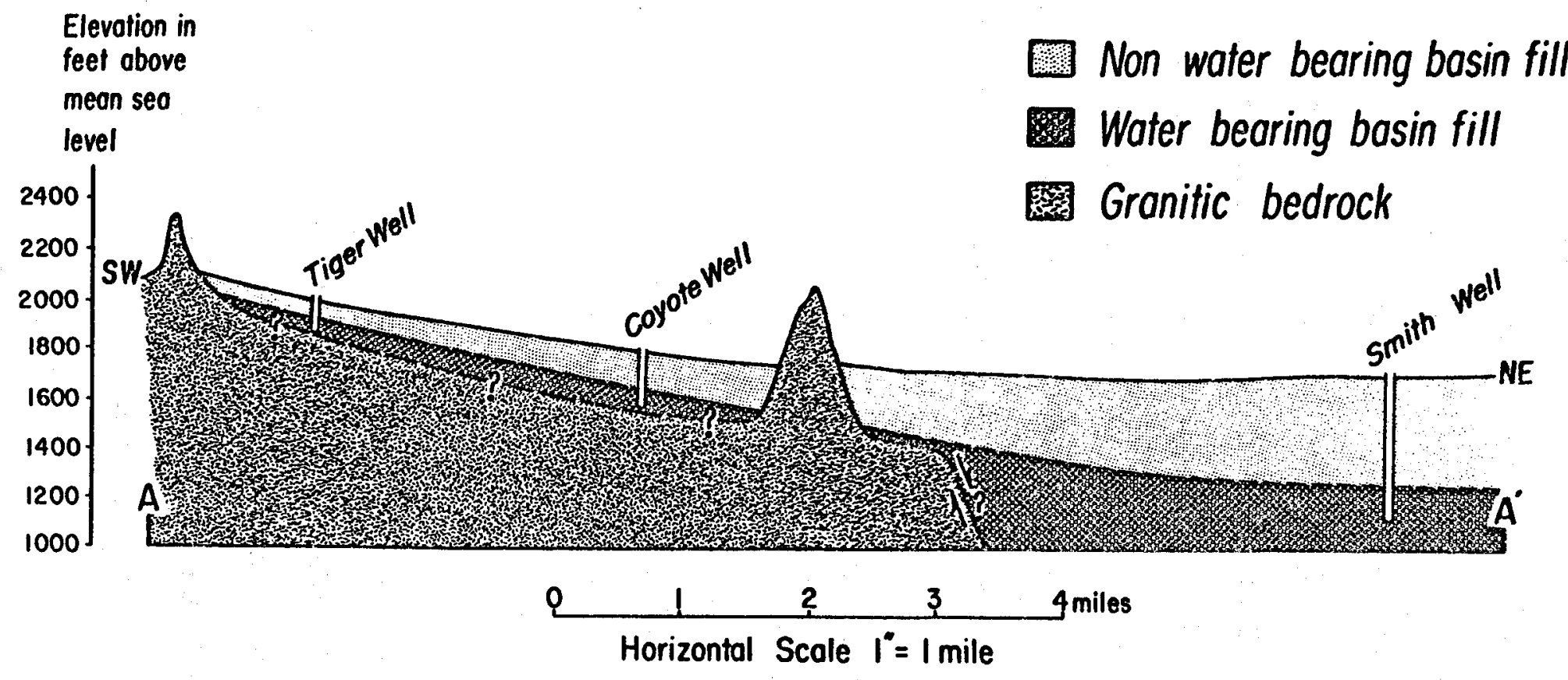

Figure 3. SW-NE cross section ( $\left.A-A^{\prime}\right)$ showing water-bearing and non-water bearing basin fill and inferred Jackrabbit Wash fault. 
groundmass has been destroyed by potassic'alteration, and late-stage propylitic alteration is indicated by small to large clots of chlorite/epidote. Quartz phenocrysts comprise about 17 modal percent of the schist-intruding granite. In contrast, the other granite samples are allotriomorphic granular. Biotite comprises about 2.8 per cent and quartz, 25 to 35 percent of the rock. Epidote is present in trace amounts only. Feldspar is being altered to sericite.

Two inferences can be made from these observations. 1) The granitic rocks represent at least two separate episodes of intrusion and (2) each had a distinct thermal history. With respect to the episodes of intrusion, it is likely that there were more than two events. Zones of highly fractured rock probably surround these plutons and could provide open fracture networks for the storage or circulation of hydrothermal fluids at depth. The distinctive thermal histories suggest that at least some of the fracture channels are sealed by secondary mineralization due to hydrothermal alteration. However, the same hydrothermal alteration could equally well have created an impermeable, shallow cap rock, sealing off a geothermal reservoir at depth.

Northwest of the Belmont Mountains, the rocks are identified as Cretaceous andesite by Wilson and others (1969), but the rock-type identification is at least 
partly in error. Field investigations reveal the occurrence of extensive, northwest-trending ridges of black and gray obsidian and banded rhyolite flows, some of which exceed $75 \mathrm{~m}$ in height. The obsidian frequently exceeds $15 \mathrm{~m}$ in thickness, is phenocryst free, and is very dense and coherent. In places it rests atop the rhyolite flows and forms the ridge top. In other areas the obsidian is interbedaed beneath rhyolite flows. The entire sequence dips moderately to the southwest. Additional field work is necessary in this area to determine (1) the source area of the rhyolitic rocks, (2) structural relationships, and (3) whether the sequence represents a series of rhyolitic lava flows, the more likely explanation, or a composite ash flow event in which the obsidian layers represent the densely-welded interiors of individual ash flow cooling units. (A sample of the obsidian is presently being age dated, as a young age, less than about one m.y., would provide a significant heat source for a geothermal resource.)

Structure. Two discrete tectonic orientations are identified in the Vulture Mountains by Rehrig and Heidrick (1976). An older set of strike maxima, measured along an elongate Laramide pluton and associated dikes in the Vulture Mountains, is oriented northeast to east and corresponds with strike maxima, also of Laramide age, determined by the authors for eight-out-of-nine other regions in the Arizona Basin and Range province. A younger set of strike 
maxima are oriented north-northwest, perpendicular to the earlier trend, and are late Tertiary in age. The authors interpret the two tectonic orientations as evidence of former stress fields signifying the following:

"...the Laramide extensional pattern developed under weak, lateral ENE-directed compression combined with differential uplift along multiple NNW to NW-elongate arches, while late Tertiary Basin and Range structures formed under the influence of a non-compressive or tensional stress field which resulted in regional WSW-ENE distension. Preexistent basement anisotrophy is considered a possible influence on both Laramide and late Tertiary structure.

"The opposing regional stress patterns for the two time periods are interpreted as the large-scale effects of plate tectonics. Weak, east-northeastdirected compression was produced by subduction along the Farallon-American plate boundary during the Laramide orogeny (50-75 m.y.B.P.).

"The subsequent release of this lateral compression and attendant inception of Basin and Range tensional stresses occurred upon destruction of the subduction zone about $30 \mathrm{~m} . \mathrm{y} . \mathrm{B} . \mathrm{P}_{\text {., }}$, and motion spread northwestward as transform faulting occurred along the west edge of the American plate...."

Three distinct structural trends have been identified in the study area. These trends can be seen on the isothermal maps (Figs, 4 and 5), on the Fluoride (Fig, 6) and Mercury (Fig. 7) maps, and on the Aeromagnetic map (Fig. 8). Two of the trends (NNW and NE) correspond to the Laramide and late-Tertiary Vulture Mountain stress fields of Rehrig and Heidrick (1976). The third structural trend (NW), of unknown age, is also evident from the Landsat lineament map (Lepley, 1978) (Fig. 9) and from air photo interpretatior. This northwest trend is especially apparent north of the 


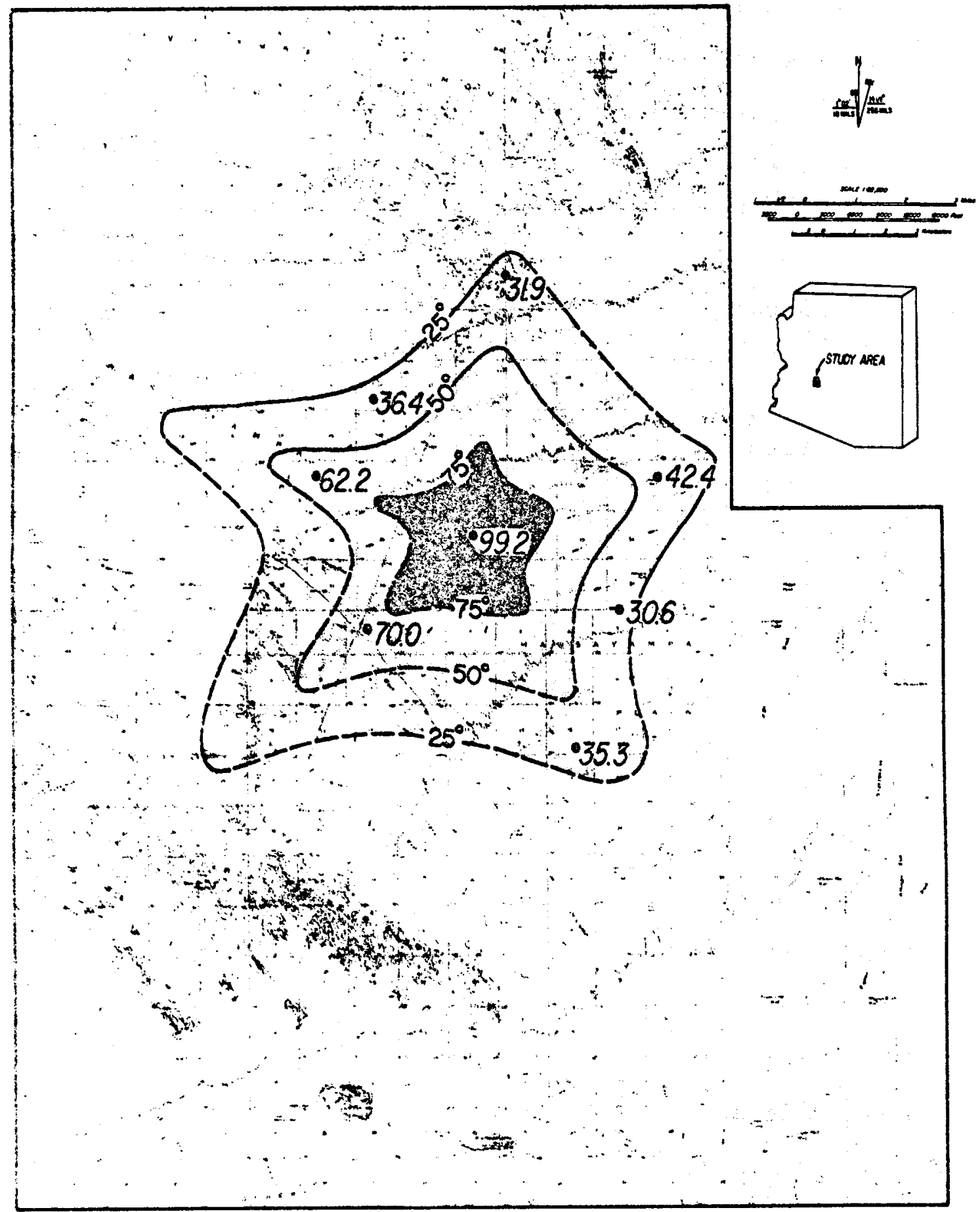

Figure 4. Projected Temperatures $\left({ }^{\circ} \mathrm{C}\right)$ at $500 \mathrm{~m}$ Depth. 


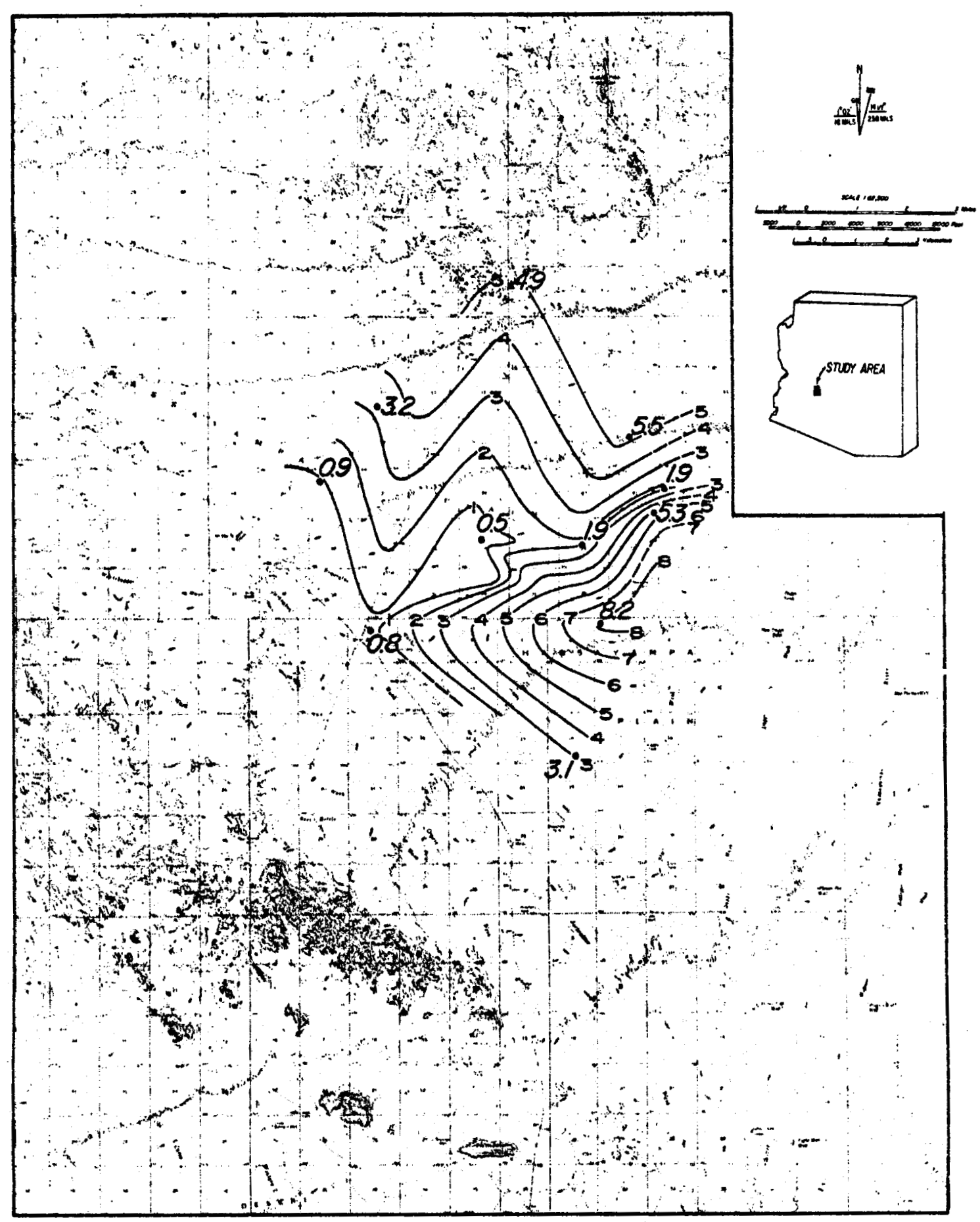

Figure 5. Projected depths in $\mathrm{km}$ to $100^{\circ} \mathrm{C}$ 1sotherm. 


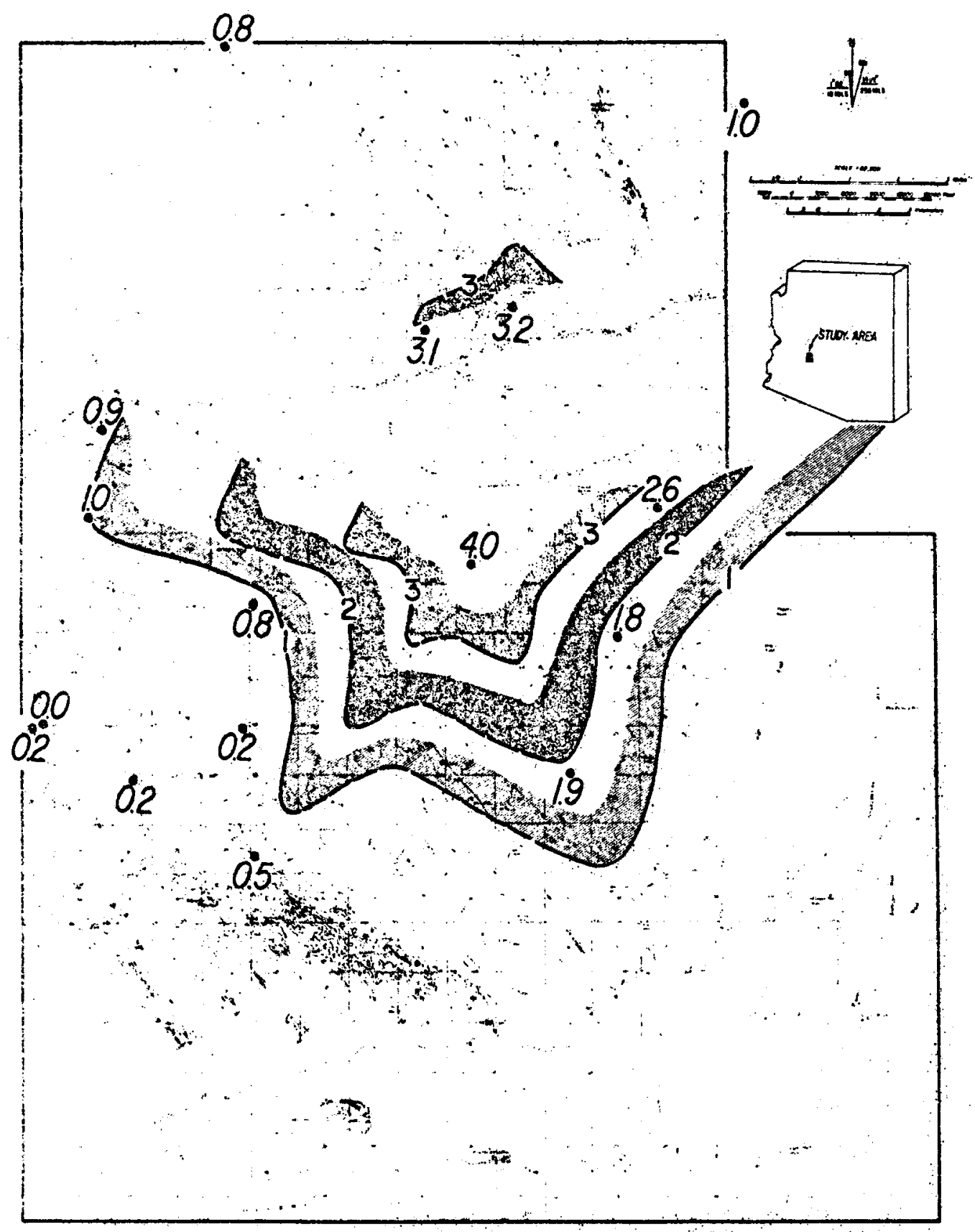

Figure 6. Fluoride Concentrations (Milligrams Per Itter). Contour interval is one $\mathrm{mg} / \mathrm{l}$. 


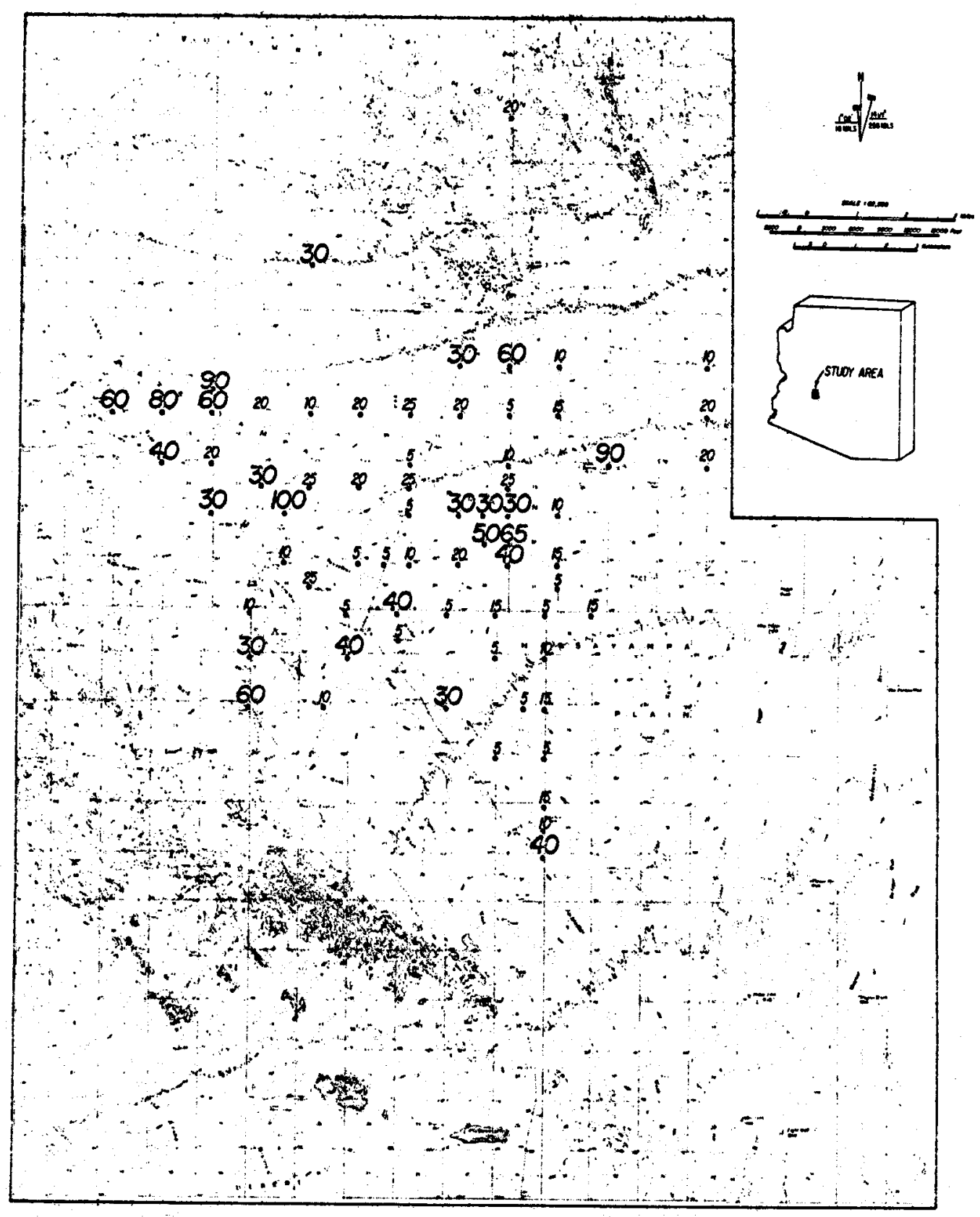

Figure 7. Mercury Concentrations (Parts Per Billion). 


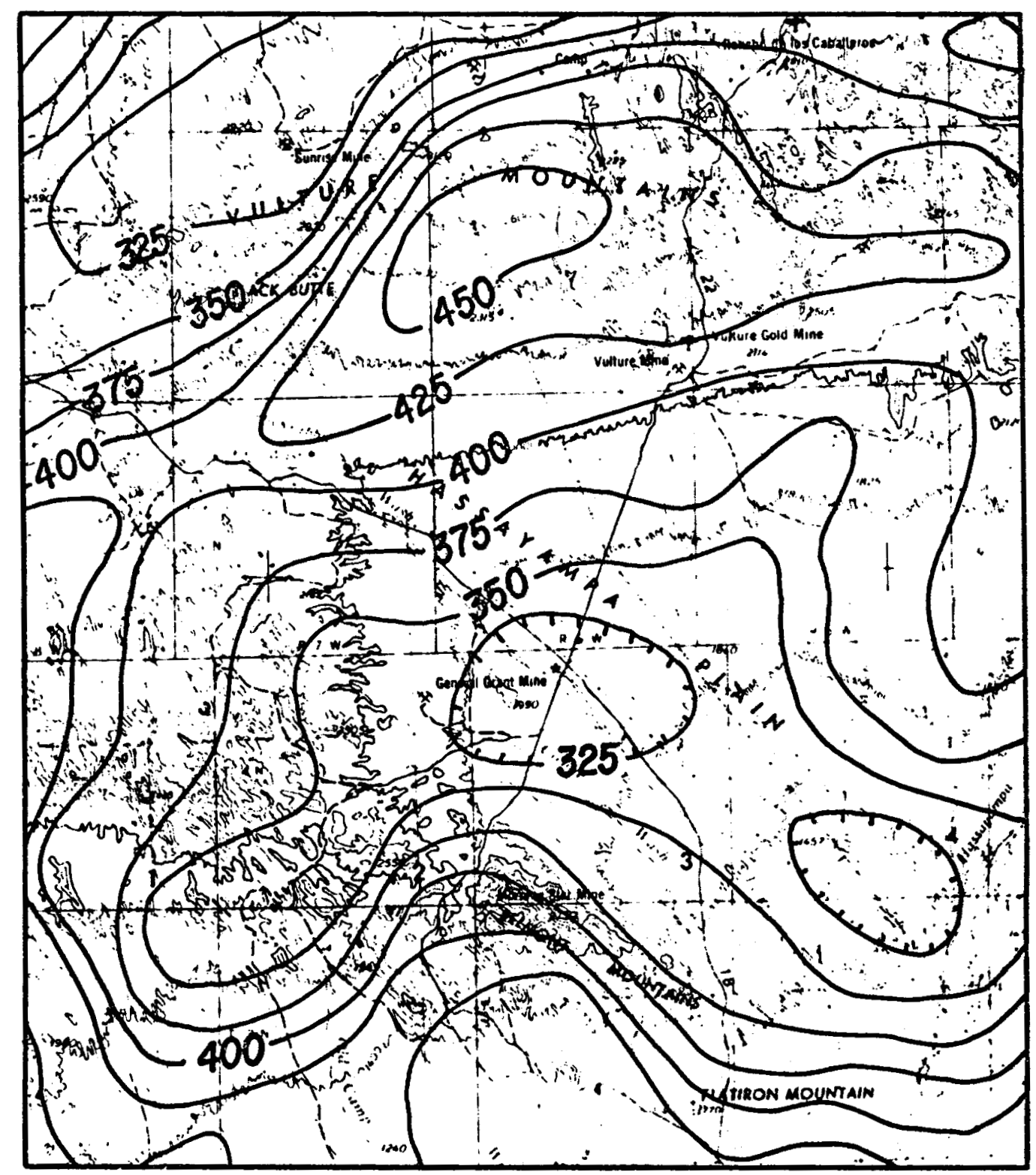

Figure 8. Residual Aeromagnetic Map (From Sauck and Sumner, 1970). Contour interval is 25 Gammas. 


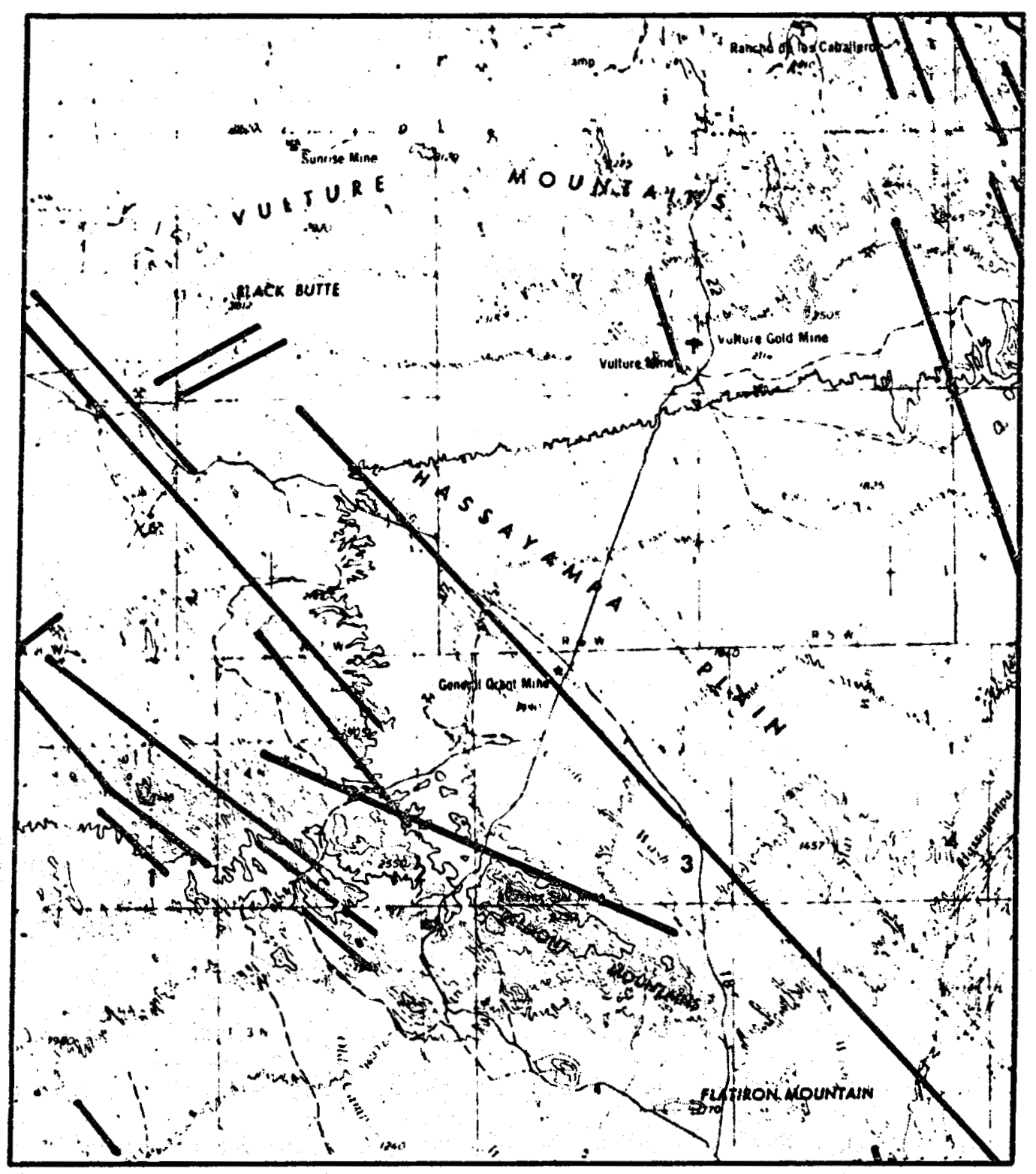

Figure 9. Landsat Lineaments (From Lepley, 1978). 
Belmont Mountains where Jackrabbit Wash trends southeastward along the trace of a prominent northwest-directed Landsat lineament. In addition numerous northwest-trending lineaments occur in the eastern Vulture Mountains. A single, shorter Iineament strikes northwest through the Vulture Mine area and probably is the trace of the Talmage Fault (Hutchinson, 1921). The correlation of present-day structural trends with Laramide and late-Tertiary trends indicates that these features have been extant for many millions of years; that the channelways still may be open and may provide conduits for fluids moving through or up from the deep subsurface. The intersection of these tectonic features may be the source of local upwellings of warm water.

\section{GEOPHYSICS:}

Aeromagnetics. The Residual Aeromagnetic Map of Arizona (Sauck and Sumner, 1970) (Fig. 8) shows two closed magnetic lows in the northern Hassayampa Plain, one centered on Jackrabbit Wash, the other several miles to the southeast. A second, less prominent feature is a northeast-trending trough of low magnetism, only slightly higher than the two ciosed magnetic lows, which crosses north of the Belmont liountains, crosses the more northerly magnetic low and the Hassayampa Plain, and dies out west of the Hassayampa River. The magnetic trough nearly coincides with the proposed northeast-trending fault ( $F i g .2$ ), and one closed magnetic low occurs at the intersection of this fault and the 
nor thwest-trending Jackrabbit Wash fault. The amplitude of the magnetic features is low and their significance is uncertain. One explanation for the observed features is the upwelling of hot water along the fault or at the fault intersection, with attendant hydrothermal alteration of magnetite to pyrite which would create a magnetic low.

Gravity. Gravity data in the northern Hassayampa plain are scarce so that any attempt at interpretation is difficult. From the data available, little in the way of structural features is apparent (Fig. 10). Most likely the liassayampa plain comprises a relatively thin cover of mountain-derived sediments overlying a bedrock basement the depth to which varies locally. A bedrock high, evident from isolated schist outcrops, extends south from the Vulture Mountains nearly to Indian Buttes (Fig. 2), but it is not known whether this feature is due to local basement relief or to faulting.

Thermal Gradients: Thermal gradients were measured in eight wells, and Birdwell temperature logs were provided by Fugro, Inc. for three additional test holes in the study area (Fig. 11). The data are listed in Table 1. Most of the temperature gradients are normal for the Basin and Range province, indicative of recharge to the regional aquifer. The three highest gradients, wells A, B, and C (Fig. 11), which are exceptions, are spacially closest to the fault intersection. Possible explanations for the high gradients 


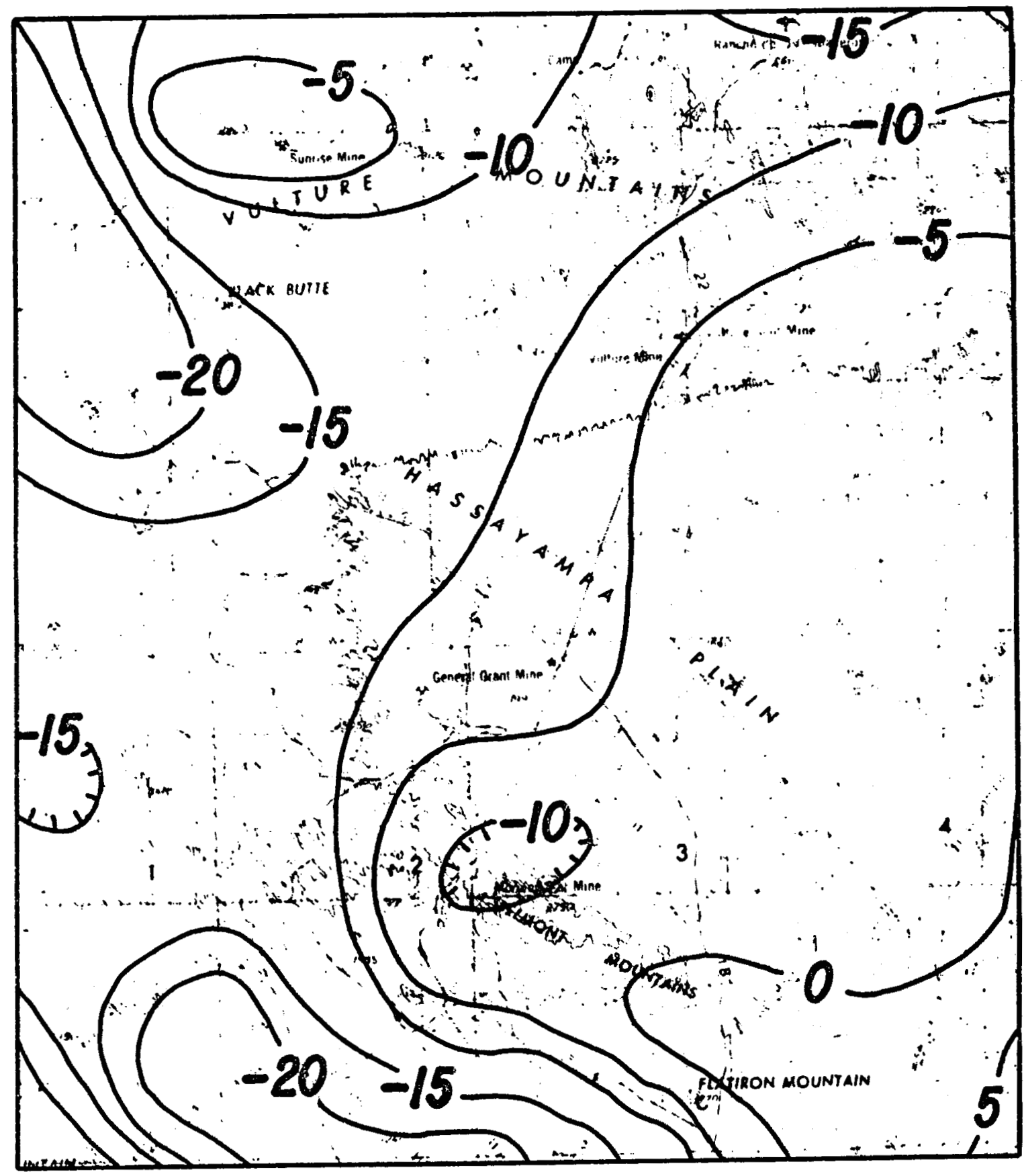

Figure 10. Terrain Corrected Residual Bouguer Gravity Map (From Lysonski and Sumner, 1979, Unpublished Data). Contour interval is 5 Milligals. 


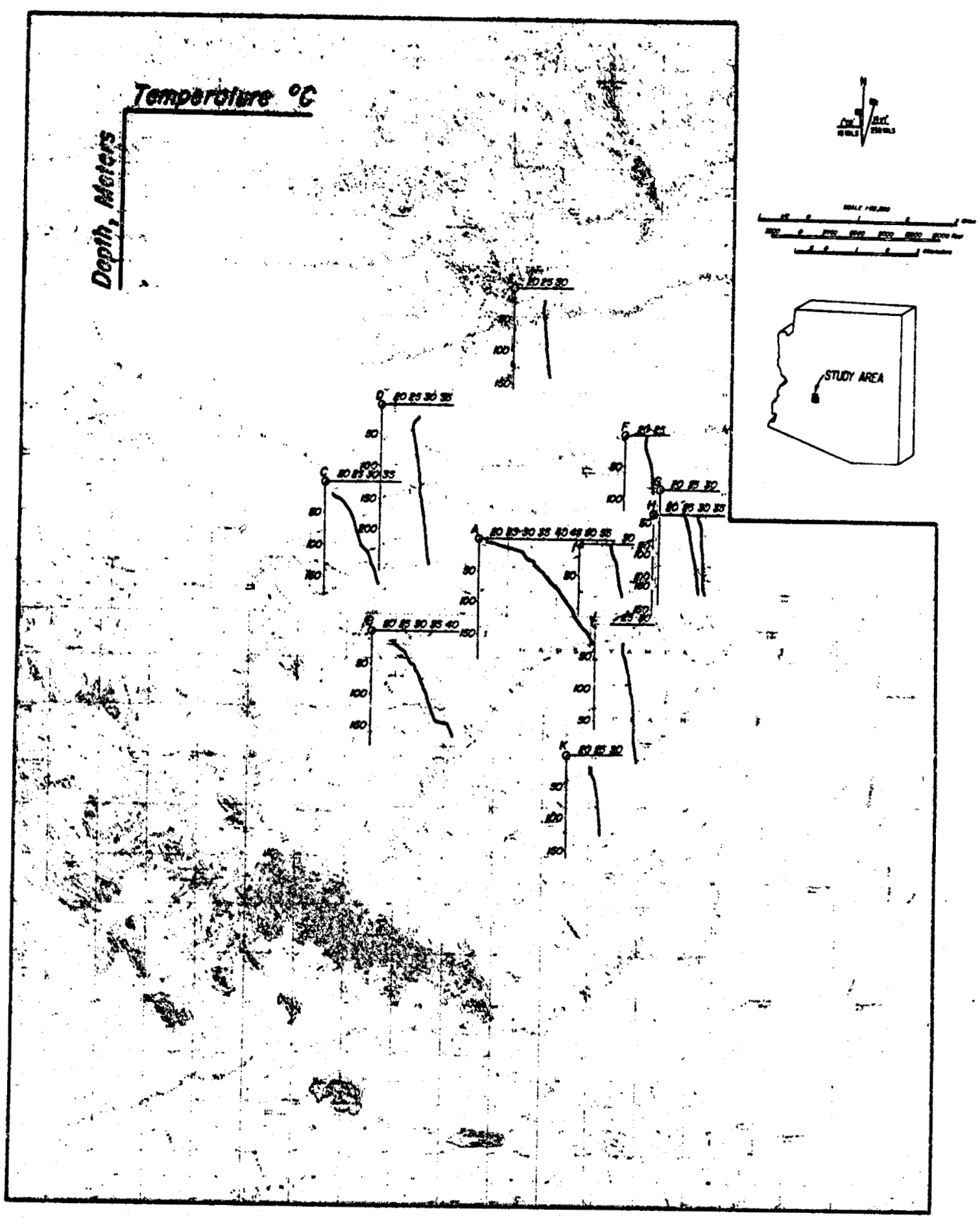

Figure 11. Measured Geothermal Gradients $\left({ }^{\circ} \mathrm{C} / \mathrm{km}\right)$. Circles indicate well locations. 
Table 1. Measured Geothermal Gradients, Northern Hassayamaa plain, Arizona

We11

No.

A

B

C

D

E

F

G

HI

I

$J$

$\mathrm{K}$
Township and Range

Location

(Gila-Salt Meridian)

$5 N-6 W-25$ SE NW

$4 \mathrm{~N}-6 \mathrm{~W}-4$ NE NE

$5 N-6 W-21 N W$

$5 N-6 W-10$ SE SW

$6 \mathrm{~N}-5 \mathrm{~W}-31 \mathrm{SW} N \mathrm{NW}$

$5 N-5 W-16$ SE NW

$5 N-5 W-22$ SW NE

$5 N-5 W-21$ SE SE

$5 N-5 W-29$ SE NW

$4 N-5 W-5 N W \quad N E$

$4 N-5 W-18$ SW SE
Geothermal

Gradient

$\mathrm{C} / \mathrm{km}$

140.1

94.8

87.5

23.2

15.6

18.3

41.4

19.0

51.8

9.0

24.8 
include: (1) shallow convective circulation of warm water, (2) refraction of heat across a range-bounding fault, and (3) rise of warm water along a range-bounding fault.

(1) High thermal gradients measured at relatively shallow depths may result from shallow convective circulation of warm water (Batzle and Simmons, 1977). However, shallow convective circulation seems an unlikely explanation in the study area because of the widespread occurrence of normal gradients. Additional zones of warm-water discharge should be randomly located throughout the area, and these are not observed. In addition the ground-water gradient points to the steady flow of ground water to the southeast, rather than to convective circulation.

(2) In a non-geothermal area, upwarping of isotherms and a small heat flow anomaly may result from refraction of heat, caused by the thermal conductivity contrast across a range-bounding fault (Blackwell and Chapman, 1977). This is a more plausible explanation of the observed gradients, but still is not entirely satisfactory. Gradients B and C (Fig. 11) are located along the range-bounding fault, but so is gradient $\mathrm{K}$ which, according to this explanation, might reasonably be expected to be much higher.

(3) The most plausible explanation for the observed gradients seems to be the rise of hot water along the rangebounding fault (Blackwell and Chapman, 1977; Chapman and other, 1978; Hahman, in press) and at the fault intersection. 
Surface water percolates down through faults, fractures, and permeable beds where it is heated by temperatures that normally increase with depth. The water may or may not be stored in a reservoir for some period of time. Difference in piezometric head between recharge and discharge zones, and the reduced density of warm water eventually force the thermal waters toward the surface through a fault zone. Hot springs may or may not occur along the range front to signal this phenomenon. Where hot springs are absent, leakage of thermal waters into the alluvium can be significant. Fault intersections, leaking greater volumes of hydrothermal water into the surrounding rock and alluvium, could be expected to cause extensive hydrothermal alteration. As stated above, such alternation of magnetite to pyrite could easily account for the two closed magnetic lows observed in the study area, one of which occurs over the fault intersection. 
Water. Nine chemical analyses of water samples from the study area, Group I, and eight analyses of samples from Wickenburg, Group II, are presented in Table 2. Cation ratios, chemical geothermometers and measured temperatures are presented in Table 3. Sample locations are shown in Figure 12. The data are used to provide a chemical characterization of the waters and to estimate aquifer temperatures at depth.

For comparison of the Group I and Group II samples, the major ions of 13 samples, for which complete analyses are available, are plotted on a Piper diagram (Piper, 1944) (Fig. 13). Two distinct chemical trends representing the Hassayampa and Wickenburg samples, and three anomalous analyses, can be identified on the diagram. Most Group I samples (nos. 2, 3, 8 and 9) are characterized by sodium, bicarbonate water, whereas all Group II samples (nos. 11 , 12, 13, 14 and 17) and sample 7 from Group I are characterized by sodium, calcium, bicarbonate water. Samples 5, 6 and 10 are each distinct in chemical composition, and represent waters from separate sources or waters of mixed origin.

Anomalous concentrations of certain elemental constituents and anomalous elemental ratios in water and soli samples can be inferred to indicate qualitatively a hightemperature system that has no surface expression of 
TABLE 2. CHEMICAL ANALYSES OF WATER FROM SELECTED WELLS IN THE WICKENBURG AND NORTHERN HASSAYAMPA AREA, ARIZONA

(Chemical constituents in milligrams per 1iter)

\begin{tabular}{|c|c|c|c|c|c|c|c|c|c|c|c|c|c|}
\hline $\begin{array}{c}\text { Sample } \\
\text { No. }\end{array}$ & Location & $\mathrm{pH}$ & $\mathrm{Na}$ & $\mathbf{K}$ & $\mathrm{Ca}$ & $\mathrm{Mg}$ & $\mathrm{SiO}_{2}$ & $\mathrm{Cl}$ & $\mathrm{SO}_{4}$ & $\mathrm{HCO}_{3}$ & F & B & TDS \\
\hline 1 & $B-4-5 \quad 5 A B B$ & 7.2 & \multicolumn{2}{|c|}{87} & 37 & 19.0 & 30 & 118 & 64 & 146 & 1.8 & - & 431 \\
\hline 2 & $B-4-5 \quad 18 D C C$ & 7.1 & 69 & 2.1 & 13 & 4.1 & 22 & 18 & 22 & 190 & 1.9 & 0.14 & 246 \\
\hline 3 & $B-4-5 \quad 18 D C B$ & $8.1^{\star}$ & 35 & 2.3 & 11 & 3.8 & 16 & 21 & 35 & 143 & 2.3 & 0.65 & 260 \\
\hline 4 & $\mathrm{~B}-5-5 \quad 22 \mathrm{BCC}$ & - & \multicolumn{2}{|c|}{133} & 16 & 2.0 & 28 & 94 & 38 & 185 & 2.6 & - & 413 \\
\hline 5 & $B-5-6 \quad 25 B C C$ & 6.2 & 220 & 9.5 & 121 & 0.8 & 12.7 & 440 & 105 & 60 & 4.0 & - & 1101 \\
\hline 6 & $\mathrm{~B}-5-6 \quad 31 \mathrm{ADD}$ & $8.2^{\star}$ & 9 & 1.4 & 56 & 13.1 & 34 & 24 & 7.8 & 249 & 0.5 & 0.74 & 390 \\
\hline 7 & $B-5-7 \quad 10 D D B$ & $8.3^{\star}$ & 25 & 1.9 & 14 & 5.4 & 29 & 18 & 6.2 & 138 & 0.6 & 0.67 & 250 \\
\hline 8 & $\mathrm{~B}-5-7 \quad 22 \mathrm{DBD}$ & 6.9 & 55 & 12.0 & 24 & 6.2 & 43 & 12 & 10 & 220 & 1.0 & 0.12 & 272 \\
\hline 9 & $B-6-5 \quad 31 B C C$ & 7.7 & 77 & 1.6 & 25 & 10.0 & 23 & 27 & 19 & 250 & 3.2 & 0.18 & 309 \\
\hline 10 & $B-7-4 \quad 7 C D C-3$ & 7.2 & 220 & 2.6 & 130 & 110.0 & 37 & 280 & 400 & 300 & 1.9 & 0.54 & 1330 \\
\hline 11 & $B-7-4 \quad 7 D C C$ & 7.0 & 53 & 2.8 & 59 & 16.0 & 31 & 28 & 53 & 280 & 1.5 & 0.13 & 382 \\
\hline 12 & $B-7-4 \quad 17 A A A$ & 7.7 & 35 & 3.8 & 32 & 14.0 & 43 & 23 & 9.3 & 200 & 1.0 & 0.07 & 260 \\
\hline 13 & $\mathrm{~B}-7-4 \quad 18 \mathrm{ACA}-1$ & 7.1 & 47 & 2.7 & 76 & 23.0 & 29 & 32 & 74 & 320 & 0.8 & 0.14 & 442 \\
\hline 14 & $\mathrm{~B}-7-4 \quad 20 \mathrm{CAA}$ & 6.8 & 46 & 2.7 & 70 & 21.0 & 30 & 28 & 59 & 300 & 0.8 & 0.14 & 406 \\
\hline 15 & $B-7-5 \quad 1 C C B$ & - & \multicolumn{2}{|c|}{46} & 49 & 16.0 & - & 18 & 30 & 273 & 0.8 & - & 304 \\
\hline 16 & $\mathrm{~B}-7-5 \quad 1 \mathrm{CDB}$ & - & \multicolumn{2}{|c|}{36} & 51 & 15.0 & - & 15 & 43 & 241 & 0.4 & - & 282 \\
\hline 17 & $B-7-5 \quad 21 A B C$ & 6.9 & 30 & 4.5 & 40 & 9.2 & 38 & 20 & 14 & 180 & 2.1 & 0.09 & 247 \\
\hline
\end{tabular}




\section{TABLE 3:}

$T_{1}=$ Silica temperatures assuming quartz equilibrium and conductive cooling.

$\mathrm{T}_{2}=$ Silica temperatures assuming equilibrium with $\alpha$-cristobalite

$\mathrm{T}_{3}=$ Silica temperatures assuming equilibrium with chalcedony.

$\mathbf{T}_{4}=\mathrm{Na}-\mathrm{K}-\mathrm{Ca}$ temperatures. 


\section{TABLE 3:}

$\mathrm{T}_{1}=$ Silica temperatures assuming quartz equilibrium and conductive cooling. $\mathrm{T}_{2}=\begin{aligned} & \text { Silica temperatures assuming equilibrium with } \\ & \alpha \text {-cristobalite. }\end{aligned}$ $\mathrm{T}_{3}=\begin{aligned} & \text { Silica temperatures assuming equilibrium with } \\ & \text { chalcedony. }\end{aligned}$

$\mathrm{T}_{4}=\mathrm{Na}-\mathrm{K}-\mathrm{Ca}$ temperatures. 
TABLE 3. RATIOS OF SELECTED CHEMICAL CONSTITUENTS AND ESTIMATED AQUIFER TEMPERATURES

(Chemical constituents in milligrams per liter. Chemical geothermometers in ${ }^{\mathrm{C} . \text { ) }}$

\begin{tabular}{|c|c|c|c|c|c|c|c|c|c|c|}
\hline $\begin{array}{c}\text { Sample } \\
\text { No.* }\end{array}$ & $\begin{array}{r}\text { Measured } \\
\text { Temperature }\end{array}$ & $\mathrm{C} 1 / \mathrm{F}$ & $\mathrm{C} 1 / \mathrm{B}$ & $\mathrm{Cl} / \mathrm{SO}_{4}$ & $\mathrm{Mg} / \mathrm{Ca}$ & $\mathrm{Mg} / \mathrm{Cl}$ & $\mathrm{T}_{1}$ & $\mathrm{~T}_{2}$ & $\mathrm{~T}_{3}$ & $\mathrm{~T}_{4}$ \\
\hline 1 & 28.5 & 65.6 & - & 0.81 & 0.51 & 0.61 & 79.4 & 48.1 & 29.6 & - \\
\hline 2 & 25.0 & 9.5 & 128.6 & 0.10 & 0.32 & 0.23 & $\underline{67.1}$ & 35.1 & 17.8 & $\underline{54.4}$ \\
\hline 3 & - & 9.1 & 32.3 & 0.15 & 0.35 & 0.18 & $\underline{55.3}$ & 22.9 & 6.5 & 53.7 \\
\hline 4 & 25.5 & 36.2 & - & 0.51 & 0.13 & 0.02 & 76.6 & 45.1 & 26.9 & - \\
\hline 5 & 51.0 & 110.0 & - & 7.33 & 0.01 & 0.002 & $\underline{47.2}$ & 14.6 & - & 66.4 \\
\hline 6 & 31.0 & 48.0 & 32.4 & 0.10 & 0.23 & 0.55 & 84.6 & 53.6 & 34.7 & 5.0 \\
\hline 7 & 34.0 & 30.0 & 26.9 & 0.13 & 0.39 & 0.30 & 78.0 & $\underline{46.6}$ & 28.3 & $\underline{41.2}$ \\
\hline 8 & 25.5 & 12.0 & 100.0 & 0.06 & 0.26 & 0.52 & 94.9 & 64.5 & 44.7 & $73.3^{* x}$ \\
\hline 9 & 28.5 & 8.4 & 150.0 & 0.11 & 0.40 & 0.37 & 68.8 & 36.9 & 19.4 & 36.4 \\
\hline 10 & 22.5 & 147.4 & 518.5 & 0.93 & 0.85 & 0.39 & 88.3 & 57.4 & $\underline{38.2}$ & $\underline{29.9}$ \\
\hline 11 & 22.0 & 18.7 & 215.4 & 0.10 & 0.27 & 0.57 & 80.8 & 49.5 & 30.1 & 34.2 \\
\hline 12 & 27.5 & 23.0 & 328.6 & 0.12 & 0.44 & 0.61 & 94.9 & 64.5 & 44.7 & 48.0 \\
\hline 13 & 23.5 & 40.0 & 228.6 & 0.10 & 0.30 & 0.72 & 78.0 & 46.6 & $\underline{28} .3$ & 27.1 \\
\hline 14 & 21.0 & 35.0 & 200.0 & 0.09 & 0.30 & 0.75 & 79.4 & 48.1 & 29.6 & 28.2 \\
\hline 15 & - & 22.5 & - & 0.07 & 0.33 & 0.89 & - & - & - & - \\
\hline 16 & - & 37.5 & - & 0.06 & 0.29 & 1.00 & - & - & - & - \\
\hline 17 & 26.0 & 9.5 & 222.2 & 0.11 & & 0.46 & 58.7 & 58.7 & 39.3 & 47.1 \\
\hline
\end{tabular}

** See Table 2 for locations.

A Mg correction applied to sample 8 yields this value. Other samples did not require a Mg correctior 


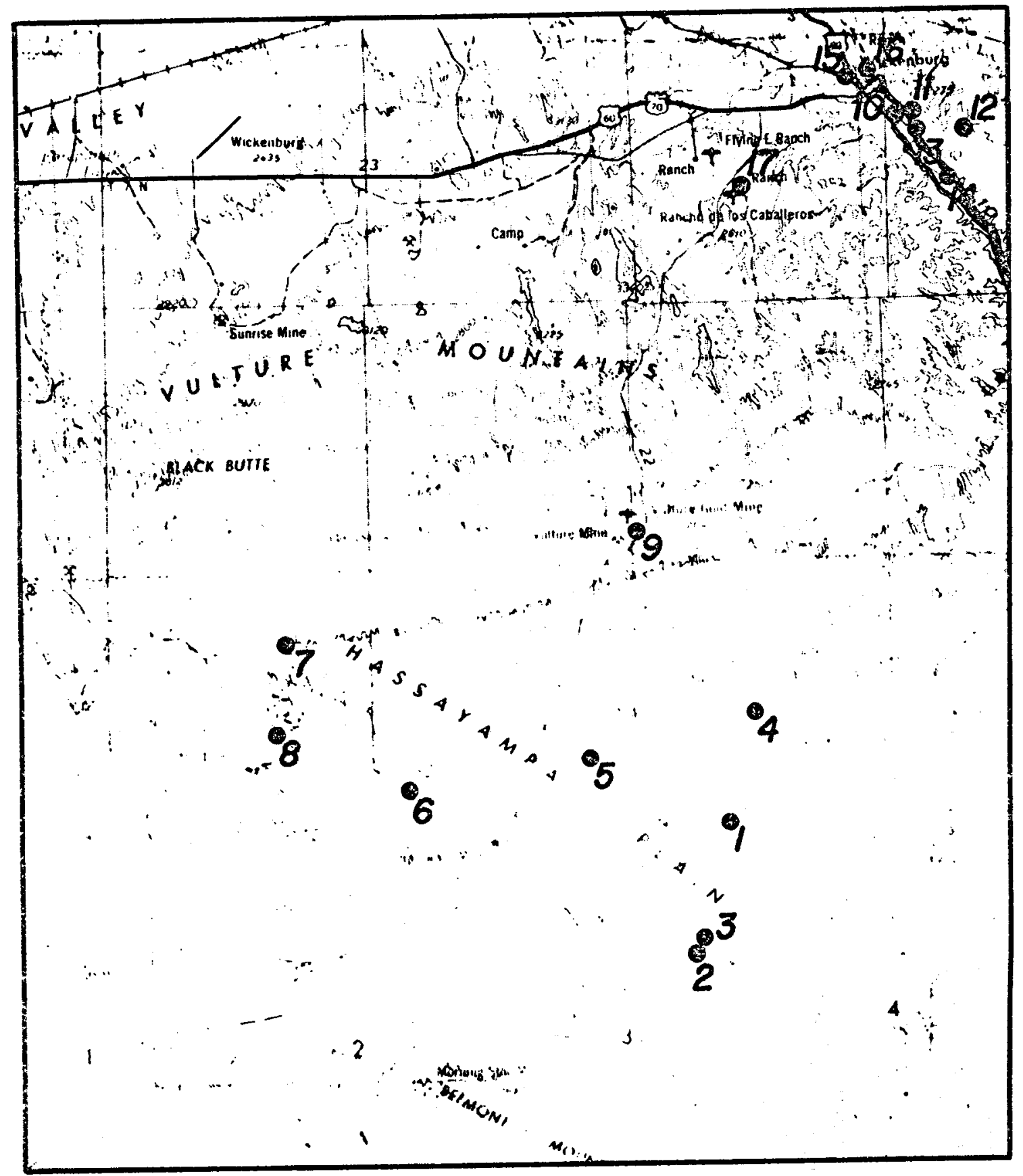

Figure 12. Locations of Water Samples. 


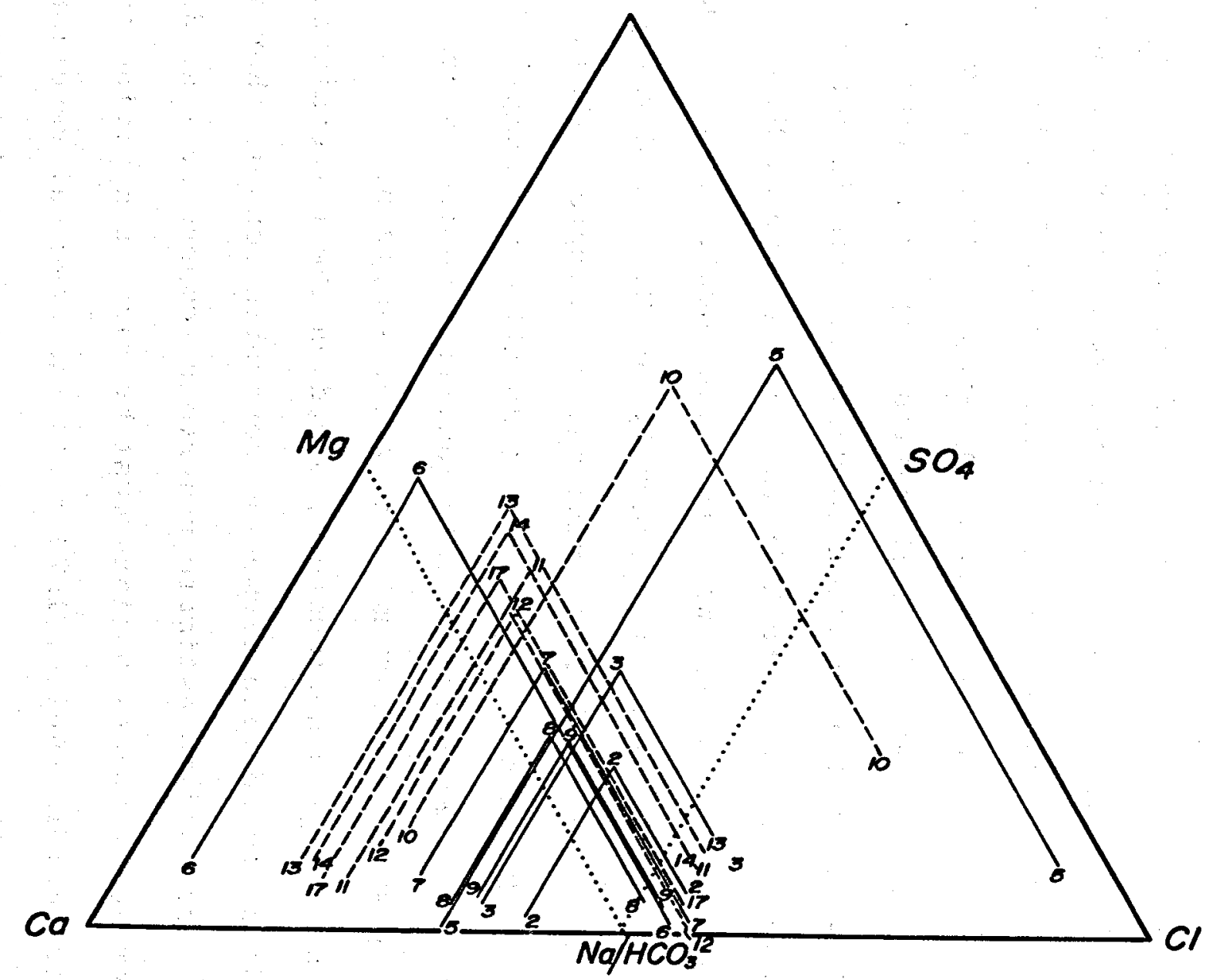

Figure 13. Piper Diagram showing chemical distinction between Group I (Hassayampa) water samples (solid lines) and Group II (Wickenburg) water samples (dashed lines). 
thermal water. Mahon (1970) showed that high Cl/F and $\mathrm{Cl}_{4} \mathrm{So}_{4}$ ratios in a geothermal area Eenerally indicate high temperature in the system. Sample 5 has high ralues for both ratios; sample 10 has a high $C l / F$ ratio (Table 3 ). The $C I / B$ and $C I / F$ ratios for Group II samples (except sample 10) are very similar, supporting the inference that those waters are from the same aquifer and are distinct from Group I samples. The same inference with respect to source cannot be made from the Group $I C I / F$ and $C l / B$ ratios, as the Group I Cl/F ratios vary among samples by a factor greater than 7.5 and the $C l / B$ ratios vary by a factor of 6 . Hydrothermal alteration commonly results in uptake of magnesium by the wall rock in the manufacture of $\mathrm{Mg}$-chlorite and Mg-montmorilionite, with resultant depletion of magnesium in the thermal water. Consequently low $\mathrm{Mg} / \mathrm{Ca}$ and $\mathrm{Mg} / \mathrm{Cl}$ ratios also may reflect thermal water. Sample 5 shows ratios of $\mathrm{Mg} / \mathrm{Ca}$ and $\mathrm{Mg} / \mathrm{Cl}$ lower than all other samples by two orders of magnitude. These qualitative indicators strongly suggest a thermal origin for sample 5 .

Chemical geothermometers, based on the temperature dependence to certain elemental concentrations in thermal water, are used to estimate reservoir temperatures at depth. However, certain assumptions must be made in applying the geothermometers (White, 1970): 1) the chemical reactions controlling the amount of a chemical constituent taken into solution by hot water are temperature dependent, 2) an adequate supply of these chemical constituents is present 
in the aquifer, 3) chemical equilibrium has been established between the hot water and the wall rocks which supply the chemical constituents, 4) hot water from the aquifer flows rapidly to the surface, and 5) the chemical composition of the hot water does not change (mix with cold water, evolve gas, or precipitate minerals) as it rises to the surface. Often these assumptions cannot be demonstrated in a field situation, so that chemical geothermometers must be used with caution. With that understanding, chemical geothermometers can provide a useful reconnaissance tool for making a preliminary estimate of reservoir temperatures at depth. There is excellent correlation between the silica and $\mathrm{Na}-\mathrm{K}-\mathrm{Ca}$ predicted aquifer temperatures for the Group II samples ( Table 3 ), the best agreement occurring between $\mathrm{Na}-\mathrm{K}-\mathrm{Ca}$ and $\alpha$-cristobalite, rather than with chalcedony as is commonly found with most Arizona Basin and Range water samples. This would be a result of host rock mineralogic composition. There is an equally good correlation of chemical geothermometers anong the individual water samples from Group II. The Group II samples predict an aquifer temperature of about $35^{\circ} \mathrm{C}$ in the Wickenburg area. (Mean $\mathrm{T}\left(\mathrm{SiO}_{2}\right)$ is $35.0^{\circ} \mathrm{C}$; mean $\mathrm{T}(\mathrm{Na}-\mathrm{K}-\mathrm{Ca})$ is $\left.35.7^{\circ} \mathrm{C}.\right)$

Among Group I samples correlation is less distinct. For samples 7,8 , and $9, \mathrm{Na}-\mathrm{K}-\mathrm{Ca}$ agrees well with chalcedony and predicts subsurface temperatures up to $73^{\circ} \mathrm{C}$. $\mathrm{Na}-\mathrm{K}-\mathrm{Ca}$ of samples 2 and 3 correlates with conductive quartz and 


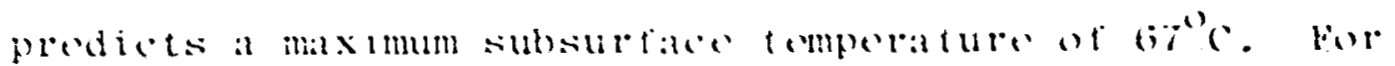
sample 5, the silica feothermometer is loller than lhe measured temporature which might be cxplatued in sereral ways: (1) the analysis could be in erere, (2) some procipitation of silica could have oceured, lowering the silica concentration in tho water, or (3) the themal water could be slifhtly mixed with oold water, also lowering the silica concentration. It this last cxplanation is correct, it would lend support to the sugresition that all waters in the study area are of mixed origin; that is. thermal water from depth is mixing to various degrees with shallow cold water. The chemical freothermometers aro therefore predicting lower subsurface temperatures than actualiy exist. Mixing model calculations will resolve this problem when sufficiont data are available.

An interesting feature of the water chomistry is the apparent distinction among the Group I samples which may be related to structural control. Samples $6,7,8$, and 9 wero collocted northwest of the northoast-tronding fault (rigs. 2 and 12), and samples 2 and 3 were collected southeast of the fault. Samples 5 and 6 , which yield anomalous chemical analyses, orifinate nearest tho lault intersection. Furthermore, the lowest predicted temperature, $36.9^{\circ} \mathrm{c}$, is lrom sample 9 , which is located larthest from the latult inlersection (Fig. 11).

Soil. Soil samples were collected at saction and quarter-section corners over $150 \mathrm{~km}^{2}$ lor morcury analysis. 
Mean value of $\mathrm{Hg}$ for the sampled area is 25 parts per billion $(p p b)$. Values greater than 25 ppb are distinguished in Figure 7 by larger numerals. Three trends, closely following the structural trends outlined by the other surveys, are apparent. The higher Hg values imply leakage of mercury along the faults. However, mercury anomalies often mark fossil (now cold) thermal systems and consequently, they too must be viewed with caution.

\section{SUMMARY AND CONCLUSIONS}

The northern Hassayampa $\mathrm{Plain}$ is a broad, sedimentfilled basin with a complexly faulted basement. Depth to bedrock depends upon the degree of rotation and displacement of basement blocks and probably ranges from shallow to many hundreds of meters.

The three distinct structural trends (NE, NNW, and NW) identified from air photo interpretation, Landsat lineaments and geochemical trends are here interpreted as fault traces. Two of these inferred faults (NE and NNW) agree with the strike maxima identified in the Vulture Mountains by Rehrig and Heidrick (1976).

The measured geothermal gradients define a single discrete area of hydrologic discharge that is about $30 \mathrm{~km}^{2}$ and can best be explained as reing fault controlled. The three wells that constrain the area are adjacent to one another and are the wells located nearest the faults and the fault intersection. The maximum reported water temperature in the study area, $53^{\circ} \mathrm{C}$, is from well A (Fig. 11) which yields 
an anomalous chemical analysis, sample 5, and has the highest geothermal gradient, $140^{\circ} \mathrm{C} / \mathrm{km}$. It seems likely that the water in this well is rising from a deep thermal source along fault planes and fractures. The origin of other waters is uncertain, but may represent waters from the same source, mixed to a greater degree with cold water. The maximum temperature of $73^{\circ} \mathrm{C}$ predicted by geochemical methods probably represents a minimum subsurface temperature and is too low as a result of not satisfying the necessary assumptions. Mixing of hot water rising from the deep subsurface, with water in a shallow, cold aquifer, can distort measured temperatures, chemical geothermometers, and geothermal gradients.

Although a reliable estimate of the geothermal potential of the northern Hassayampa Plain cannot be made because of insufficient data, certain trends have been identified that strongly suggest the presence of a geothermal resource that is primarily controlled by intersection of the principal zones of faulting. Maximum temperature and reservoir volume cannot be predicted without detailed geologic and geophysical surveys, and deey drilling. Recommendations are made for additional field investigations, in order of priority, which should substantially assist in evaluating this geothermal anomaly. 
1. Detailed geologic mapping of the Belmont lountains and the area to the northwest thereof, with rock chemical analyses and age dates as necessary, to understand the geologic setting of the geothermal reservoir.

2. Detailed gravity survey over the inferred faults and fault intersection, to determine subsurface structures and depths to bedrock.

3. Shallow drill holes $(50 \mathrm{~m})$ across the faults and the fault intersection, to determine possible zones of high heat flow.

4. Electrical resistivity survey, to identify zones of and depths to thermal waters in the deep subsurface.

5. Exhaustive water sampling with complete chemical and isotopic analyses, to identify and characterize the deep and shallow aquifers, and to provide enough samples to determine if mixing of hot and cold waters is occurring. Mixing model calculation will more accurately determine subsurface temperature. 


\section{BIBLIOGRAPHY}

Batzle, M. L. and Simmons, G., 1977, Assessing geothermal areas during drilling. Geothermal Resources Council, Transactions, Vol. 1, p. 13-15.

Blackwe11, D. D., and Chapman, D. S., 1977, Interpretation of geothermal gradient and heat flow data for Basin and Range geothermal systems. Geothermal Resources Council, Transactions, Vol. 1, p. 19-20.

Chapman, D. S., Yilty, K. T., and Mase, C. W., 1979, Temperatures and their dependence on groundwater flow in shallow geothermal systems. Geothermal Resources Council, Transactions, Vol. 2, p. 79-81.

FUGRo, 1979, Personal communication.

Hahman, W. R., Sr., 1979, Geothermal energy in Arizona. Geothermal Energy, in press.

Hutchinson, W. S., 1921, The Vulture Mine. Engineering and Mining Journal, Vol. III, No. 7, p. 298-302.

Lepley, L. K., 1978, Landsat lineament map of Arizona with emphasis on Quaternary features. in Low Temperature Geothermal Reservoir Site Evaluation in Arizona, Quarterly progress Report for Period February 1, 1978April 30, 1978. Bureau of Geology and Mineral Technology, Tueson, Arizona, p. 63-91.

Lysonski, J. and Sumner, J. S., 1979, Terraine Corrected Residual Bouguer Gravity Map of Arizona, unpublished data.

Mahon, W. A. J., 1970, Chemistry in the exploration and exploitation of hydrothermal systems. in Proceedings United Nations Symp. on the Deveiopment and Utilization of Geothermal Energy: Pisa, Vo1. 2, Part 2, Geothermics, Spec. Issue 2, p. 1310-1322.

NOAA, 1973, Monthly normals oi temperature, precipitation and heating and cooling aegree days 1941-1970. National Climatic Center, Asheville, N. C.

Piper, A. M., 1944, A graphic procedure in the geochemical interpretation of water analyses. Transactions, American Geophysical Union, Papers in Hydrology, p. 914-923. 
Rehrig, W. A., Shafiquiiah, If, and Damon, P. E., 1979, Geochronoiogy and geology of the luiture llountains, Maricopa County, Arizona. Arizona Geological Society Digest, Vol. 12, in press.

Rehrig, W. A. and Heidrick, T. L., 1976, Regional tectonic stress during Laramide and late Tertiary intrusive periods, Basin and Range province, Arizona. Arizona Geological Society Digest, Vol. io, p. 205-228.

Sauck, H. A. and Sumner, J. S., 1970, Residual Aeromagnetic Map of Arizona. Department of Geosciences, University of Arizona, Tucson, Arizona, 1:1,000,000 scale.

White, D. E., 1970, Geochemistry applied to the discovery, evaluation, and exploitation of geothermal energy resources. 'in Proceedings United Nations Symp. on the Development and Utilization of Geothermal Energy: Pisa, Vol. 1, Part 2, Geothermics, Spec. Issue 2, p. 58-80.

Wilson, Moore, and Cooper, 1969, Geologic Map of Arizona. 
GEOTHERMAL ENERGY IN ARIZONA

W. Richard Hahman, Sr.

\section{ABSTRACT}

The Bureau of Geology and Mineral Technology, Geological Survey Branch, using federal funds, has been exploring for geothermal energy since May, 1977. The known major geothermal systems in Arizona are apparently caused by deep circulation of meteoric water through the complex fracture systems of the Basin and Range region and transition zone. This type of system is thought to be capable of generating geothermal reservoirs with temperatures on the order of $150^{\circ} \mathrm{C}-200^{\circ} \mathrm{C}$ at 2-3 $\mathrm{km}$ depth in the intermontane basin.

\section{INTRODUCTION}

Geothermal energy in Arizona was probably first used by the Indians who recognized the therapeutic value of the warm and hot springs. With the arrival of the white man the spa industry developed and still flourishes today in Maricopa and Graham counties.

In the early 1970 's Geothermal Kinetics, Inc., and AMAX Exploration, Inc., conducted exploration programs for geothermal energy in the state. The drilling that resulted from these programs, while providing significant geological data, was not productive from an energy standpoint. 
In May, 1977, the Arizona 3ureau of Geology and Minerai Technology, Geological Survey Branch, with funding for low-to moderate-temperature resource assessment from the U.S. Department of Energy, Division of Gecthermal Energy, commenced its current exploration program for geothermal energy. The program was initiated in response to prior geothermal research and reconnaissance programs conducted primarily uncier the aegis of the federal government. The initial program was extremely iimited in areal extent but expanded rapidiy to include the entire state of Arizona. In 1978, the J.S. Department oi the interior, Bureau of Reciamation, became a participant in the program. The Bureau of Reclamation wishes to utilize geothermal energy as the power source for desalination of brines to augment Arizora's municipai and industriai water supply.

This paper presents some of the results of the exploration and evaluation program for geothermal energy in Arizona.

\section{DISCUSSION}

Regional Geology of Arizona

The state of Arizona may be divided into two physiographic provinces: the Coiorado Plateau in the northeast part of the state, and the Basin and Range Province in tre southwest part of the state (Pigure 1 ). There is a transition zone between che rwo provinces. The complex iithologies and overall structure of the Basin and Range province are the resuit of a long 


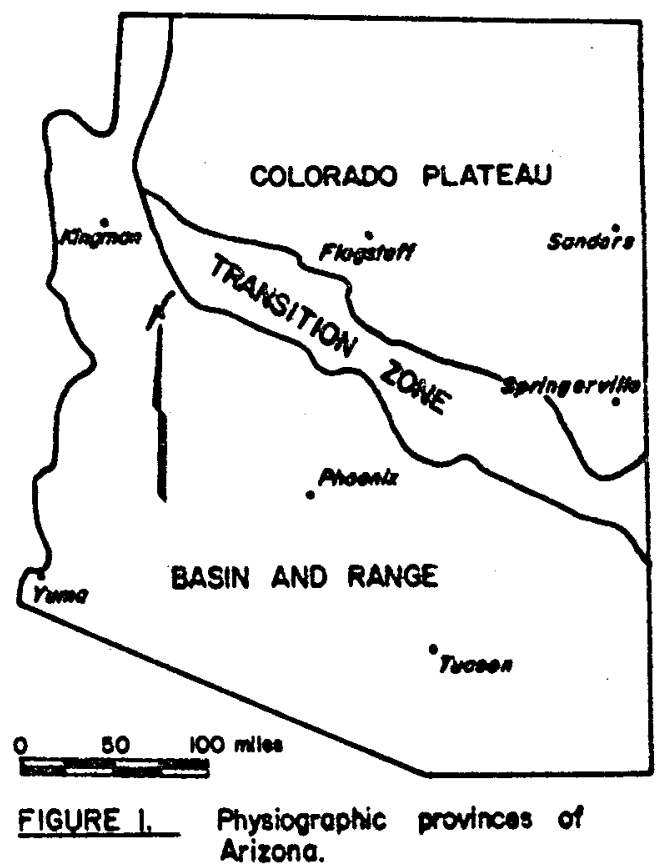


nistory of tectonic activity that commenced auring Precambrian times, over.i.5 billion years ago. The physical ieatures visible today, such as north ana northwest trending mountain ranges and sediment-filled intermontane basins, are largely the result of complex tectonic activity, predominantly regionai extension, that commences approximately 14 milion years ago and may continue in some places.

The Colorado Piateau, compared to the Basin and Range province, has been tectorically stable. The land forms that characterize this province are deep canyons, broad plains, piateaus, buttes and mesas. These features have been formed by differential erosion of resistant and nonresistant sedimentary rocks.

\section{Regional Geothermal Characteristics}

Lachenoruch and Sass (i977, Figures 2 and 3, pages 629 and 630) give a regional heat flow for the Arizona Basin and Range region of 1.5 to 2.5 heat flow units. A heat flow unit (HFC) is derined as $10^{-6}$ calories $/ \mathrm{cm}^{2} /$ second, or $41.8 \mathrm{~mW} / \mathrm{m}^{2}$. It is the measure used to describe the outward flow of heat from tae earth over a given area during an eiapsed time. The same althors give a regional seat flow for the Colorado plateau of Arizona of 0.75 to $1.5 \mathrm{HFU}$. Since the Basin and Rarge province has considerably higher heat flow than the Colorado piateau, it follows that grouncwater in the Basin and Range province has a greater temperiture than grourdwater of the Colorado Piateau. 
swanherg. Morgan, Stoyer and Witcher (1977. Figure 9. Pagc :0) usod woll and spring tomperaturs data from the U.S. Geolonical Survey water quality file to caleulate monn water temperature values for the colorado plateau, 16.100 , and for the Basin and Range province, $26.2^{\circ} \mathrm{C}$. The surface temperature of Colorado plateau groundwater approximates the $15^{\circ} \mathrm{C}$ (Gorach, Norton, DeCook and Sumner, 1975) mean annual air temperature of that region. There is no similar correlation found in the Basin and hango province where the mean annual air temperature is $21^{\circ} \mathrm{C}$ (Gerlach and others, 1975). This lack of correlation confirms the occurrence of higher heat flow in the Basin and Range region.

The paucity of known thermal springs and wells, especially wells, in the Arizona section of the Colorado plateau could be the result of lack of observation; however, it most likely is the result of the plateau's relatively low heat flow.

The background thermal gradient for the Basin and Range province in Arizona is $30^{\circ} \mathrm{C}$ to $35^{\circ} \mathrm{C} / \mathrm{km}$. Current work indicates that a gradient greater than $48^{\circ} \mathrm{C} / \mathrm{km}$ may be indicative of geothermal water in Arizona (Swanberg, personal communication, Apri1, 1979).

\section{Table 1. MLASURED THERMAL GRADIENTS - ARIZONA}

Colorado Plateau

Nutrioso

$510 \mathrm{C} / \mathrm{km}$

$53^{\circ} \mathrm{C} / \mathrm{km}$ 
Basin and Range Province

$\begin{array}{lr}\text { Papago Indian Reservation } & 136^{\circ} \mathrm{C} / \mathrm{km} \\ \text { Hassayampa Plain } & 160^{\circ} \mathrm{C} / \mathrm{km} \\ & 112 \mathrm{C}^{\circ} / \mathrm{km} \\ & 86^{\circ} \mathrm{C} / \mathrm{km}\end{array}$

Widely used in geothermal exploration is the theoretical relationship between water chemistry and the temperature in the originating reservoir. The silica geothermometer (Fournier and Rowe, 1966) is probably the most accurate of the water chemistry geothermometers. This geothermometer is based on the temperature dependence of quartz solubility in water. Swanberg and others (1977) estimated that the minimum temperatures for the silica geothermometer are $30^{\circ}$ to $40^{\circ} \mathrm{C} \mathrm{higher}$ for waters from the Basin and Range province than for waters from the Colorado Plateau. The higher temperatures for the Basin and Range province probably result from the higher heat flow and the deep circulation of groundwater in the alluvium-fillea basins.

With the possible exceptions of the San Francisco Peaks, Springerville, San Bernardino and Pinnacate areas, Arizona does not have any obvious igneous point source geothermal energy. Heat is supplied to the igneous point source system * by a near-surface, igneous intrusive body generally of silicic composition, less than one million years old and often stiil partialiy moiten (Figure 2). Preliminary investigations by tine Geothermal Project of the Bureau of Geology and Mineral 
$\infty$

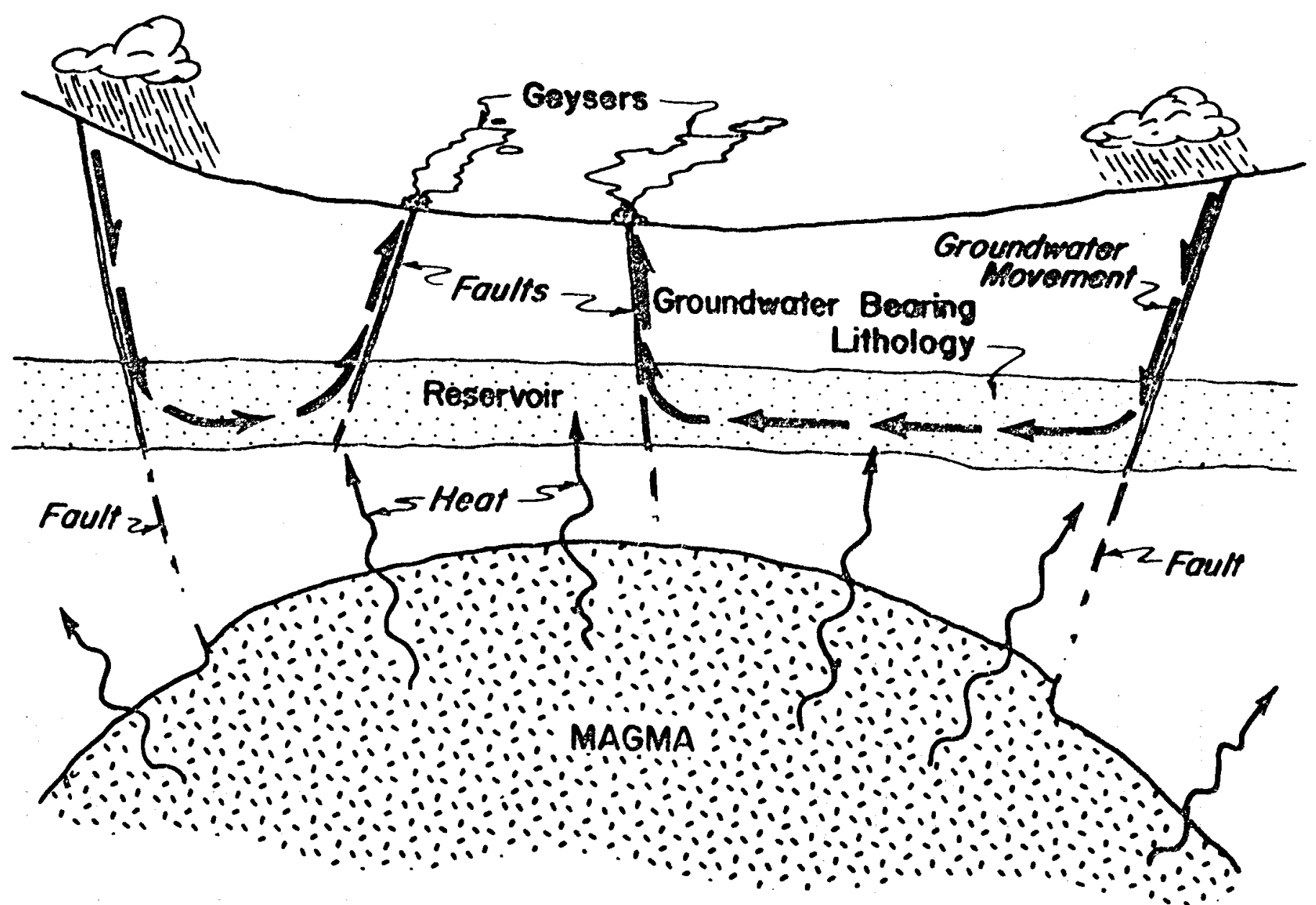

FIGURE 2. Stylized drawing of on igneous point source geothermal system. 
Technology indicate geothermai energy potential in the proximity of several of the younger basalt fields (Hahman, Sr., Stone and Witcher, 1978) 3 m.y.B.P. and younger in Arizona. Whether exploitable geothermal energy will be located in proximity to any or all of the Quarternary basalt fields is not known at present. Whether there is a direct cause and effect relationship between the young basalts and the geothermal energy also remains to be proved.

In Arizona, natural thermal springs and drilled wells serve as indicators of hydrothermal geothermal systems. Thermal springs and wells are widely distributed throughout the state, but are most abundant in the Basin and Range province and transition zone. Possible explanations for this relative concentration of geothermal phenomenon are itemized and then discussed in detail.

1. Deep circulation of meteoric water through intense, complex fracture systems.

2. Igneous point source intruded along fractures or zones of weakness, not exposed at the surface.

3. A combination of the prior two possibilities.

4. Heat generated by decay of radioactive elements in igneous rocks.

5. Exothermic reaction resulting from the hydration of bedded anhydrite in the evaporite sequence of sediments that occur in some of the intermontane basins. 
Investirations to date by the Geothermal project indicate that the likely explanation is deep circulation of meteoric water through the compiex network of fracture systems in the Basin and Range province and the transition zone as suggested by Chapman, Kilty and Mase (1978). This type of system is apparently capable of generating geothermal reservoirs with temperatures of $150^{\circ} \mathrm{C}$ to $200^{\circ} \mathrm{C}$ in the intermontane basins, and will be discussed in detail in a later section.

Current investigations indicate that the best chances for igneous point source geothermal energy are associated with the young, Quaternary volcanic fields scattered across the state in both the Basin and Range and Plateau provinces.

Heat generated by radioactive decay of uranium and thorium mineralization in buried Precambrian granites will probably make a significant contribution to geothermal energy in Arizona. A conservative guesstimate is that there are many cubic miles of buried Precambrain granite in Arizona, and a situation similar to the Conway granite of North and South Carolina with its anomalously higher concentrations of radioactive elements should be expected. Reiter and Shearer (1979, in press) have determined an area of high heat flow 2.6 and $3.8 \mathrm{HFU}$, just south of Sanders, Arizona. Hahman, Sr., and others (1978) show several anomalous areas in northeastern Arizona. Quite possibly these geothermally anomalous areas are the result of heat generated by radioactive decay of radioactive elements in basement granice. The reiatively abundant, naturally occurring radioactive elements $\mathrm{U}^{238}, \mathrm{U}^{235}$ and 
$T^{232}$ give end products of iead and heíum. Quite possibiy helium found in the Hoibrook basin is the result of radioactive decay, the helium having migrated upward into structural or stratigraphic traps in the overlying sediments. Alternate hypotheses to explain the limited areas of high heat flow in the Colorado Plateau have been posed by other investigators. Reiter, Mansure and Shearer (1978) state "that the sources of these high heat flows are associated with the volcanics of the area and their sources." Laughlin (personai communication, 1979) states that the preliminary analysis of Los Alamos Scientific Laboratory magnetotelluric data indicates the possibility of an upwelling in the mantle in the Sanders area which could explain the high heat flow.

For the Basin and Range province, it has been proposed by Gerlach and others (1975) that the exothermic reaction of anhydrite altering to gypsum in the evaporite sequences occurring in many of the intermontane basins is supplying heat for some of the geothermal resources. Exploration to date by the Geothermal Project indicates that warm water moving along faults in the basin fill is a more plausible explanation.

\section{Exploration and Evaluation Program}

Hydrothermal resources suitable for electrical generation are expected to be encountered in several areas in the state. These favorable areas have been identified (1) by geochemical thermometers indicating projected reservior temperatures as 
calcuiared from chemical anajyses of water from welis and springs and (2) by temperature logging oi waier weils and drill holes. The favorable areas are the San Bernardiro valiey, Clifton-Morenci-Safforà, Springervizle-St. JohnsAipine, Flagstaff, Phoenix and Hyder valiey areas. Adoitional expioration is expectec to locate other areas iavorabie for eicctrical generation from hydrothermal resources.

Iahman, Sr., and others (1978) show both high-temperature and low-to moderate-temperature areas on their map of Geothermai Energy Resources of Arizona. Again, it can be seen that most of the favorabie areas are situated in the Basin and Range physiographic province. Preìiminary investigations indicate that iow-to moderate-temperature geothermal energy will be available for use at most of the popuiated areas in the Arizona Basir and Range province.

The current major uses of iow-to moderate-temperature groothermai resources in Arizona are in space heating and cooling, industriai processing and agribusiness.

Arizora also has potentiai for hot ary rock geothermai energy for lise in electrical generation and direct applications.

Byeriy and Stolt (i977) deíined a broad zone through centrai Arizona where the Curie point rises to less than $10 \mathrm{~km}$ anci often less than $5 \mathrm{~km}$ Delow sea level (Figure 3 ). The Curie point, that temperature at which materials iose their r.aginetic property, is $5750^{\circ}$ for magnetite. Thereiore, if the 


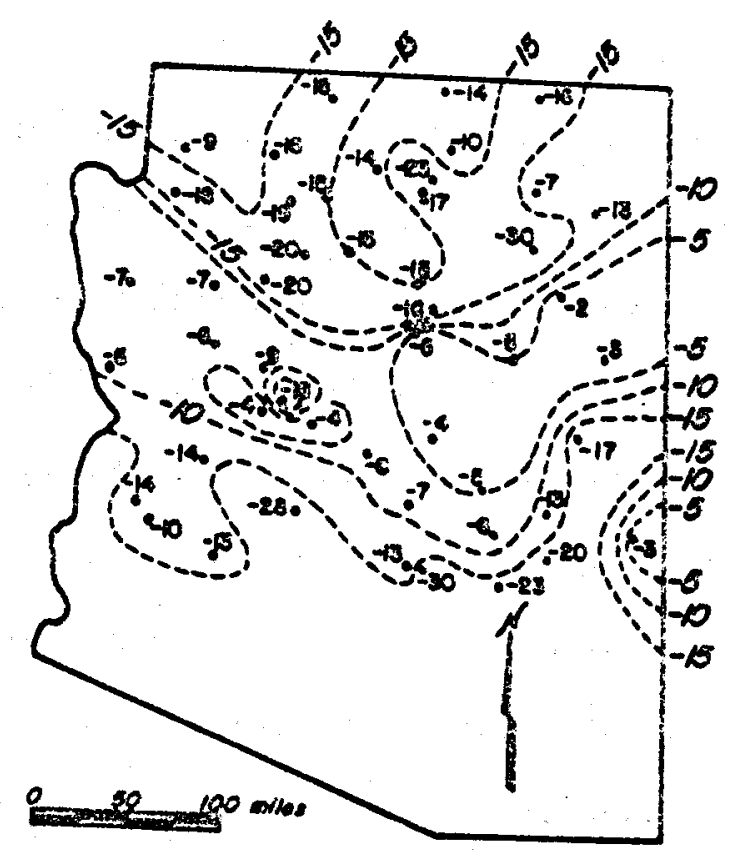

FiGURE 3. Depthe (km. te. l.) to the bose of the magnepic cruet in northera and central Arizono fofter

Eyarty and stolt, 1977). 
Curie point is at $5+\mathrm{km}$, one might reasonably expect to have a temperature of approximately $575^{\circ} \mathrm{C}$ at that depth. The zone where the Curie point is within $5+\mathrm{km}$ of the surface would be a much moie favorable zone in which to look for hot dry rock and/or hydrothermal resources associated with young, concealed, silicic, igneous intrusive rocks than a section where the Curie point is at a depth of 20 or $30 \mathrm{~km}$.

Regional exploration and reconnaissance in Arizona is continuing, with the main thrust directed toward devising an efficient, cost effective exploration, evaluation and devclopment procedure for low to moderate temperature $\left(<150^{\circ} \mathrm{C}\right)$ froutinermal energy resources. Simultaneousiy, exploration and tvajuaijon for moderate to high temperature igreater than $150^{\circ} \mathrm{C}$ ) greothermal resuales suitabie for electrical generation, including hot dry rock, is being conducted. During the course of these investigations, anomalies have been located, and site specific investigations are being conducted.

The following are summaries of the site specific investigations:

Becalise of favorable geochemical geothermometer data, the proximity of young voicanic rocks ano favorable regional lineanents intersections detemined from Landsat photography, the initial target chosen for site specific work was the springerville-si. Johns area. As work progresses, tive target area shified ت̈rom between Springerviile and St. Johns to between Siringervile and Alpine. The anomaious area (Figure 4), with 


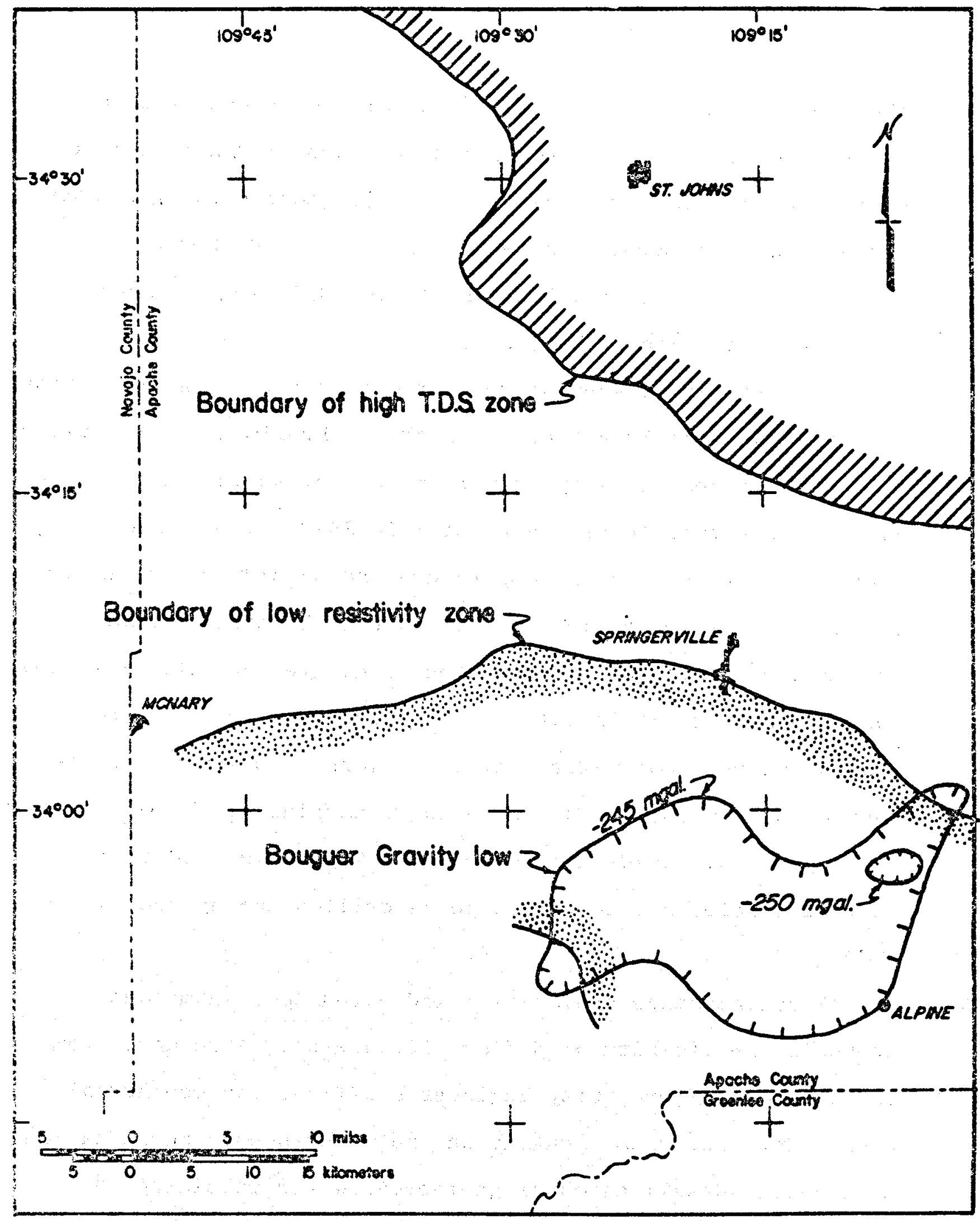

PXE 4. Groviny, resistivity, and high ID.S. in the Sprirgerville area (from Stona, 1979). 
the anomaly stili open to the southwest and extending onto the Fort Apache Indian Reservation, has been further defined by a large gravity low ( -245 milligals), geochemical geothermometers, a large anomalous resistivity low, and thermal gradient logs of water weils. Heat flow drilling to depths of 1,250 feet began in May, 1979 .

Another target area picked early in the program is Clifton and the lower San Francisco river area. Preliminary evaluations of the water geochemistry from warm and hot springs indicate minimum reservoir temperatures of $150-188^{\circ} \mathrm{C}$. The resource then is moderate-to high-temperature and should be considered for electrical generation as well as non-electrical uses. Preliminary geologic investigations indicate that the reservoir could be structural in nature. That is, the reservoir may consist of very hot water contained along a series of interconnecting faults. Detailed geologic mapping of the Clifton 15' topographic quadrangle started in May, 1979, and four heat flow holes are scheduled to be drilled during the fall of 1979.

Reconnaissance exploration indicated some anomalous areas in the vicinity of Safford (Figure 5). A request from the town of Safford, City Engineer's office, for geothermal energy for electrical generation and water supply augmentation through the desalination of geothermal water initiated the site-specific work. Results to date have defined several anomalous areas (Figure 5). Resistivity surveys, over 100 line miles, are currently being used to refine these target 


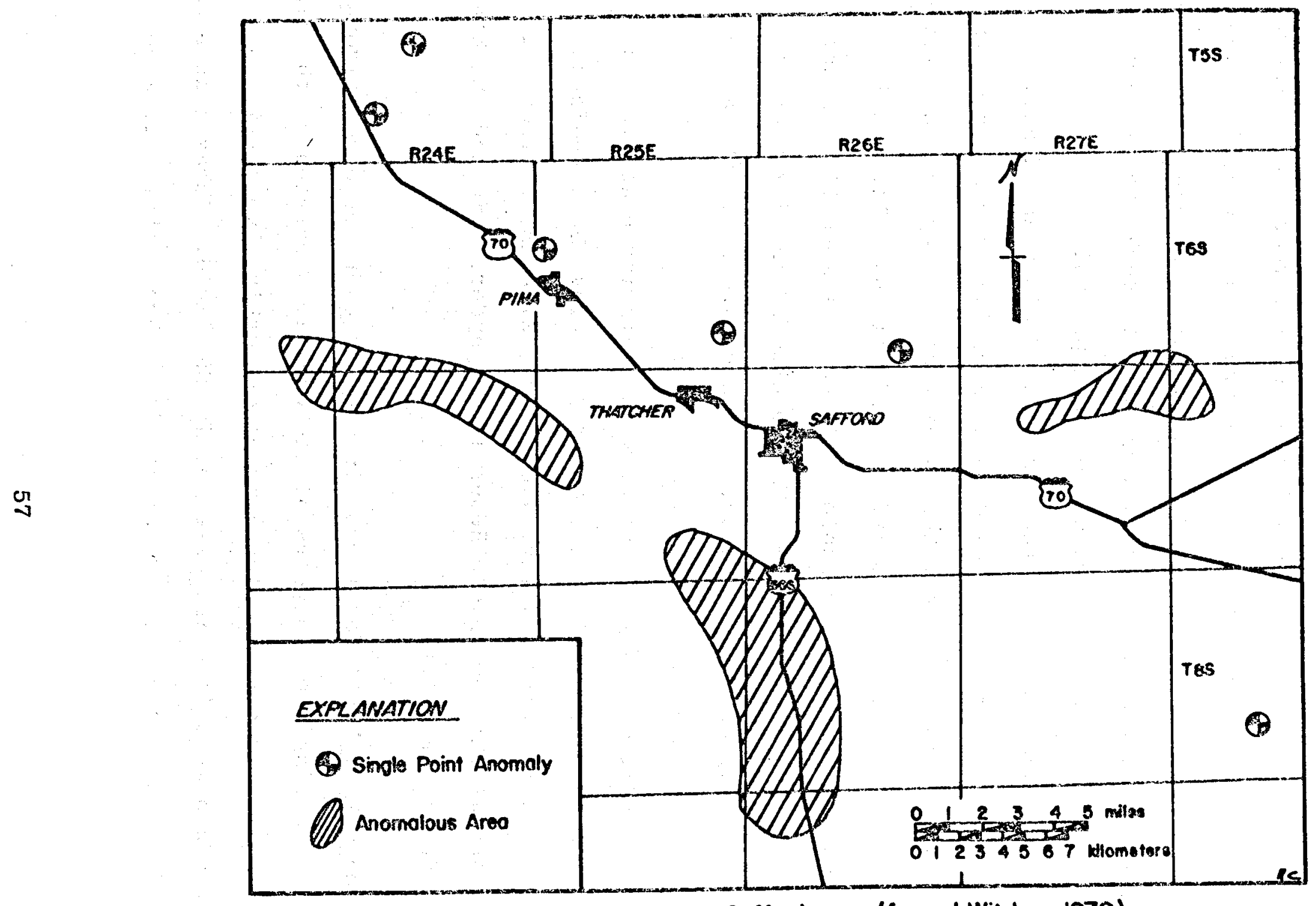

EIGURE 5. Goothermal anomalies in the Safford area (from J. Witcher, 1979). 
areas. Upon completion of this work, thermal fradient drilling is scheduied. Geochemical geothermometery, oil-well test bottom-hole temperatures and water-well temperature gradients indicate temperatures of $50-120^{\circ} \mathrm{C}$ are to be expected at depths to $1 \mathrm{~km}$; nowever, assuming a normal Basin and Range temperature gradient gives reason to believe that temperatures in excess of $150^{\circ} \mathrm{C}$ may be expected at depths approaching $2 \mathrm{~km}$.

At the request of the Bureau of Geology and Mineral Techhology, Geological Survey Branch, a preliminary study of the Tucson basin was undertaken as part of a study for the Office of Arid Land Studies, University of Arizona. The initial results have been favorable, and the site specific evaluation is continuing (Figure 6). The results of the Exxon drilling in the Tucson basin indicate hot water around $150^{\circ} \mathrm{C}$ may be expected at depths of $3 \mathrm{~km}$.

Additional site-specific work is taking place in the following areas: Phoenix, Chandler-Higley, Buckeye-TonopahHassayampa, Verde valley, Wickenburg, Kingman, Willcox, Papago Reservation, Fort Apache Reservation, Hyder, Yuma and the San Pedro river valley.

Geothermal Model for the Basin and Range Province of Arizona

During the two years of the program's existence, the staff has attempted to develop a model or working hypothesis to. explain what is being observed in the field. Ideas change as adcitional data are generated. It is hoped that this model or 


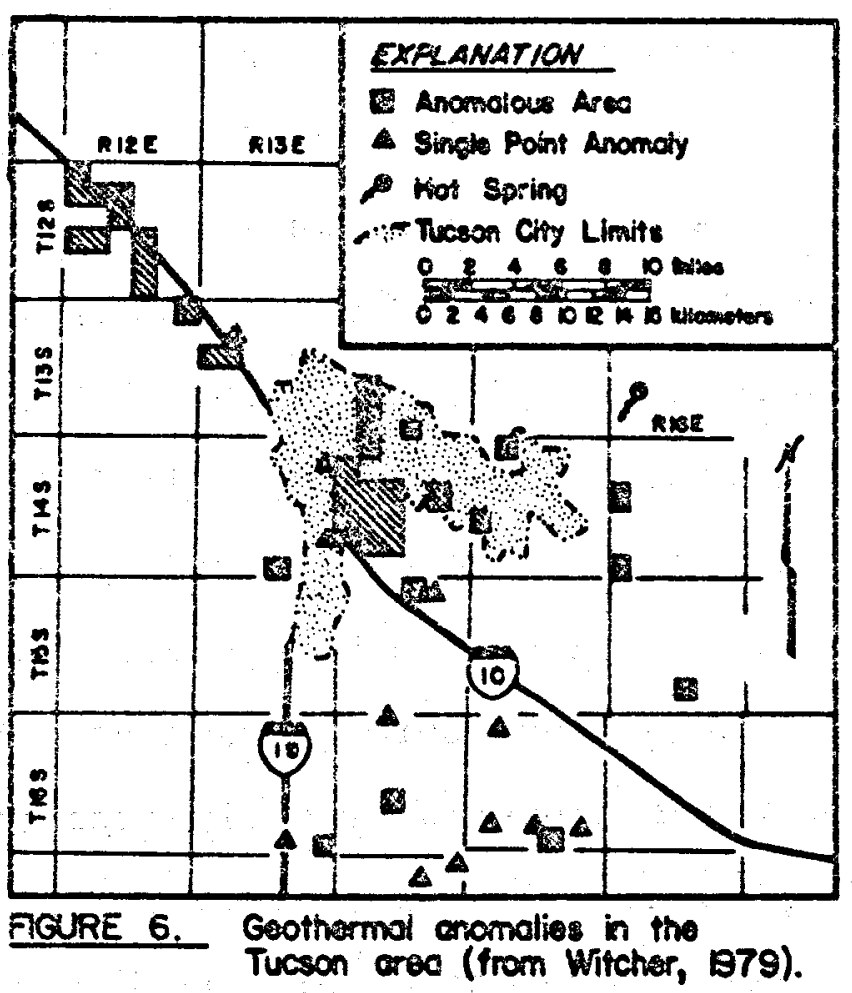


a future modification is correct; however, the only requirement is that this model work as an exploration tool. It is not important that the geothermal energy is found for the "right" or "wrong" reasons; it is very important that the geothermal energy is found.

Eberly and Stanley, Jr. (1978) in a study of the Cenozoic stratigraphy and geologic history of southwestern Arizona divided the basin lithologies into an older Unit $I$ and a younger Unit II. The sediments of early Cenozoic Unit I time were continental deposits laid down in broad depressions. The sediments of late Cenozoic Unit II time, agair primarily continontal deposits, were laid down in troughs or grabens created by the Basin and Range disturbance that commenced approximately 20 m.y.B.P. (Loring, 1976). Eberly and Stanley found a major unconformity separating Unit I from Unit II.

In the initial assessment of the geothermal potential for the Basin and Range province, (Hahman, Sr., and others, 1978) the large difference between normal gradient, $35^{\circ} \mathrm{C} / \mathrm{km}$, and gradients in anomalous areas was readily apparent, as was the association of anomalies with Landsat lineaments and lineament intersections. Also, some deeper oil and water wells encounterd very high gradients at the bottom, not reflected in the upper part of the hole. These temperatures, $150-200^{\circ} \mathrm{C}$ within depths of 2-3 km, are of considerable practical interest. But the questions remained, "What, or where is the source of the heat and how do these systems work?" There is no real geophysical 
evidence for mantle plumes or upwellings in Arizona, nor is there significant geological nor geophysical evidence for siilicic igneous point sources. It is conceivable, however, that an igneous point source could exist in the basement of a basin, such as the San Bernardino and western Gila River valieys, but that is apparently not the norm. The only remaining choice is thermal gradient; if one cannot take the heat to the water, one must take the water to the heat. The Basin and Range disturbance, initiated during late Oligocene to eariy Miocene ( 20 m.y.B.P.) (Loring, 1976), with its associated deep faulting, basin formation and sedimentation offers a general solution to the heat source problem. Keller, Grose, and Crewdison (1978), using a geophysical approach, came to the same conciusion. Water is apparently circulated downward throush permeable faults in the mountain block and bounding and transverse fault zones in the bottom of the basin. Waters, heated by thermal gradient, rise by convection into the basin where some of it may be trapped in the lower part of the basin, Unit I (?) of Eberly and Stanley, by overlying, impermeable basin-fill material such as shales and silts. These same materials provide insulation from coler, descending waters. Direct evidence for the existence of these hot water reservoirs at cepth, such as high temperature gradients, low resistivities, hot springs and wells, usualiy is sparse. These deeper reservoir sites are easily masked by the movement of cool groundwater through the upper part of the basin fill, Unit II (?) of 
Eberly and stanley. Heat transfer, however, can occur via conduction through a reservoir cap rock, sometimes leading to convection in overlying water-saturated sediments. Heat transfer also occurs through leakage of warm or hot water upward along basin margin faults or fractures and through fractures in the basin-fill material. Figure 7 is a schematic drawing of a Basin and Range province geothermal system as it is presently envisioned for many basins in Arizona. However, exploration of the south Santa Cruz basin near Coolidge (Dellechaie, 1975) shows that this diagram does not hold true for all basins in the Basin and Range province of Arizona. The more obvious possibilities for compromise are impeded plumbing systems and/or the absence of an effective "cap" rock needed to retain the heat and trap the hot water. This model, which emphasizes the natural geologic setting, is believed to offer realistic opportunities to explore for and develop viable geothermal energy resources in the Basin and Range province of Arizona. It is in this province, where over 90 percent of the state's population resides, that energy demands are and will be increasingly concentrated.

\section{CONCLUSIONS}

Arizona has a realistic potential for the development of viable geothermal energy resources. These resources are buried, and their geological manifestations often are very subtle. 
C

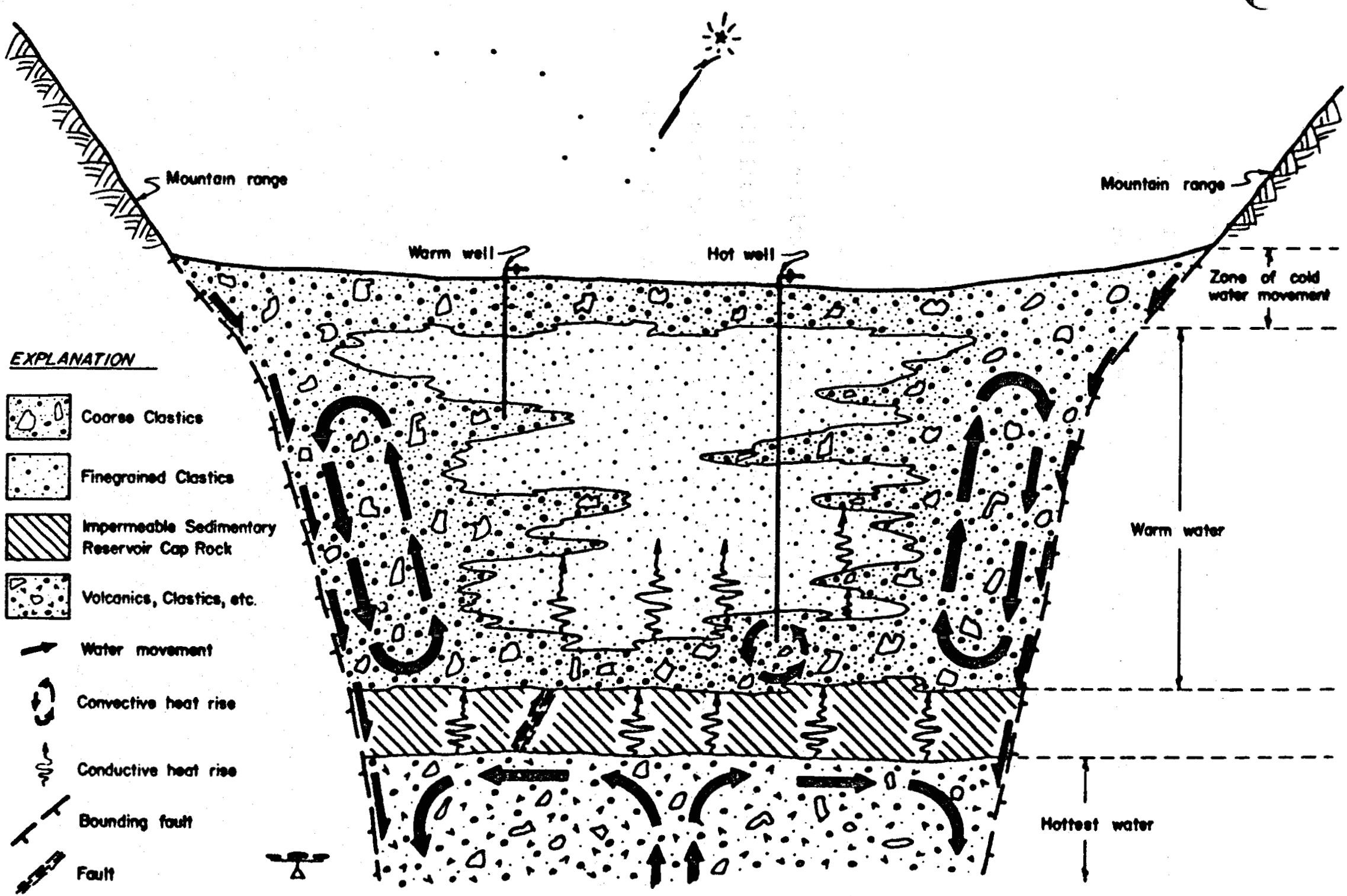

FIGURE 7. Schematic composite cross section showing proboble reservoir formation ond heof tronsfer mechonisms existing in basins of the Basin and Range province of Arizono. 
However, we are encouraged that they can be located and developed through prudent, integrated programs utilizing geology, geophysics, and geochemistry, the principal exploration tools.

\section{ACKNOWLEDGEMENTS}

The writer wishes to acknowledge the staff of the Geothermal project. This article could not have been written without their input of time and discussion. The writer also wishes to thank his reviewers, H. W. Peirce, A. W. Laughlin, A. K. Loring, C. Stone and J. P. Jenney for their constructive comments. Any errors of fact or interpretation are the sole responsibility of the writer. 


\section{BIBLIOGRAPHY}

Amstead, H.C.H., 1978, Geothermal Energy - Its Past, Present and Future Contributions to the Energy Needs of Man, John Wiley \& Sons, Inc., New York, 375 p.

Bierman, S.L., Stover, D.F., and Lamont, W.J., 1978, Geothermal Energy in the Western United States, Praeger Fublishers, New York, $466 \mathrm{p}$.

Byerly, D.E., and Stolt, R.H., 1977, An attempt to define the Curie point isotherm in northern and central Arizona: Geophysics, Vo1. 42 , No. 7 .

Chapman, D.S., Kilty, K.Y., and Mase, C.W., 1978, Temperatures and their dependence on groundwater flow in shallow geothermal systems, Geothermal Resources Council, TRANSACTIONS, Vol. 2, p. 79-82.

Dellechaie, Frank, 1975, A Hydochemical Study of the South Santa Cruz Basin near Coolidge, Arizona, Proceedings, Second United Nations Symposium on the Development and Use of Geothermal Resources, Vol. 1, p. 339-348.

Eberly, L.D. and Stanley, Jr., T.B., 1978, Cenozoic stratigraphy and geologic history of southwestern Arizona, G.S.A. Bulletin, Vol. 89, p. 921-940.

Fournier, R.O., and Rowe, J.J., 1966, Estimation of underground temperatures from the silica content of water from hot springs and wet-steam wells: American Journal of Science, Vol. 264, p. 685-697.

Gerlach, T., Norton, D., DeCook, K.J., and Sumner, J.S., 1975, Geothermal water resources in Arizona: Feasibility Study, University of Arizona, Tucson, $36 \mathrm{p}$.

Giardina, Jr., S., 1978, Geothermal anomalies, Basin and Range province of Arizona, Interstate Oil Compact Commission Committee Bulletin, Vol. 20, No. 20.

Hahman, Sr., W.R., 1977-1979, Geothermal reservoir site evaluation in Arizona, Quarterly and semiannual progress reports, May 1, 1977 - July $31,1977,7$ p. August 1, 1977 - October $31,1977,12$ p. November 1, 1977 - January $31,1978,23$ p. February 1, 1978 - April 30, 1978, $120 \mathrm{p}$. July 15, 1978 - January 15, 1979, $157 \mathrm{p}$. Bureau of Geology and Mineral Technology, Geological Survey Branch, Tucson. 
Hahman, Sr., W.R., Stone, C., and Witcher, J.C., 1978, Preliminary Map, Geothermal Energy Resources of Arizona, Geothermal Map No. 1, Bureau of Geology and Mineral Technology, Geological Survey Branch, Tucson.

Keller, G.V., Grose, L.T., and Crewdson, R.A., 1978, Speculations on nature of geothermal energy in Basin and Range province of western United States: Culorado school of Mines Quarterly, Vol. 73, No. 4, Part 2 .

Krugrer, P., and Otte, C., 1973, Geothermal Energy, Stanford University Press, Stanford, $360 \mathrm{p}$.

Lachenbruch, A.H., and Sass, J.H., 1977, Heat flow in the United States and the thermal regime of the crust, in the Earth's Crust, Geophysical Monograph 20, John G. Heacock, ed., American Geophysical Union, Washington, D.C., pp. 626-675.

Laughlin, A.W., 1979, Personal communication, Los Alamos Scientific Laboratory.

Loring, A.K., 1976, The age of Basin and Range faulting in Arizona, Arizona Geological Society Digest, Vol. 10, p. 229-257.

Mason, B., 1958, Principles of Geochemistry, 2nd Edition, John Wiley \& Sons, Inc., New York, 310 p.

Reiter, M., Mansure, A.J., and Shearer, C., 1978, Geothermal Characteristics of the Colorado Plateau in Plateau Uplift, Mode and Mechanism: Compiled by the Lunar and Planetary Institute, Contribution 329, Houston, p. 43.

Reiter, M. and Shearer, C., 1979, Terrestrial Heat Flow in Eastern Arizona, A First Report: Journal of Geophysical Research, in press.

Scarborough, R.B. and Peirce, H.W., 1978, Late Cenozoic Basins of Arizona, New Mexico Geol. Soc. Guidebook, Land of Cochise, pp. 253-259.

Stone, C., 1979, An overview of the geothermal potential of the Springervilie area, Arizona; in Hahman, Sr., W.R., Geothermal reservoir site evaluation in Arizona, Semiannual progress report, July 15, 1978 - January 15, 1979 , Bureau of Geology and Mineral Technology, Geological Survey Branch, p. 1-25. 
Swanberg, C.A., Morgan, P., Stoger, C.H., and Witcher, J.C., 1977, An Appraisal Study of the Geothermal Resources of Arizona and Adjacent Areas in New Mexico and Utah and Their Value for Desalination and Other Uses, Report No. 6, New Mexico Energy Institute, Las Cruces, $76 \mathrm{p}$.

Swanberg, C.A., 1979, Personal communication, New Mexico State University.

Wahl, E.F., 1977, Geothermal Energy Utilization, John Wiley \& Sons, New York, 302 p.

Witcher, J.C., 1979, A preliminary report on the geothermal energy potential of the Safford Basin, southeastern Arizona, in Hahman, Sr., W.R., Geothermal reservoir site evaluation in Arizona, Semiannual progress report, July 15, 1978 - January 15, 1979, Bureau of Geology and Mineral Technology, Geological Survey Branch, p. 42-72.

Witcher, J.C., 1979, A preliminary study of the geothermal potential of the Tucson metropolitan area, in Hahman, Sr., W.R., Geothermal reservoir site evaluation in Arizona, Semiannual progress report, July 15, 1978 January 15, 1979, Bureau of Geology and Mineral Technology, Geological Survey Branch, p. 73-91. 


\section{PREL IMINARY GEOTHERMAL \\ ASSESSMENT OF THE \\ WILLCOX BASIN}

by Nile 0 . Jones

with a section on hydrology by

Alice Campbell

BUREAU OF GEOLOGY AND MINERAL TECHNOLOGY

GEOLOGICAL SURVEY BRANCH GEOTHERMAL GROUP

$$
\text { July, } 1979
$$

PREPARED FOR THE

U.S. DEPARTMENT OF THE INTERIOR, BUREAU OF RECLAMATION, AND IN CONJUNCTION

WITH THE DEPARTMENT OF ENERGY, DIVISION OF GEOTHERMAL ENERGY, UNDER CONTRACT EG-77-S-02-4362 


\section{INTRODUCTORY MATERIAL}

\section{A. Location and Access}

The Willcox Basin is part of the Sulfur Springs Valley, a north to northwest-trending basin feature which spans Cochise and Graham Counties of southeastern Arizona. The hydrologic basin of this study is in the central region of the valley (Figure I-1).

Agricultural communities of Willcox, Bonita, Dos Cabezas, Kansas Settlement and Cochise are contained within the area. Major highways to Tucson, Bisbee and New Mexico pass near Willcox. Numerous improved dirt roads and farm roads crisscross the flatlands.

B. Local Support

Successful conclusion of this project is due to the high degree of local support and cooperation received from the inhabitants of the area. Numerous ranchers and farmers allowed us access to their wells and springs. Civic leaders in the community of Willcox realized the importance of developing additional water resources within the basin. They provided free access to their records as well as introductions to the owners of many of the anomalous wells. Special recognition should go to the employees of Apache Station Fower Plant (Arizona Electric Power Co-Operative, Inc.) in Cochise, who allowed us to log several of their unused wells, and to the staff of the University of Arizona Cooperative Extension Service for the fine records they have kept over the years. 


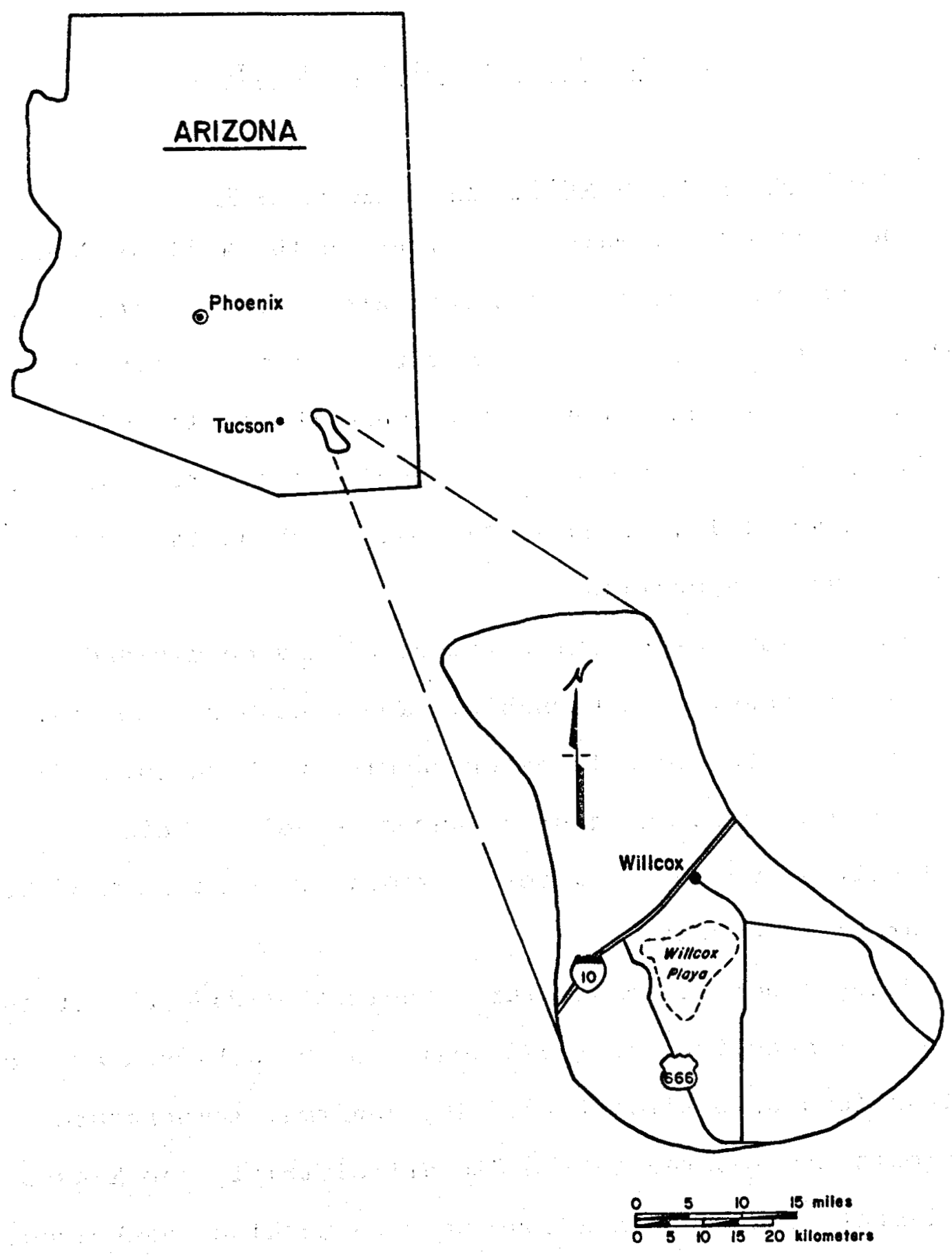

FIGURE I-1. Location of the Willcox Basin, Arizona. 


\section{SUMMARY AND RECOMMENDATIONS}

\section{A. Development of Potential Water Resources}

An inventory of water resources in the Willcox Basin and the surrounding recharge area indicate there is little opportunity for developing surface water. Annual precipitation records for the last eighty years show the center of the basin receiving about 12 inches $(53 \mathrm{~cm}$ ) while the surrounding mountains get about 18.6 inches $(47 \mathrm{~cm})$. Much of this water is lost through evaporation.

The subsurface resource potential may be divided into two catcgories; usable and unusable. The unusable water may be the result of unfavorable water chemistry, high total dissolved solids (TDS), or it may just be unrecoverable. This is at least $0.53 \times 10^{6} \mathrm{hm}^{3}$ of water in storage. A minimum of $26 \times 10^{3}$ $\mathrm{hm}^{3}$ can be recovered.

Using a normal temperature gradient of $34^{\circ} \mathrm{C} / \mathrm{km}$ for the basin, a temperature of $150^{\circ} \mathrm{C}$ would not be achieved at a depth of less than 3.75 kilometers. The abnormal temperature gradients are located in the Stewart district, the Kansas Settlement area, and in a zone between Cochise and Pearce. Should these gradients continue with depth, the minimum powerproducing temperature of $150^{\circ} \mathrm{C}$ would be attalned at 3 kilometers or less. 


\section{LAND STATUS}

The Willcox Basin has a maximum length of $80 \mathrm{~km}$ and a maximum width of $26 \mathrm{~km}$. The basin proper covers an area slightly in excess of $2,000 \mathrm{~km}^{2}$, while the total watershed area is about $4,100 \mathrm{~km}^{2}$ (Map III-1). Table III-l gives a breakdown of the land situation by major land holders.

Table III-1. Land Status of Willcox Basin, Arizona

Owner or Trust Group

Private ownership

State of Arizona trust

National Forest

National Reservation (Military)

BLM Resource Lands

TOTAL
Area $\left(\mathrm{mi}^{2}\right)$

1104.7

249.4

156.5

60.2

23.5

1594.4
Area $\left(\mathrm{km}^{2}\right)$

2861.2

645.8

405.3

156.0

60.9

$\overline{4129.2}$

Approximately $11 \%$ of the land belongs to the National Forest Service and the Bureau of Land Management. Over $15 \%$ of the land is held in trust by the state of Arizona, $69 \%$ is privately owned, and the remainder belongs to the military. 
IV. RESOURCE EVALUATION

\section{A. Introduction}

A review of existing data concerning the Willcox Basin was undertaken as a first step in assessing the area's geothermal potential. This, coupled with additional information gathered from firsthand field examinations and explicit water chemistry suggest three areas where temperatures from 40 to $100^{\circ} \mathrm{C}$ may be found at depths of 500 to 1,000 meters. Projection of thermal gradients within the basin suggest energy-producing temperatures at depths of about 3,000 meters. Further delineation of these more favorable zones will require additional site-specific work.

B. Previous Work

The geology of the area has been described by various authors interested in specific probelms. Kellogg (1906) followed by Meinzer and Kelton (1913) provided early surveys of the geology and ground-water resources; and Cooper (1959, 1960) published reconnaissance geologic maps of the region. Ground-water was studied by Heindl and DeCook (1952), Brown and Schumann, (1969), and others, while the Willcox playa was examined by Pine (1963), Robinson (1965), Long (1966), and Schreiber et al. (1972, 1978). Willcox Basin has been included as part of regional gravity and aeromagnetic studies (Sauck and Sumner, 1970; Aiken and Sumner, 1974; Aiken, 1975; Texas Instruments, Inc., 1978). 


\section{Geology}

The Willcox study area can be divided into two major structural units: 1) bedrock mountain blocks, and 2) a basin block containing poor to moderately-induratec basin fill sediments. Much of the following discussion will pertain to the basin fill sediments and the underlying bedrock structures. It is important, however, to recognize the diversity of rock types, structures and ages of the exposed mountain blocks since they are the major source of the clastic material.

1. Surrounding Mountain Blocks. Almost all major rock types are represented in the mountains bordering the Willcox Basin, and their lithologies' ages range from Precambrian to Cenozoic. These rock types include: Precambrian granite, gneiss and schist; Paleozoic limestone, sandstone and shale; Cretaceous sediments; and Quaternary alluvium with minor basalt flow tuffs, breccias and cinder cones (Map IV-I). The mountains in this region are considered to be horst-block segments. The intervening graben block has subsequently been covered by basin-fill sedimerts. Mid-Tertiary volcanism occurred throughout southern Arizona during the period 32-20 m.y. The Chiricahua Mountain volcanics $(28-24 \mathrm{~m} . \mathrm{y}$.$) (Marjaniemi, 1969) and the$ Galiuro-Winchester mountains volcanics (29-22 m.y.) (Creasey and Krieger, 1978) fall well within this period. The emplacement of these volcanic units predates the late Miocene 
$i \neq-5 \mathrm{~m} . \mathrm{y}$.$) "Basin ard Range disturionce" as cefined by$ Scarborough and Peirce (1978).

2. Wiilcox Basin Sediments. The Hillcox Basin sediments have been subdivided into two units, upper and lowr. The lowr unit contains nolerately indurated complomerates, sandstones and mudistones (Table iv-i). Ihis lower unit exhibits local deformation by faulting and/or tilting. Outcrops northeast of the circie I hills are tilted by as much as $29^{\circ}$ (Brown and Schumann, 1969). Based on the degree of consolidation, deformation and composition, the conglomerates, sand silt and gravel are of Tertiary age; the pooriy consolidated sand, silt, clay and fravol are Tortiary-Quaternary (Brown and Schumann, l9(i9); Schroibur, 1978). Division of the Willcox Basin sudimonts into upper and lower units is consistent with the boundary divisions proposed by Eberly and Stanley, Jr. (1978) for the Cenozoic basins of southwestern Arizona. librloy and Stanloy, Jr. (1978) mark the boundary between their older lnit I and younger unit II by locating a widespread unconformity surface associated with a new cycle of subsidence, block-faulting and erosion that began in late Miocene $(13-12 \mathrm{~m} . \mathrm{y}$.$) .$

The upper unit at Willcox is set apart from the lower by its lack of consolidation, increase in percentage of finer-grained material and the occurrence of evaporite minerals. The present valley floor is covered by a thin veneer of unconsolidated Quaternary sand, silt and clay. 
GENERALIZED STRATIGRAPHIC COLUNN CF THE SEDIMENTS IN THE WILLCOX BASIN, ARIZONA.

\begin{tabular}{|c|c|c|c|c|}
\hline \multicolumn{3}{|l|}{ COLUMN } & GEOLOGIC UNIT & CHARACTERISTICS \\
\hline \multirow{6}{*}{$\int_{\frac{5}{30}}^{\frac{5}{3}}$} & \multirow{2}{*}{\multicolumn{2}{|c|}{ 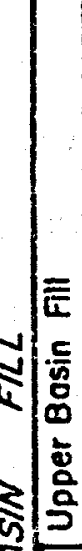 }} & $\begin{array}{l}\text { LAKE BED } \\
\text { DEPOSITS }\end{array}$ & $\begin{array}{l}\text { Yellow, gray, and biack cioy } \\
\text { and silt, with sypsum and sond } \\
\text { locolly interbedoded. Morgins are } \\
\text { locally overlain by thin beach } \\
\text { grovel and sand dunss: pcrtiolly } \\
\text { dissected. }\end{array}$ \\
\hline & & & STREAM DEPOSITS & $\begin{array}{l}\text { Alluvial deposits of pink io } \\
\text { red-brown sand, grayel, sith, } \\
\text { and clay; inferbedied to } \\
\text { lenticular. Conglomeroie may } \\
\text { mark unconformity. }\end{array}$ \\
\hline & 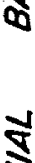 & $\equiv$ & Poorly Consolidated & $\begin{array}{l}\text { Lenticular zones of pink to } \\
\text { grayish-brown sand, grovel, } \\
\text { silt, and clay; poorly incuroted. }\end{array}$ \\
\hline & & 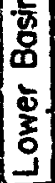 & $\begin{array}{l}\text { Moderotely } \\
\text { Consolidated }\end{array}$ & $\begin{array}{l}\text { Conglomerates, sand, gravel, } \\
\text { silt; interbedded, moderatoly } \\
\text { indurated. Volcanic frogmants } \\
\text { may be found in sandy matrix. }\end{array}$ \\
\hline & 3 & & BEDROCK & $\begin{array}{l}\text { Igneous, metomorphic, and } \\
\text { sedimentary units simila: to } \\
\text { those thot are exposed in the } \\
\text { adjocent hills and mountoins. }\end{array}$ \\
\hline & & & & \\
\hline
\end{tabular}

TABLE IY-1 
The margins of the basin have a gravel cover while the playa contains lake muds, clays and evaporites. The shifting position of the playa can be seen from the remnant beach gravels to the north and west of the playa and in the cuttings from nearby wells.

A number of wells have been drilled for water while a few were drilled for petroleum exploration. Available lithologic logs and well cuttings show the basin to be in excess of 2,000 meters deep. Geophysical evidence indicates portions of the basin may be as deep as 4,000 meters (Aiken, 1978). A generalized stratigraphic column constructed from the logs and cuttings is given in Table IV-1. Sections across the basin are shown in Figures IV-1-2-3- and 4.

$\Lambda$ high percentage of clay or "stickey shale" (drillers logs) is present throughout the central portions of the basin. These fine-grained clastics indicate periods of low energy deposition. Such periods may be either a local or a widespread phenomenon, depending on topographic relief and precipitation. These clay units, along with the even more localized caliche horizons, impede the downward movement of percolating water. Vertical permeability reductions, over so broad an area as the Willcox Basin, impede the natural ground-water recharge. The impervious nature of the nearsurface lay layers is demonstrated every rainy season when the playa becomes a large, shallow lake. The intermittent lake lasts for a number of weeks following the rainy season. 


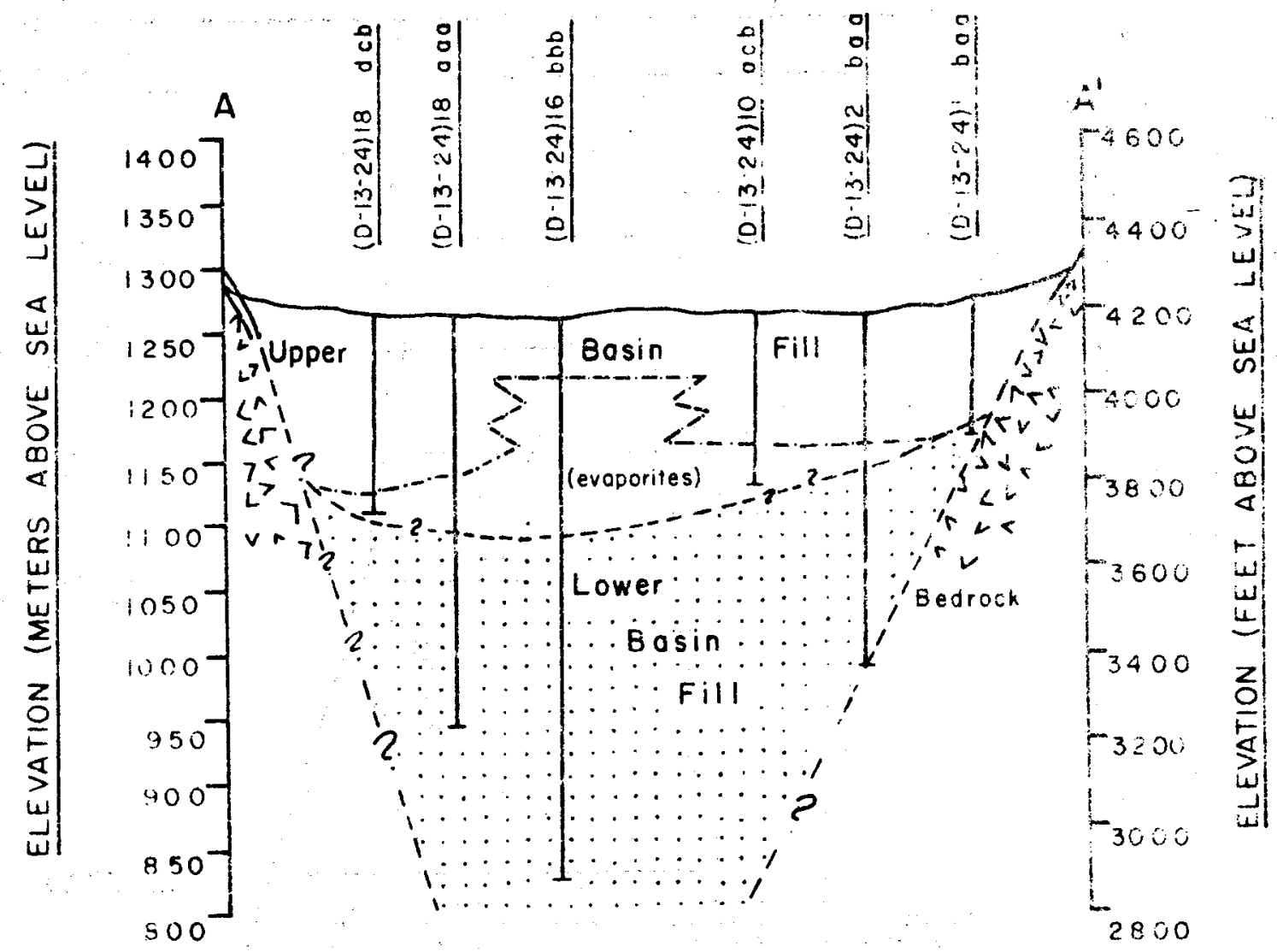

Miles

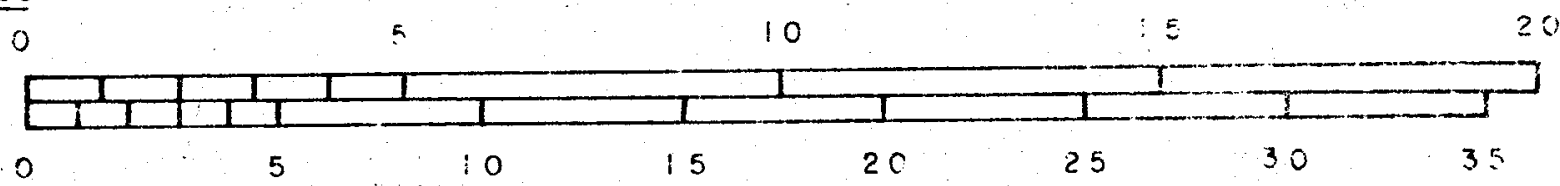

Kilometers

FIGURE IV-i, CROSS SECTION A-A', WILLCOX, ARIZONA. 

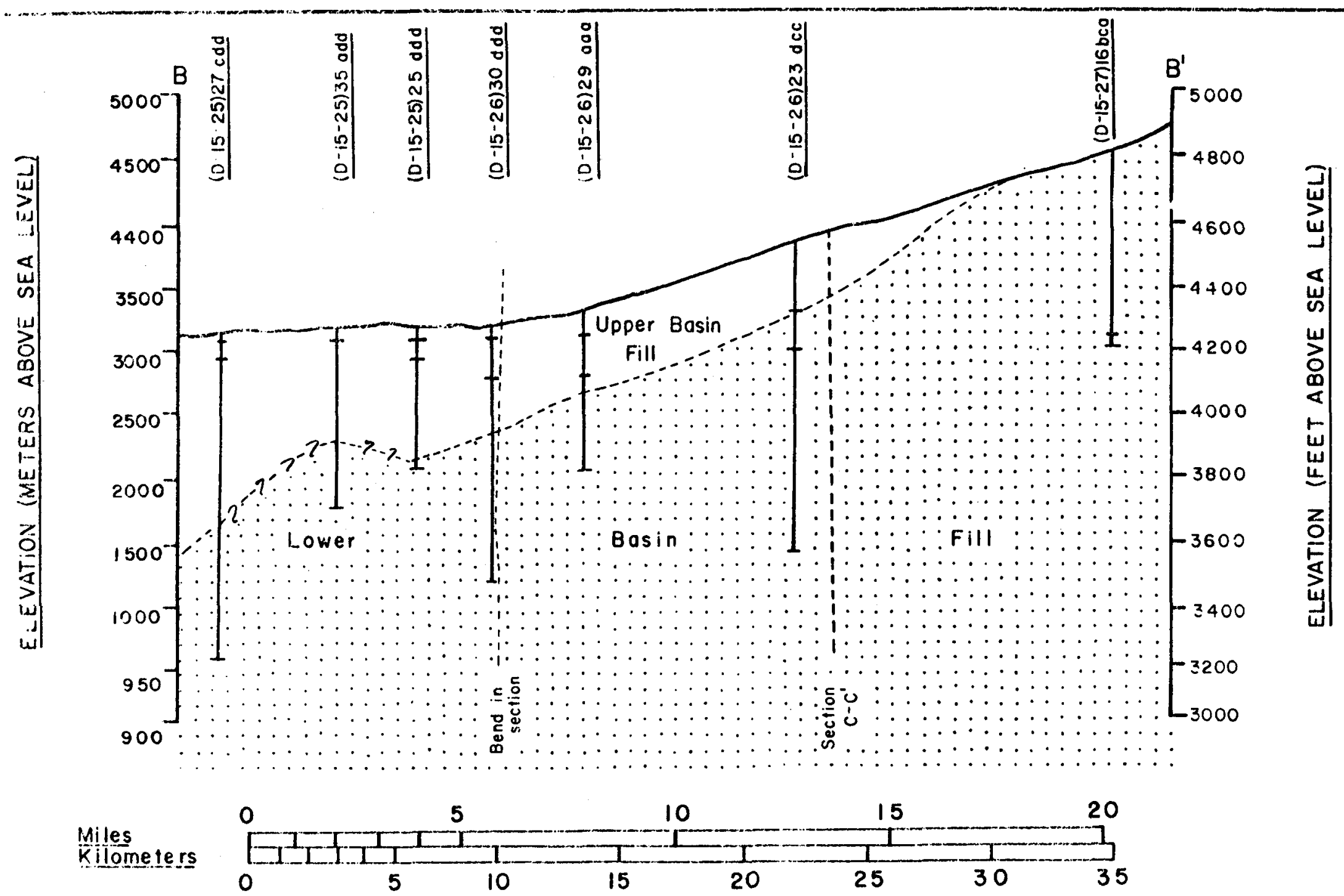

FIGURE IV-2. CROSS SECTION B-B', WILLCOX, ARIZONA. 


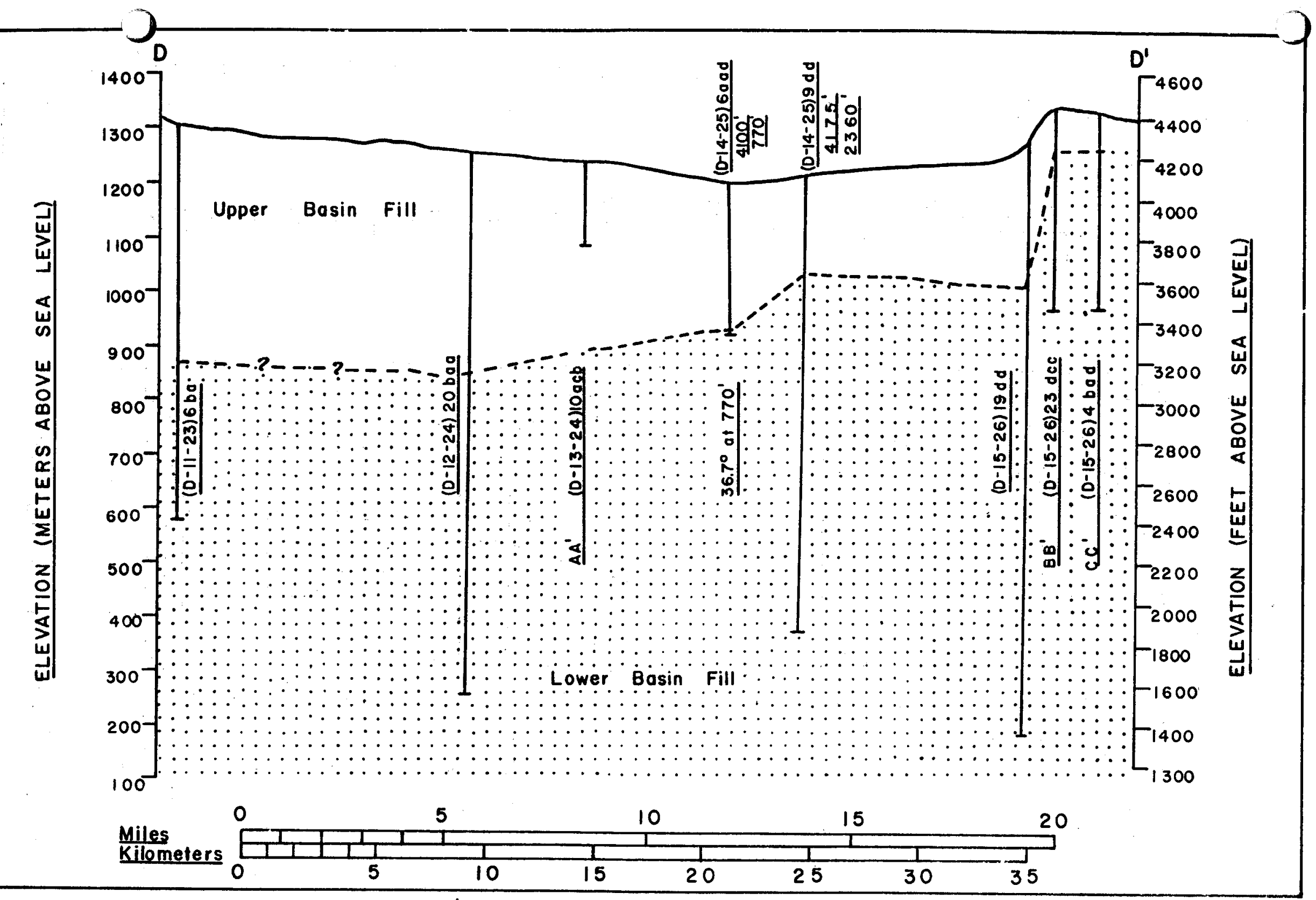

FIGURE IV-4. CROSS SECTION D-D', WILLCOX, ARIZONA. 
The playa surface is again exposed only after the water has been removed through evaporation or ground-water recharge. The stream deposits that are adjacent to, or underlie the lake-bed deposits are composed of interbedded sand, gravel, silt and clay. These units provide the main avenues for ground-water recharge. These strata are also the most heavily developed by the farmers because of their high water yield at depths generally less than 100 meters.

Other wells in the area include those along the margins of the basin and those collared in bedrock. Wells located near the margins of the basin generally yield small quantities of water due to elther the thinness of the alluvium or the low permeability of the bedrock. The bedrock wells must rely on fractures or faults for the main water conduits. This generally restricts well yields.

3. Water Chemistry, Maps IV-2 and IV-3 show the distribution of fluoride and total dissolved solids, respectively. Numerous wells in and around Willcox produce waters which have $2 \mathrm{mg} / 1$ or more fluoride. Recommended limits of fluoride in drinking water in the Willoco area is less than half this value (Hem, 1970). Similar concentrations are found in wells located along the margins of the Willcox playa and in the Kansas Settlement area. The majority of wells sampled throughout the basin contain less than $500 \mathrm{mg} / 1$ dissolved solids. In general, the quantity of dissolved solids in the ground water decreases away from the playa. 
The water quality of selected wells and areas within the basin was evaluated by Meinzer and Kelton (1913), Kister and others (1966) and for this Arizona Bureau of Geology staff report. Heavy pumping for irrigation purposes has caused a real decrease in the amount of dissolved solids (salinity) found in the shallow aquifers. This is most noticeable in the Stewart area, north of Willcox. Early reports on this area show the quality of water in terms of salinity to be much poorer than is observed today. Kister and others (1966) attributed this upgrading to a "skimming" of high saline waters from off the top of the water table. The resultant decline in the water table has left the remaining saline "scum" above the present water level. Wells drilled in the Kansas Settlement area have also undergone this favorable shift in salinity over a period of the last 20 years.

Wells drilled below the upper aquifers also exhibit variations in their chemical character. Table IV-2 is a listing of typical analyses for some of the wells greater than 300 meters. The water samples which are high in soluble salt probably came in contact with evaporite-type minerals. Magnesium is low throughout, expecially when it is compared to the concentration of soluble salt. Fluoride does not follow a conspicuous pattern in relation to the other elements listed in the table.

There are three possible sources for the fluoride: 
Table IV-2. Water Chemistry of Selected Deep Wells in the Willcox Basin, Arizona

\begin{tabular}{|c|c|c|c|c|c|c|c|c|c|c|}
\hline Location & $\begin{array}{l}\text { Depth of } \\
\text { Well (m) } \\
\end{array}$ & $\begin{array}{l}\text { Soluble Sal ts } \\
\text { (mg/1) }\end{array}$ & $\begin{array}{c}\mathrm{Ca} \\
(\mathrm{mg} / 1) \\
\end{array}$ & $\begin{array}{c}\mathrm{Mg} \\
(\mathrm{mg} / 1) \\
\end{array}$ & $\begin{array}{c}\mathrm{Na} \\
(\mathrm{mg} / 1) \\
\end{array}$ & $\begin{array}{c}\mathrm{cl} \\
(\mathrm{mg} / 1) \\
\end{array}$ & $\begin{array}{r}\mathrm{s \sigma}_{4} \\
(\mathrm{mg} / \mathrm{I}) \\
\end{array}$ & $\begin{array}{r}\mathrm{CO}_{3} \\
(\mathrm{mg} / \mathrm{I}) \\
\end{array}$ & $\begin{array}{l}\mathrm{HCO}_{3} \\
(\Xi \mathrm{g} / 1)\end{array}$ & $\begin{array}{c}F \\
\text { (mg/1) } \\
\end{array}$ \\
\hline$D(13-24) 11 a b$ & 411 & 295 & 0 & 0 & 106 & 24 & 60 & 0 & 98 & 10.0 \\
\hline$D(13-24) 23 d c$ & 2,095 & 214 & 10 & 2 & 48 & 14 & 11 & 0 & 129 & 2.6 \\
\hline$D(13-25) 5$ & 762 & 1,380 & 7 & 3 & $502 *$ & 360 & 262 & 0 & 302 & 12.0 \\
\hline$D(13-25) 31 \mathrm{cab}$ & 549 & 1,272 & 3 & 0 & 428 & 344 & 200 & 0 & 298 & 2.6 \\
\hline$D(14-25) 4 C$ & 427 & 1,495 & 30 & 4 & 427 & 372 & 285 & 0 & 371 & 6.0 \\
\hline$D(14-25) 7 d$ & 671 & 15,900 & 17 & 13 & 5,660 & 3,200 & 6,450 & 54 & 520 & - \\
\hline$D(15-25) 28 d d d$ & 396 & 585 & 54 & 6 & 117 & 72 & 160 & 0 & 176 & 1.2 \\
\hline$D(17-26) 10$ add & 695 & 269 & 14 & 3 & 63 & 12 & 42 & 0 & 127 & 8.0 \\
\hline
\end{tabular}

*Na \& $\mathrm{K}$ 
i) solution of fiuorire-bearing minerals which occur in the beơrock volcariics, granites aná schists, 2) solution of fluorine-bearing minerais which occur in the basin sediments that were derived from the volcanics granites ana schists, and 3) waters and gases associated with volcanic activity or other deep-seated heat sources. Fiuoride concentrations in excess of $10 \mathrm{mg} / 1$ for ground waters are unusual. Indeed, most natural waters sampled around the world contain less than $2 \mathrm{mg} / \mathrm{l}$ fluoride when the dissolved solids concentration is less than $1,000 \mathrm{mg} / \mathrm{i}$ (Hem, 1970).

Evapotranspiration from an area of internal drainage wouid cause a buildup of saits, a phenomenon that would be reflected in the water chemistry. Through such a mechanism there would be an increase in the salinity of ali nearsurface waters. Noreover, most of this buildup in cations and anions would occur along the upper portions of the water tabie. Removai of these upper levels of ground-water would effectively reduce the salinity of subsequently-pumped horizons, as was discussed previously. Weils that draw exclusiveiy from deeper aquifers would be free of this surface-leach phenomenon. The water chemistry of these deeper weils shouid not show such marked changes through time. Waters tinat move through evaporite-type sediments will pick up anions and cations that refiect the nature of the evaporite mineralogy. Gypsum and anhyarite are the two ieast soiuble evaporite minerais in the Wiicox Basin. 
Should ground water move through one of the gypsum-rich zones it would become saturated, through time. Such water would contain low total dissolved-solids.

Reflecting again on the analyses in Table IV-2, the low dissolved-solids waters are heavily influenced by the presence of gypsum with minor amounts of halite. The waters containing higher amounts of soluble salts $(<1,000$ $\mathrm{mg} / 1$ ) do so because of higher amounts of halite.

4. Geophysics. State-wide aeromagnetic and gravity maps for Arizona have been compiled by the College of Geosciences, University of Arizona (Sauck and Sumner, 1970; Afken, 1975). Portions of the study area have also been mapped by Texas Instruments, Inc. (1978) as part of the National Uranium Resource Evaluation (NURE) program. Map IV-4 shows the residual aeromagnetic data on the topographic base map of the area. Map IV-5 is a residual gravity map with inferred deep structures at a similar scale. Magnetic and gravity surveys are similar in that both methods measure small differences in a large force fleld. Gravity surveys deal with variations in rock density while magnetic surveys measure changes in the terrestrial magnetic field.

Contour intervals are $5 \mathrm{mgal}$ on the residual gravity map. No terrain corrections have been applied to the contoured data as they are less than $0.2 \mathrm{mgal}$ for most sites within the area of interest. Such small changes would not 
significantly alter the overall pattern (Decker and others, 1975). Maximum difference in contour values is about 45 mgal and represents the density contrast between sediments and volcanics in the deeper portions of the Cenozoic basin and the bedrock in the surrounding mountain ranges. Modeling exercises were conducted on alternating Bouguer highs and lows which took into account the contrasting rock types and rock densities (Aiken, 1978; Aiken and Sumner, 1974). The model that best fits the data was predicated on the assumption that the deeper portions of the basin were underlain by rocks similar in composition to those exposed in the mountain blocks. The result is a series of northwest-trending graben blocks located more or less along the trace of the Sulfur Springs Valley. Sediments have been deposited on top of the graben blocks in direct proportion to the depths of the graben segments and at a rate commensurate with the displacement and duration of the block faulting. The deepest portion of the basin is located northwest of Willcox, near the steward area. Another area just east of Courtland is also quite deep. Estimates for the maximum thickness of sediments in these two areas are 4 and 3 kilometers respectively.

A horst and graben model developed from the gravity data and checked against the deep oil test holes within the basin suggests fault movement along fairly well-defined lineaments. The irregular nature of the gravity anomalies 
under the present topographic basin outlines possible axial and planar rotation accompanying the differential vertical movement. Steep gradients along the boundaries of the prominent gravity lows delineate the trace of the major normal faults. Oblique iso-gravity IInes such as those just south of Willcox most likely represent cross-bounding faults. If this is the case, then the apparent offset as seen in the trace of these oblique lines represents a rifting of the area during the Basin and Range orogeny. The gravity low due north of the Swisshelm Mountains extends eastward into the Chiricahua Mountains. This low encompasses the majority of the Turkey Creek caldera as defined by Marganiemi (1969). It is consistent with the rifting and horst-graben models if the faulting and vertical displacements occur after the development of the caldera. Marganiemi's radiometric dates from the volcanic pile range from $16.2 \pm 1.6 \mathrm{~m} . \mathrm{y}$. to $28.9 \pm 1.9 \mathrm{~m} . \mathrm{y}$. The location of volcanic debris and ash in adjacent mountain ranges demonstrates the region-wide influence of this event. All volcanic units associated with, and in close proximity to. the proposed caldera have been faulted and tilted. A major horst block, 5-6 km wide, is located south of the caldera. Although this horst could be part of the ring fracture system, it nevertheless has its orientation subparallel to the Sulfur Spring Valley.

Aeromagnetic data is in agreement with what has already 
been observed or inferred by the surface geology. Inflections in the magnetic patterns under the basin generally coincide with the inferred faulting. Steep gradients can be related to basin faulting, as was the case with the gravity data.

5. Water Temperatures and Gradients. The majority of wells completed in the Willcox Basin are used for irrigation and do not exceed $100 \mathrm{~m}$. in depth. A literature search supplemented by local observation of a limited nature indicates at least 21 sites where natural waters have temperatures greater than $30^{\circ} \mathrm{C}$. The maximum recorded temperature is $86.7^{\circ} \mathrm{C}$ from an oil test well which is in excess of $2,000 \mathrm{~m}$. deep. All hot wells and springs currently known are listed in Table IV-3. None of the hot springs are discharging at this time.

Temperature gradients were calculated by subtracting the mean annual air temperature from the observed water temperature, then dividing by the depth of the well. All calculations utilized the Celsius and metric scales. The temperature gradients were assigned to one of four categories, then plotted on Map IV-6.

Most well temperatures are taken at the wellhead; thus, they measure either the discharge temperature of the water or the temperature of the drill mud. In most instances, these recorded values do not indicate the depth of the producing zone, nor do they take into account the mixing 
Table IV-3. Wells and springs in the Willcox Basin with Temperatures of $30^{\circ} \mathrm{C}$ or Greater

\begin{tabular}{|c|c|c|c|c|c|}
\hline Locatic & & $\begin{array}{c}\text { Temperature } \\
{ }^{\circ} \mathrm{C} \\
\end{array}$ & $\begin{array}{l}\text { Depth } \\
\text { Meters }\end{array}$ & $\begin{array}{c}\text { Map } \\
\text { Quadrangle }\end{array}$ & Reference \\
\hline$(D-12-23)$ & $31 \mathrm{cb}$ & 54.4 & 136 & Winchester Mts. & 1 \\
\hline$(D-12-24)$ & $20 \mathrm{ba}$ & 37.9 & 460 & WIIlcox & 7 \\
\hline$(D-13-22)$ & $33 \mathrm{da}$ & 61.1 & 1612 & Winchester Mts. & 2 \\
\hline$(D-13-24)$ & $2 \mathrm{ba}$ & 31.7 & & Willcox & 3 \\
\hline$(D-13-24)$ & $5 \mathrm{ba}$ & 47.8 & 204 & Willcox & 1 \\
\hline$(D-13-24)$ & $11 \mathrm{ab}$ & 40.6 & 412 & Willcox & 1 \\
\hline$(1)-13-24)$ & $23 \mathrm{dc}$ & 86.7 & 2028 & Willcox & 2 \\
\hline$(D-13-25)$ & 5 & 31.1 & 762 & Wiilcox & 4 \\
\hline$(1)-13-25)$ & 31.ca & 31.7 & 229 & Wi11cox & 3 \\
\hline$(1)-13-25)$ & $31 c a$ & 32.8 & 577 & W111 cox & 2 \\
\hline$(1)-14-24)$ & $20 \mathrm{~cd}$ & 39.0 & Spring & Cochise & $\ddot{3}$ \\
\hline$(D-14-25)$ & $4 \mathrm{ba}$ & 31.1 & & Cochise & 3 \\
\hline$(D-14-25)$ & $6 a a$ & 36.7 & 235 & Cochise & 5 \\
\hline$(D-14-25)$ & $6 \mathrm{cb}$ & 35.0 & 214 & Cochise & 3 \\
\hline$(D-14-24)$ & $6 \mathrm{db}$ & 35.0 & 214 & Cochise & 3 \\
\hline$(D-14-25)$ & $10 a \mathbf{a}$ & 30.0 & & Cochise & 3 \\
\hline$(D-15-24)$ & $19 \mathrm{ba}$ & 30.0 & & Cochise & 3 \\
\hline$(D-15-26)$ & 19 & 43.3 & 980 & Cochise & 6 \\
\hline$(D-16-24)$ & $10 \mathrm{ac}$ & 40.4 & $* 415$ & Cochise & 7 \\
\hline$(D-16 \cdots 24)$ & $10 \mathrm{bd}$ & 35.6 & *350 & Cochise & 7 \\
\hline$(D-18-24)$ & $28 \mathrm{~cd}$ & 32.2 & Spring & Dos Cabezas & 4 \\
\hline
\end{tabular}


Table rV-3. (Contiated) Wolls and springs in the Wiilcox Basin with "emperalures of $30 \%$ c: or circitior

\section{Reference}

1 - Dutt, G.R., and McCreary, T.W., 1970.

2 - Giardina, S., Jr., and Coniey, J.N., 1978.

3 - U.S.G.S., WATSTORE File, 1979.

4 - Brown, S.G., and others, 1963.

5 - Peirce, H.W., and Scurlcck, J.R., 1972.

6 - Arizona Well Records Co., 1961.

7 - This report. 
of waters with different thermal quajity. Shallow welis with warm temperatures tend to produce high gradients. Warm temperatures may result from surface recharge of the shallowest waters or exothermic chemical reactions associated with oxidation or hydration. If a one degree temperature difference is recorded at 10 meters and at 100 meters, the simple temperature gradient for the former would be $100^{\circ} \mathrm{C} / \mathrm{km}$ and $10^{\circ} \mathrm{C} / \mathrm{km}$ for the latter. Therefore, no well less than 100 meters deep has been considered in the evaluation process.

There are 44 wells within the Willcox Basin whose depths exceed 100 meters and have recorded temperatures. Table IV-4 lists the arithmetic mean and weighted mean temperature gradeints for wells in the intervals 100-200 meters, 200-400 meters, and in excess of 400 meters. In contrast, the mean temperature gradient for all wells in excess of 300 meters in Cochise County is $28^{\circ} \mathrm{C} / \mathrm{km}$ (Giardina and Conley, 1978). Willcox Basin wells whose depths exceed 400 meters have temperature gradients 1.2 to 1.3 times the county-wide average. Figure IV 5 is a plot of simple temperature gradients versus the depth of well from which it came. The overlain bar graphs clearly demonstrate the thermal characteristics of the fillcox area with respect to the rest of the county. The deeper wells approach the maximum gradient profile and, therefore, imply geothermal potential. As pointed out before, 
Table IV-4. Temperature Cradients for Wolls in the Wlllowx Bas in Whose Depths Exceed 100 Meters

\begin{tabular}{|c|c|c|c|c|}
\hline $\begin{array}{l}\text { Interval } \\
\text { (Meters) } \\
\end{array}$ & $\begin{array}{c}\text { Number of } \\
\text { Wells } \\
\end{array}$ & $\begin{array}{c}\text { Average Depth } \\
\text { (Meters) } \\
\end{array}$ & $\begin{array}{l}\text { Arithmetic Mean* } \\
\text { Gradient }\left({ }^{\circ} \mathrm{C} / \mathrm{km}\right)\end{array}$ & $\begin{array}{l}\text { Weighted Mean** } \\
\text { Gradient }\left({ }^{\circ} \mathrm{C} / \mathrm{km}\right)\end{array}$ \\
\hline $100-200$ & 23 & 142.9 & 74.1 & 73.0 \\
\hline $200-400$ & 12 & 254.8 & 60.5 & 57.5 \\
\hline$>400$ & 9 & 850.0 & 36.8 & 33.6 \\
\hline \multicolumn{5}{|c|}{ * $\frac{\Sigma \text { (Temperature Gradient) }}{\text { Number of Wells }}$} \\
\hline
\end{tabular}




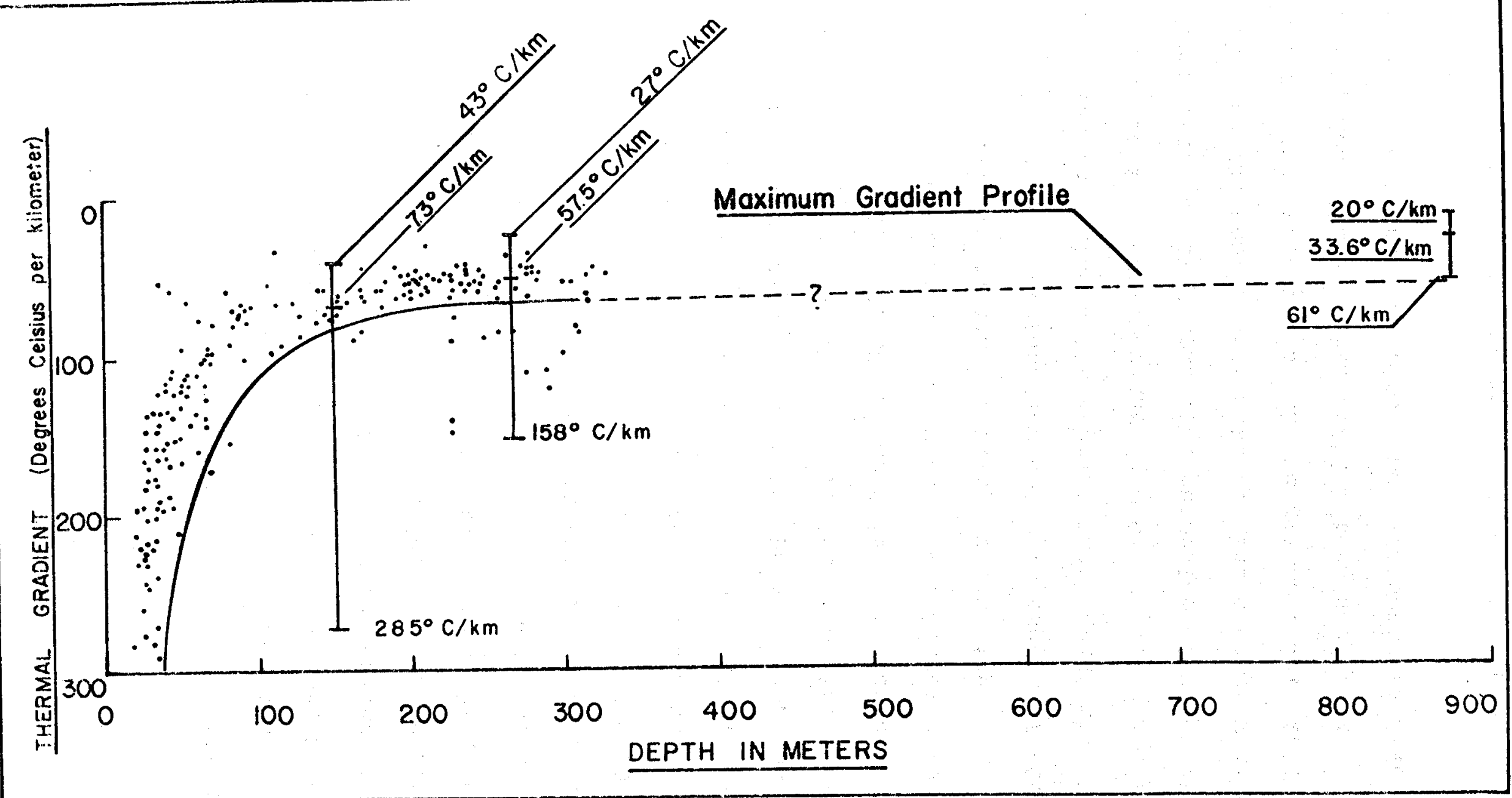
WILLCOX BASIN (AFTER GIARDINA AND CONLEY, 1978). 
excessively high temperature gradients at shailow depths (up to $50 \mathrm{~m}$ ) may be cuie to circuiation in the uppermost aquifers, recharge waters, or some form of exothermic chemical reaction. These causes for temperature gradient variance become less severe with depth as exemplified by the reduction range between the maximur and minimum temperature gracients within the two deeper sample sets.

Figure IV-5 reveals two additional points of interest: 1) there are a number of data points in the 200-300 meter range whose calculated temperature gradients well exceed the maximum gradient profile and 2) several of the deeper welis show temperature gradients approximating what would be expected from the maximum gradient profile. The high gradients in the 200-300 meter range are probably the result of communication between a heat source or sources and a rather thick zone of high permeability.

The gradient values for wells in excess of 400 meters are used to evaluate the average basin gradient. Since the welis in question range from 411 to 2,028 meters in depth, the weighted mean gradient valie of $33.60^{\circ} \mathrm{C} / \mathrm{km}$ is taken as the best approximation. The deepest well with known temperature is an oil and gas test well in T.13S, R.24W, Sec. 23dc. It is 2.028 meters deep, has a bottom hole temperature of $86.7^{\circ} \mathrm{C}$, and a temperature gradient of $350 \mathrm{C} / \mathrm{km}$.

Silica geothermometry from a small number of wells 
whose depths exceed 100 meters and observed temperatures are greater than $30^{\circ} \mathrm{C}$ give temperatures which are in general agreement with their observed wellhead temperatures. The kinetics of silic solubility are such that no deep reservoir temperature can be inferred from these particular data. Thus, the observed wellhead temperatures for those wells whose depths are between 200 and 300 meters will no doubt be close to the shallow reservoir temperature. Most likely temperatures to be encountered at these depths will be between $40^{\circ} \mathrm{C}$ and $50^{\circ} \mathrm{C}$.

The Na-K-Ca chemical geothermometer of Fournier and Truesdall (1973) was applied to those samples collected for this report or to wells with published information that was in a format that was commensurate with this type of analysis. Shallow wells (less than 200 meters deep) produced $\mathrm{Na}-\mathrm{K}-\mathrm{Ca}$ calculated temperatures approximating those observed at the welihead. In most cases, both the observed temperature and the calculated temperature was less than $30^{\circ} \mathrm{C}$. One must, therefore, conclude that these shallow aquifers are recharged from meteoric waters, and there is no obvious through-going communication between the heat source or sources and the shallow aquifers. Since the vast majority of wells do not exceed 200 meters, the preponderance of chemical information deals with these near-surface aquifers. 
Chemical information collected on those wells which tap the 200 to 400 meter aquifers yield $\mathrm{Na}-\mathrm{K}-\mathrm{Ca}$ calculated temperatures which are higher than their corresponding measured values. For example, Arizona Electric Power Cooperative, Inc. (AEPCO) Well \#4, (D-16-24) 10ac has a bottom hole temperature of $40.4^{\circ} \mathrm{C}$ and a $\mathrm{Na}-\mathrm{K}-\mathrm{Ca}$ calculated reservoir temperature of $105^{\circ} \mathrm{C}$. The calculated temperature does not absolutely guarantee either a maximum or minimum expected reservoir temperature, nor does it attempt to answer the questions of how deep or extensive is the reservoir.

\section{Conclusions}

1. Twenty-one wells and springs within the Willcox Basin have reported temperatures in excess of $300^{\circ} \mathrm{C}$. A complete inventory of the entire water well system will no doubt encounter many more such wells.

2. Normal temperature gradient for the basin is approximately $34^{\circ} \mathrm{C} / \mathrm{km}$. Deeper portions of the basin should, therefore, contain waters within the 50 to $150^{\circ} \mathrm{C}$ range.

3. Abnormal temperature gradients occur in areas which are bounded by gravity lows or inferred deep structures. Such features may provide source and communication to the aquifers which display the higher heat gradients.

4. Areas of geothermal interest are: 1) the Stewart district, 2) the zone between Cochise and Pearce, and 3 ) 
the Kansas Settlement area.

5. In general, the poorest quality waters occur at shallow depths near the present location of the Willcox playa. Common salt and fluorine appear to be the most prevalent contaminates in the ground waters. 6. Additional studies of the existing water wells may help to further delineate the size and thermal characteristics of this geothermal resource area. 


\section{WATER SUPPLY AND UTILIZATION}

The Willcox Basin is a closed, deep alluvial basin containing a large volume of water. The basin is about $26 \mathrm{~km}$. wide, $80 \mathrm{~km}$. long, and about $2.4 \mathrm{~km}$. deep. The main water-bearing portion of the Willcox basin covers about 2,072 square $\mathrm{km}$; about $300 \mathrm{~m}$. of the uppermost part of the basin fill is now used for local water supply. Deep wells drilled in the area have encountered water under pressure at depths to about 1,200 m., and, undoubtedly, the entire waterbearing series is saturated. The deepest well in the basin was $2,070 \mathrm{~m}$. deep and did not reach bedrock. Therefore, the basin's depths have been inferred from gravity measurements (Aiken, 1978). These data suggest a depth of about $2,440 \mathrm{~m}$. or more to the unconformity between older intrusives and late Tertiary volcanics and interbedded alluvial deposits. Table V-1 presents a summary of reservoir conditions.

The waterbearing materials consist of a thick upper section of sediments including lake bed, alluvial fan, and aeolian deposits, and a lower section of mostly volcanic and some sedimentary rocks. The upper sediments also probably contain a small amount of interbedded volcanic ash; the boundary between the two units is probably gradual. For computational purposes, thicknesses and areas of the 


\section{Table V-1. Wilicox-Sulphur Springs Valley}

$\begin{array}{lcccc}\text { Sediment Type } & \text { Thickness } & \text { Area } & \text { Porosity } & \text { Speciflc Yleld } \\ \text { Nonvolcanic } & 1,370 \mathrm{~m} & 1,800 \mathrm{~km}^{2} & .21 & .01 \\ \text { Volcanic } & 1,070 \mathrm{~m} & 2,080 \mathrm{~km}^{2} & .10 & .005\end{array}$

Volume of basin sediments $\ldots \ldots \ldots \ldots \ldots \ldots \ldots \ldots \ldots \ldots 3.2$ Million $\mathrm{hm}^{3}$ Total water In storage ................... 530 Thousand $\mathrm{hm}^{3}$ Recoverable water $\ldots \ldots \ldots \ldots \ldots \ldots \ldots \ldots \ldots \ldots \ldots$ Thousand $\mathrm{hm}^{3}$ Fresh water in upper $1,000^{\prime} \ldots \ldots \ldots \ldots \ldots \ldots \ldots . . \ldots \ldots$ Thousand $\mathrm{hm}^{3}$ Net water $\ldots \ldots \ldots \ldots \ldots \ldots \ldots \ldots \ldots \ldots \ldots \ldots \ldots \ldots \ldots \ldots$ Thousand $h^{3}$ 
units are based on well log information and gravity data.

Porosity and specific yield of the two units were estimated from inspection of 1ithologic logs to compute both the volume of water in storage and the net recoverable water for the basin. The porosity values chosen are $20 \%$ for the upper sedimentary sequence and $10 \%$ for the lower volcanic-sedimentary sequence. A specific yield value of 1\% was chosen for the lower waterbearing sequence, because, in general, volcanic rocks have low capacities to store and transmit water. Using the stated assumed values of porosity and specific yield, the water stored in the basin is about 500 thousand cubic hectometres, and the net recoverable water, after agricultural and municipal use in the upper $300 \mathrm{~m}$. is subtracted, amounts to 25 thousand cubic hectometres. In actual practice, specific gield of sedimentary units may approach $10 \%$ over the long term, so the long term value of recoverable water may be greater. These estimates represent a conservative volume of water, if geologic conditions are relatively uniform within the basin. Limitations of the data include lack of precise and detailed information on the thickness of the waterbearing sequence, and lack of detailed information on the proportion of volcanic rocks within the basin. For example, if the basin is much deeper than assumed, the volume of water in storage would be greater. In a similar fashion, if the actual proportion of volcanic rocks is smaller and 
basin-fill sediments are greater in volume, the volume of water would be greater than shown. The net recoverable water would increase over the long term because of very slow drainage out of the surrounding sediments. Precise estimates on porosity and yield depend on the results of geological research not yet conducted. The estimates of this report reflect minimum, expected conditions, with the assumption that actual values are most likely equal to or greater than the estimates. 
VI. ENVIRONMENTAL ASPECTS

\section{A. Genera1}

So far the investigation of the W1llcox Basin has not disturbed the environment. Field work involved location and sampling of existing water wells, irrigation wells, seeps and springs.

Should additional work in the area be required, it probably would involve surface disturbance. Additional wells, especially the deeper ones, would have to be sampled. Geophysical techniques, such as close-spaced gravity determinations, may be needed to better define the extent of the basin. No surface disturbance is involved in such a survey. If heat flow drilling is deemed necessary, the judicious selection of drill site or sites will minimize local impact. Since the area is currently being farmed, there is the likelihood of one or more drill sites being located in or adjacent to farm land. The impact on the natural or farm environment would be minimal and of short duration.

Should an economic resource area or areas be delineated within the Willcox Basin, appropriate care and concern will be taken to extract the geothermal heat and water. The problems associated with the development of geothermal resources within a heavily farmed area should be akin to those of developing new irrigation wells which do not contain 
the thermal energies. Brine and/or salt may be a by-product of the upgraded waters. Disposal or sale of these by-products will depend upon their composition and quantity. Speculation on removal of these products from the surface environment will have to be deferred until such time as the chemical composition of the resource water is known.

Withdrawal of ground waters may also cause local subsidence. This is true whether the waters are thermal or not. In this respect, the development of the resource for its water content is no different than if one were to develop shallow irrigation wells of equal capacity. The main difference between the geothermal waters and the currently exploited irrigation waters (other than their thermal characteristics) is that the geothermal waters are deeper. 
Selected References

Aiken, C.I.V., and Sumner, J.S., 1974, A geophysical and geological investigation of potentially favorable areas for petroleum exploration in southeastern Arizona: Arizona Oil and Gas Commission, Report 3, 40 p.

Aiken, C.L.V., 1975, Residual Bouguer gravity anomaly map of Arizona: Tucson, Department of Geosciences, University of Arizona, 1 sheet.

Aiken, C.L.V., 1978, Gravity and aeromagnetic anomalies of southeastern Arizona: New Mexico Geological Society Guidebook, 29th Field Conference, Land of Cochise, p. 301-313.

Arizona Highway Department, 1977, Land Status, 1:62,500, 9 sheets.

Arizona Well Records Company, 1961, Arizona Well Records.

Brown, S.G., Schumann, H.H., Kister, L.R., and Johnson, P.W., 1963, Basic ground-water data of the Willcox basin, Graham and Cochise Counties, Arizona: Arizona State Land Department, Water Resources Report 14,93 p.

Brown, S.G., and Schumann, H.H., 1969, Geohydrology and water utilization in the Willcox basin, Graham and Cochise Counties, Arizona: U.S. Geological Survey Water-Supply Paper 1857-F, $32 \mathrm{p}$.

Cooper, J.R., 1959, Some geologic features of the Dragoon quadrangle, Arizona: Arizona Geological Society Guidebook II Southern Arizona, p. 139-145.

Cooper, J.R., 1960a, Reconnaissance geologic map of southeastern Cochise County: U.S. Geological Survey Min. Inv. Field Studies Map MF-213.

Cooper, J.R., 1960b, Reconnaissance map of the Willcox, Fisher Hills, Cochise, and Dos Cabezas quadrangles, Cochise and Graham Counties, Arizona: U.S. Geological Survey Min. Inv. Field Studies Map MF-231.

Creasey, S.C., and Krieger, M.H., 1978, Galiuro volcanics, Pinal, Graham, and Cochise Counties, Arizona: J. Research, U.S. Geological Survey, Vol. 6, p. 115-131. 
Decker, E.R., Cook, F.A., Ramberg, I.B., and Smithson, S.B., 1975, Significance of geothermal and gravity studies in the Las Cruces Area: New Mexico Geological Society Guidebook, 26th Field Conference, Las Cruces County, p. 251-259.

Druitt, C.E., 1976, Mean annual temperature map, State of Arizona: Arizona $0 i l$ and Gas Conservation Commission GT-Z.

Dutt, G.R., and McCreary, T.W., 1970, The quality of Arizona's domestic, agricultural, and industrial waters: University of Arizona, Tucson, Agricultural Experiment Station Report No. 256,83 p.

Eberly, D., and Stanley, B., Jr., 1978, Cenozoic stratigraphy and geologic history of southwestern Arizona: Geological Society of America Bulletin, Vol. 89, p. 921-940.

Fournier, R.O., and Truesdell, A.H., 1973, An empirical Na-KCA geothermometer for neutral waters: Geochem et Cosmochim Acta, Vol. 37, p. 1255-1275.

Giardina, Salvatore, Jr., and Conley, J.N., 1978, Thermal gradient anomalies in southern Arizona: Arizona Oil and Gas Conservation Commission Report of Inv. 6, $49 \mathrm{p}$.

Heindl, L.A., and DeCook, K.J., 1952, Principles of ground water occurrence, in Halpenny, L.C., and others, Ground water in the Wilicox basin, Graham and Cochise Counties, Arizona: U.S. Geological Survey Hydrol. Inv. Atlas HA-214.

Hem, J.D., 1970, Study and interpretation of the chemical characteristics of natural water: U.S. Geological Survey Water-Supply Paper 1473, 363 p.

Kellogg, L.O., 1906, Sketch of the geology and ore deposits of the Cochise mining district, Cochise County, Arizona: Econ. Geol., Vol. 1, p. 651-659.

Kister, L.R., Brown, S.G., Schumann, H.H., and Johnson, P.W., 1966, Maps showing fiuoride content and salinity of ground water in the Willcox basin, Graham and Cochise Counties, Arizona: U.S. Geological Survey Hydrol. Inv. Atlas HA-214, 2 sheets.

Long, Austin, 1966, Late Pleistocene and recent chronologies of playa lakes in Arizona and New Mexico: Tucson, University of Arizona unpub. Ph.D. Thesis, $141 \mathrm{p}$. 
Marjaniem1, Darwin, K., 1969, Geologic history of an ashflow sequence and its source area in the Basin and range Province of southeastern Arizona: Tucson, University of Arizona, unpub. Ph.D. Thesis, $176 \mathrm{p}$.

Meinzer, O.E., and Kelton, F.C., 1913, Geology and water resources of Sulfur Spring Valley, Arizona: U.S. Geological Survey Water-Supply Paper 320, p. 9-213.

Pine, G.L., 1963, Sedimentation studies in the vicinity of Willcox Playa, Cochise County, Arizona: Tucson, University of Arizona unpub. M.S. Thesis, $38 \mathrm{p}$.

Robinson, R.C., 1965, Sedimentology of beach ridge and nearshore deposits, pluvial Lake Cochise, southeastern Arizona: Tucson, University of Arizona unpub. M.S. Thesis, $111 \mathrm{p}$.

Sauck, W.A., and Sumner, J.S., 1970, Residual aeromagnetic map of Arizona: Tucson, University of Arizona Press, 1 sheet.

Scarborough, R.B., and Peirce, H.W., 1978, Late Cenozolc basins of Arizona: New Mexico Geological Society Guidebook, 29th Field Conference, Land of Cochise, p. 253-259.

Schreiber, J.F., Jr, and others, 1972 , Sedimentologic studies in the Wilicox Playa area, Cochise County, Arizona: in Playa Lake Symposium, Int. Cent. Arid Semi-Arid Land $\overline{S t}$. Publ., No. 4, p. 133-184.

Schreiber, J.F., Jr., 1978, Geology of the Willcox Playa, Cochise County, Arizona: in New Mexico Guidebook, 29th Field Conference, p. 277-282.

Texas Instruments, Inc., 1978, Aerial Radiometric and Magnetic Reconnaissance Survey of Portions of Arizona - New Mexico, Final report: GJBX Open File 23, Vol. 2.

U.S. Geological Survey, 1959, Douglas AMS NH 12-3, 1:250,000.

U.S. Geological Survey, 1954, Silver City AMS NH 12-12, $1: 250,000$.

U.S. Geological Survey, 1956, Nogales AMS NH 12-2, 1:250,000.

U.S. Geological Survey, 1956, Tucson AMS NH 12-11, 1:250,000. 
U.S. Geological Survey, 1979, WATSTORE Computer Tape File. University of Arizona, 1979, Agricultural Extension Service, Open File. 


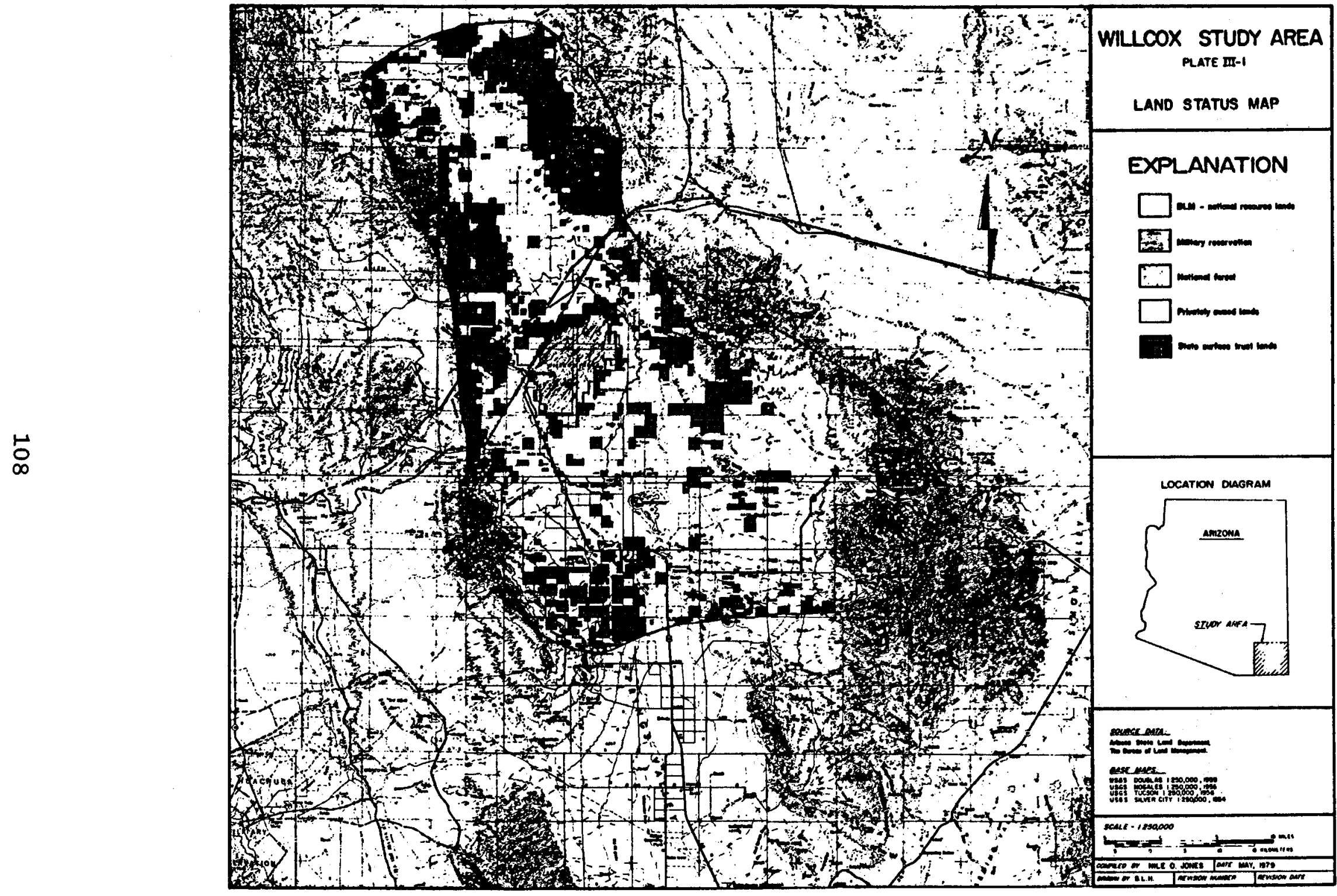




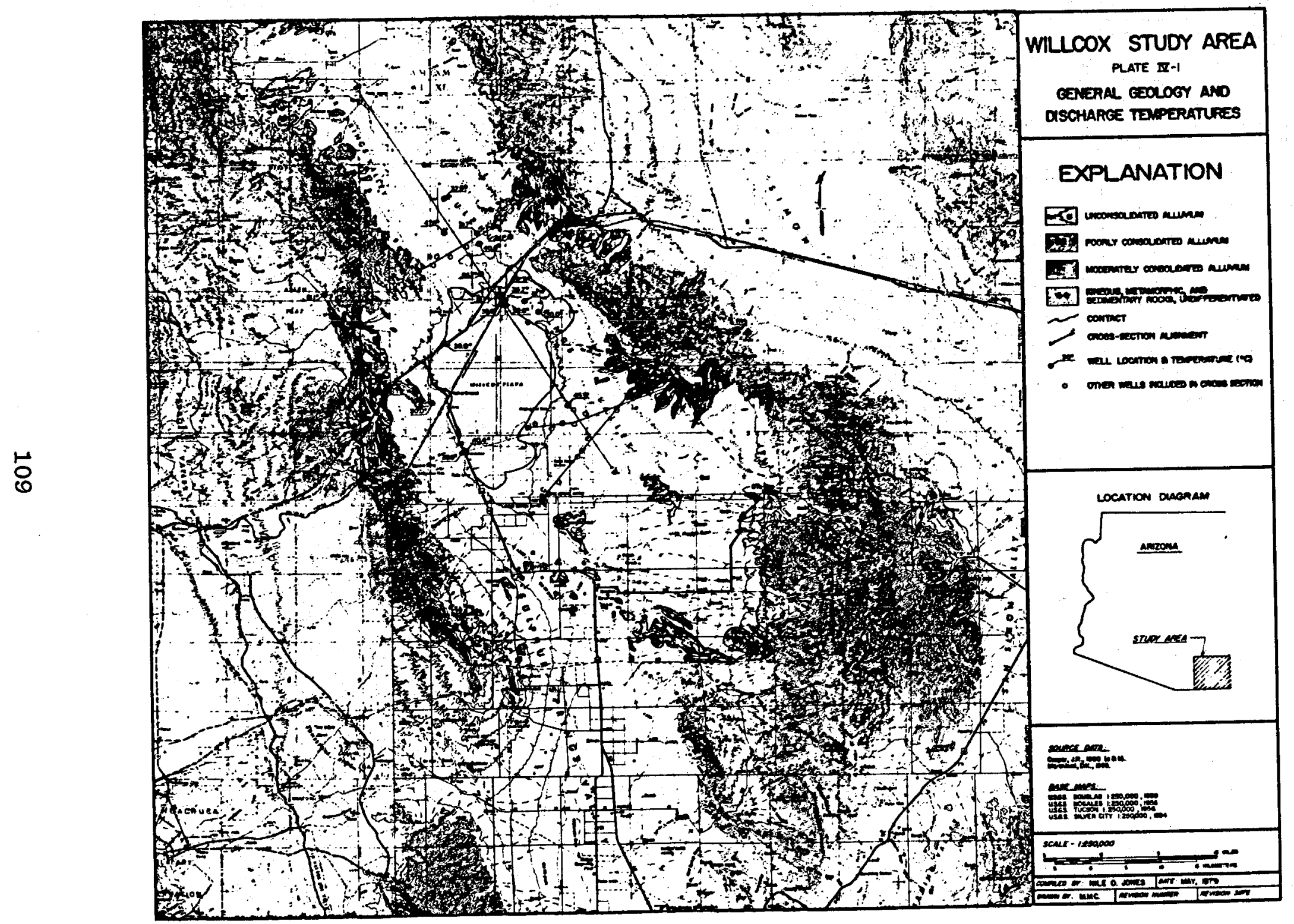




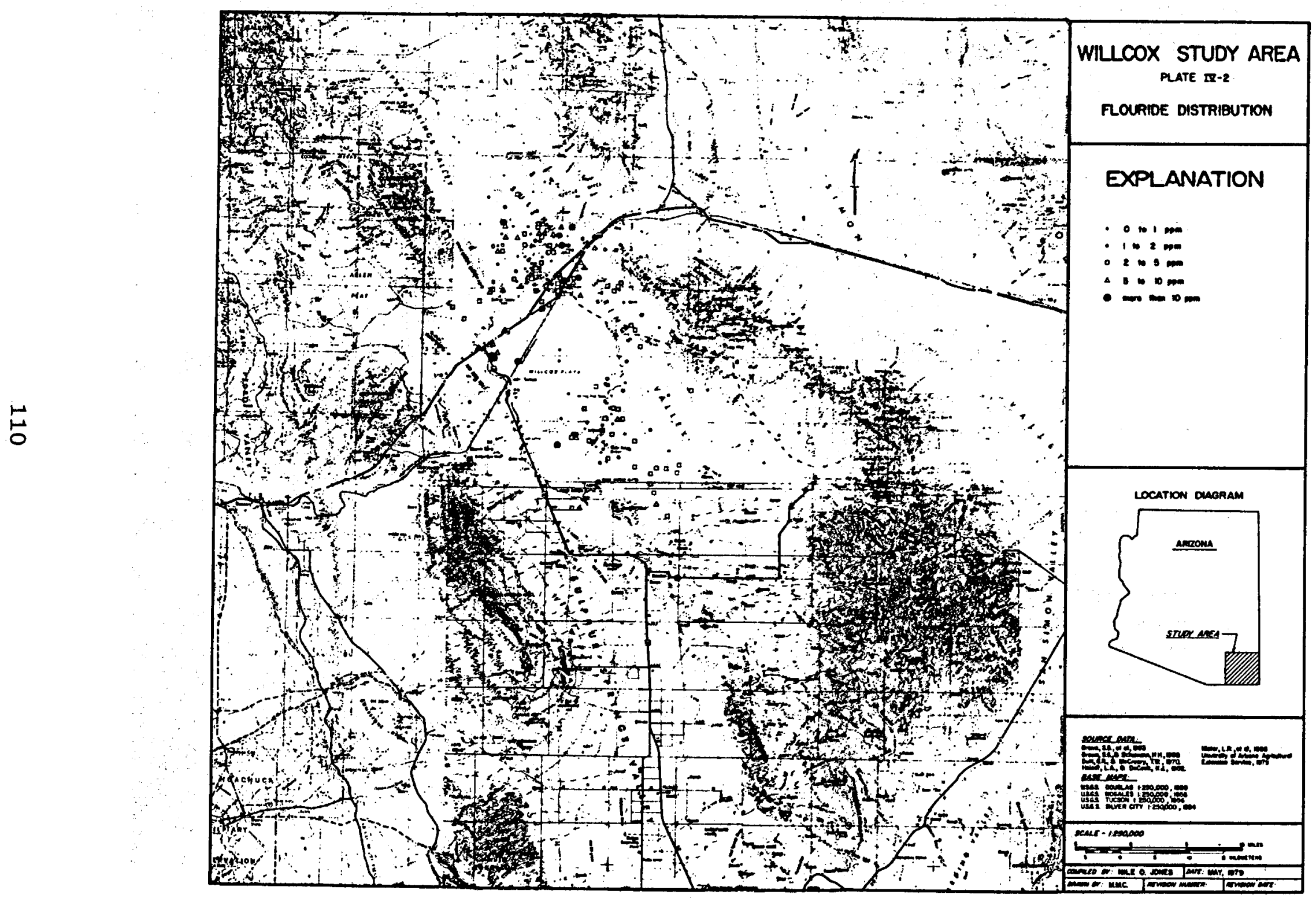

C 


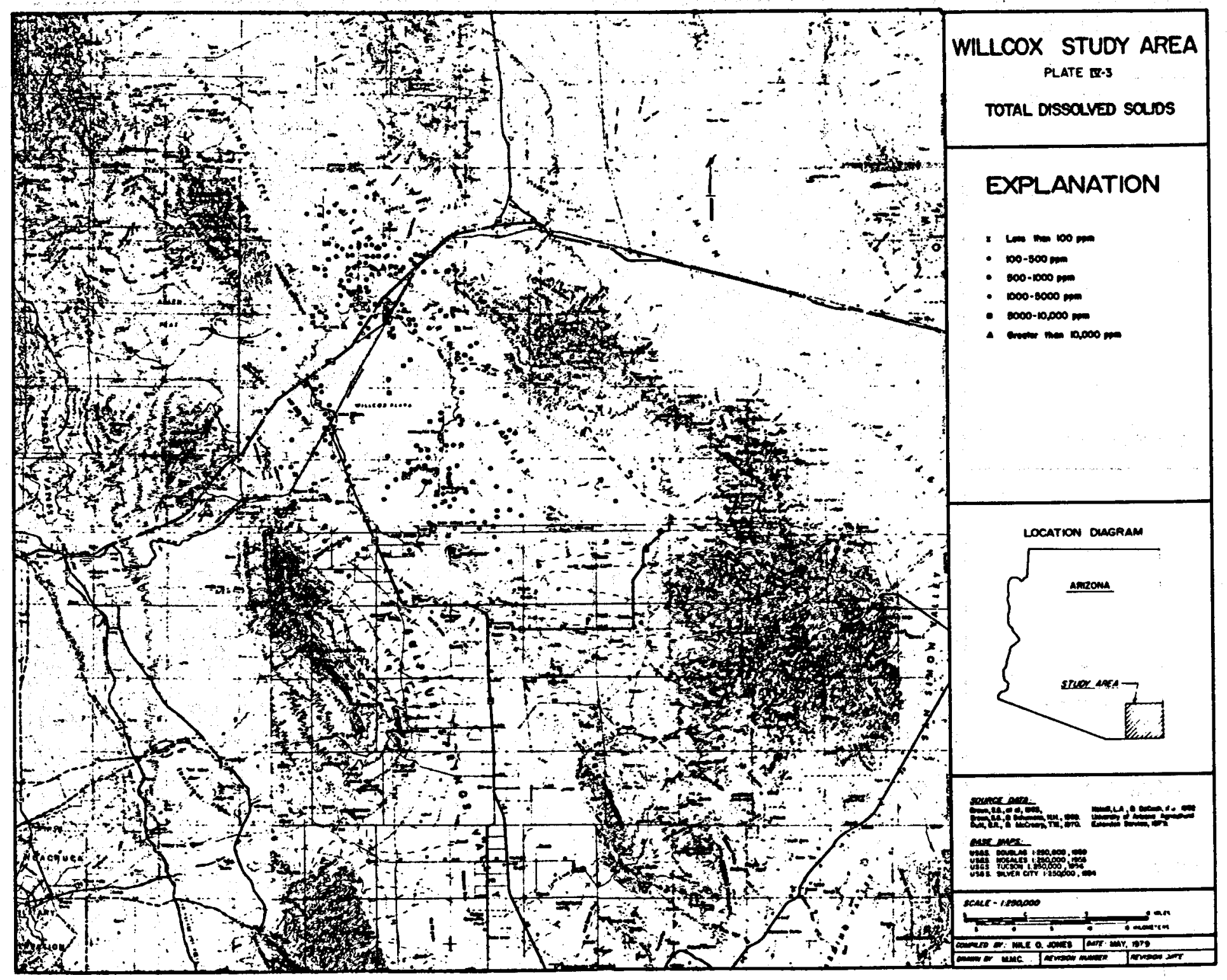




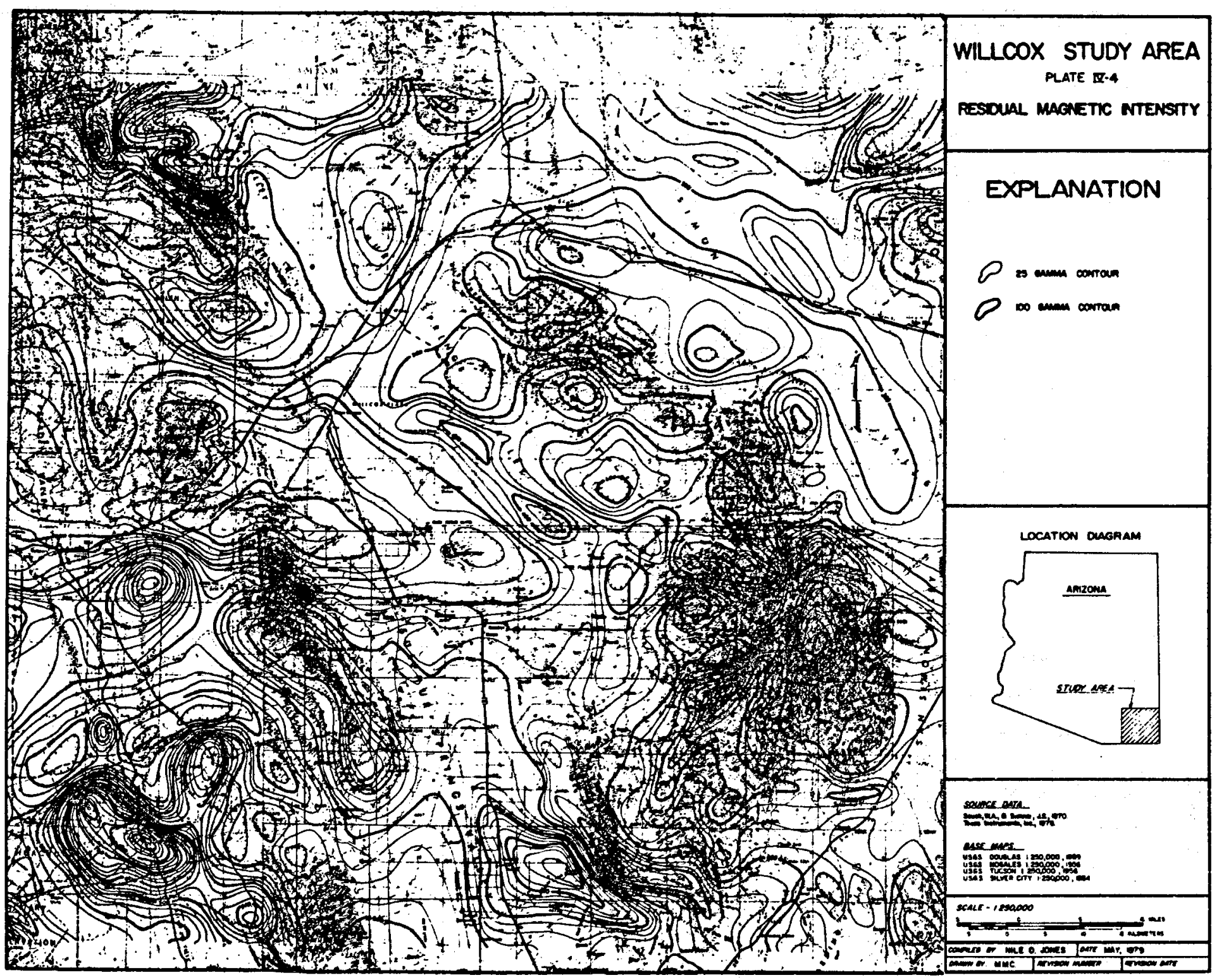

c. 


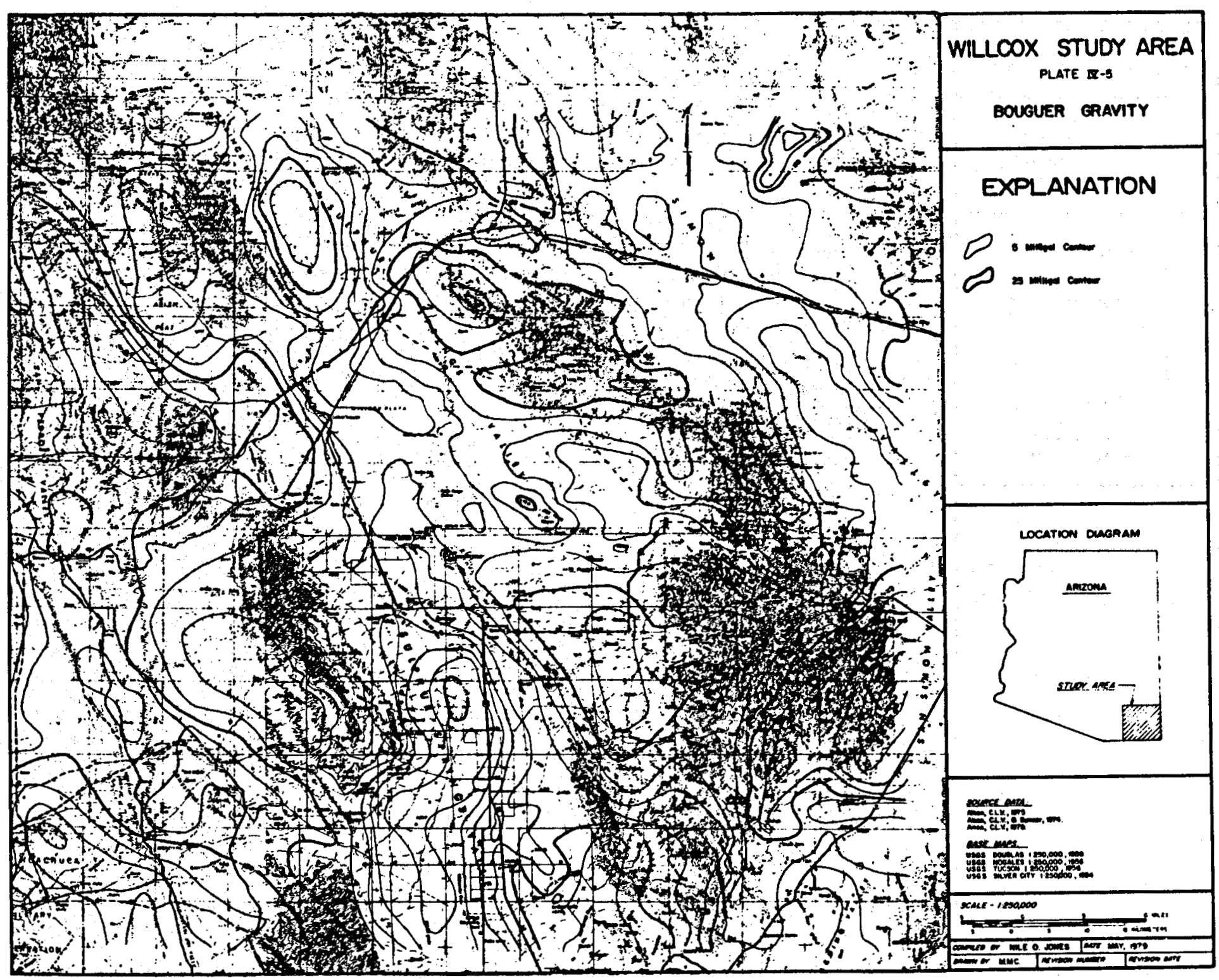




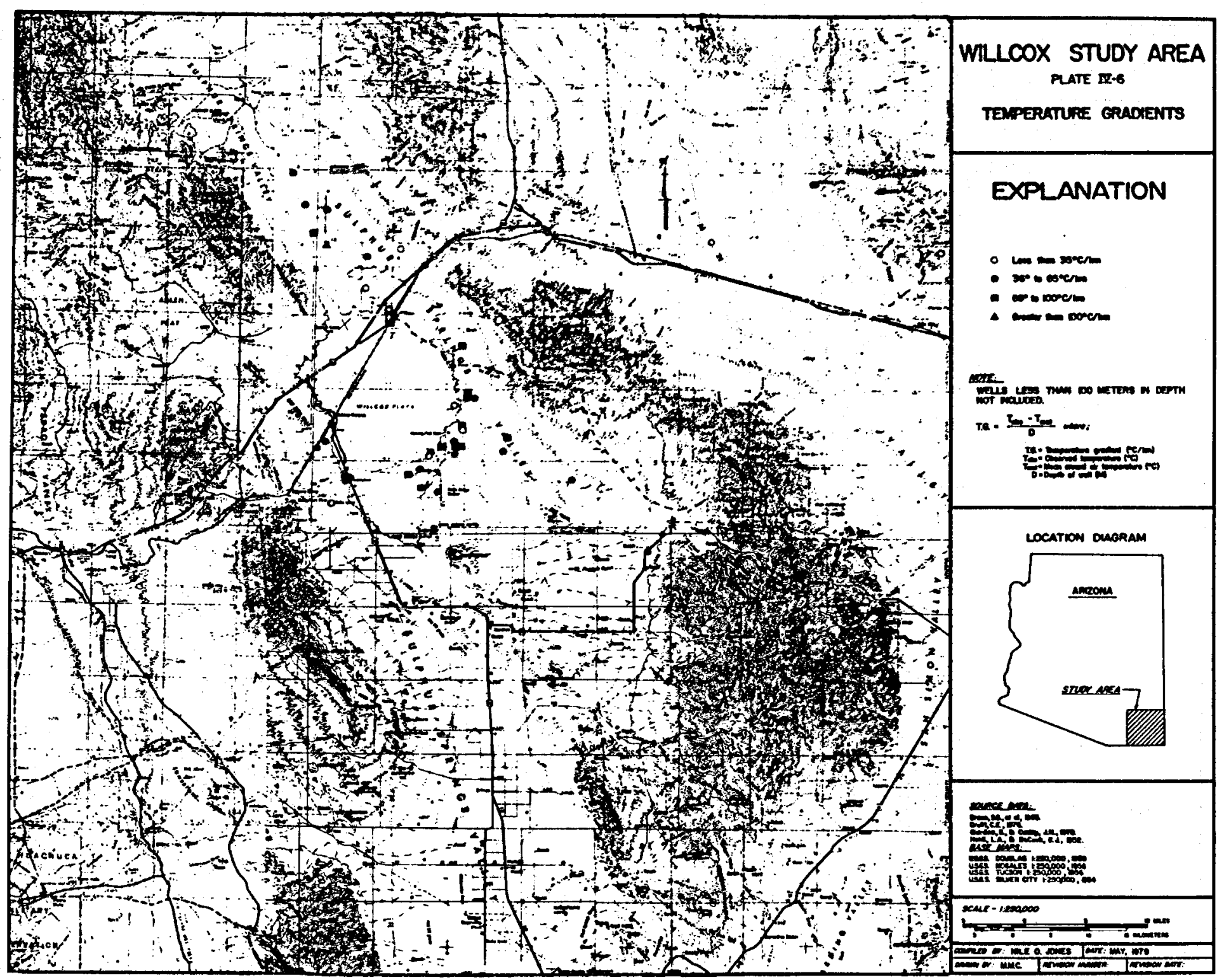




\title{
PRELIMINARY GEOTHERMAL ASSESSMENT OF THE HYDER AREA
}

\author{
Nile 0 . Jones \\ with a section in hydrology by \\ Alice Campbell \\ BUREAU OF GEOLOGY AND MINERAL TECHNOLOGY \\ GEOLOGICAL SURVEY BRANCH \\ GEOTHERMAL GROUP

$$
\text { July, } 1979
$$ \\ PREPARED FOR THE \\ U.S. DEPARTMENT OF THE INTERIOR, \\ BUREAU OF RECLAMATION IN CONJUNCTION \\ WITH THE U.S. DEPARTMENT OF ENERGY, \\ DIVISION OF GEOTHERMAL ENERGY \\ UNDER CONTRACT EG-77-S-02-4362
}




\section{INTRODUCTORY MATERIAL}

A. Location and Access

The Hyder area consists of the Palomas Plain, Hyder Valley, and the northern portion of the Sentinel plain, Part of the area is in western Maricopa County and the remainder is in Yuma County (Figure I-1). The Gila River corsses the south-central portion of the area in an east to west direction on its way to the colorado River. Highway 80 parallels the river to connect the agriculture communities of Gila Bend and Yuma. Highway 80 is also the major route to southern California. Secondary dirt roads provide access to the numerous farms in the southern portion of the Palomas Plain and Hyder Valley.

B. Local Support

Numerous contacts were established with the owners and operators of the farms in the area. They provided access to their wells and expressed enthusiasm in the goals for this project. Special recogniation goes to Nick Kondora of Whitewing Ranch and Paul Manera, P.E., for their time and interest. 


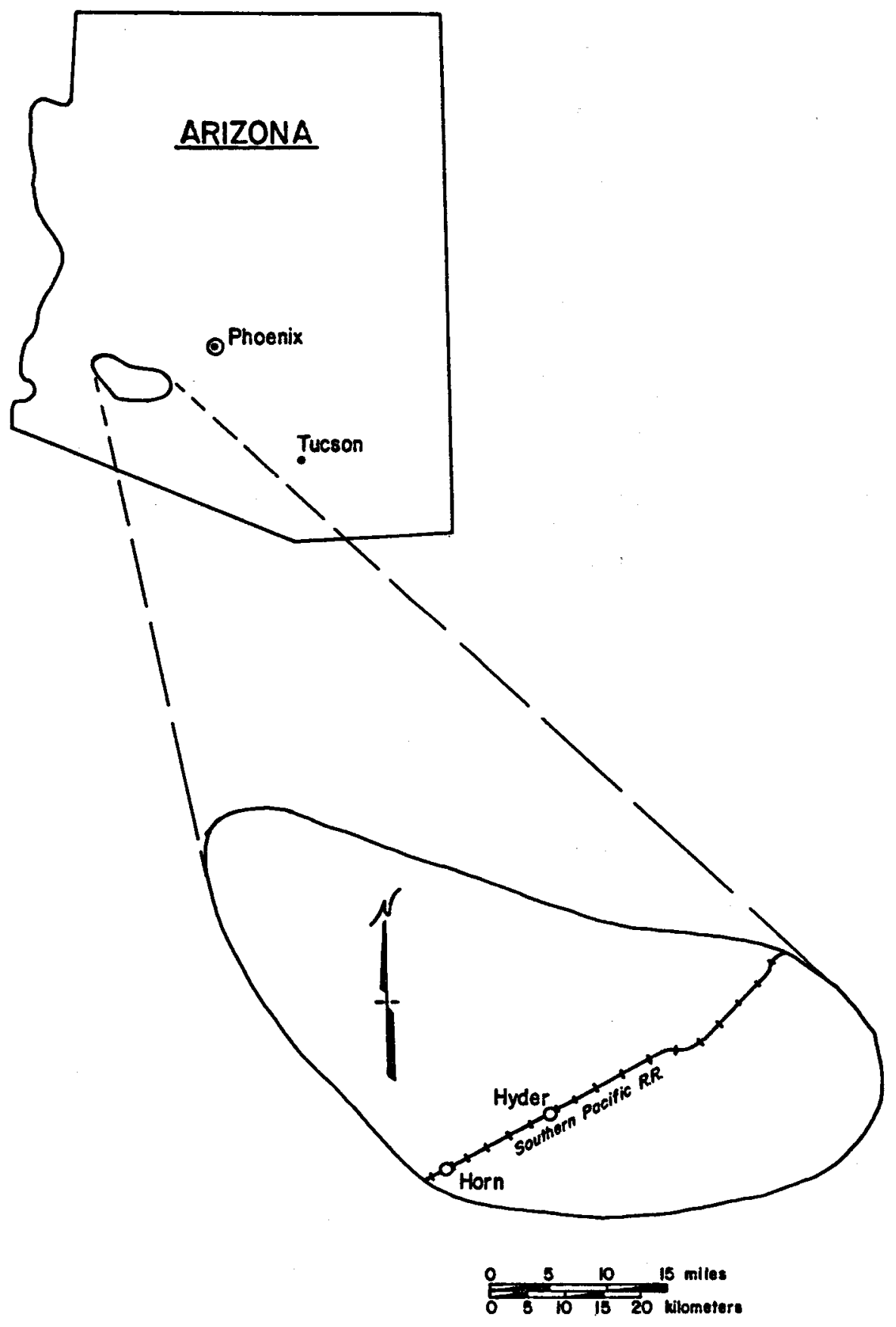

FIGURE I-1. Location of the Hyder Study Area, Arizona. 
II. SUMMARY AND RECOMMENDATIONS

A. Development of Potential Resources

The water balance of the area was evaluated by examining the water in storage and the potential for recharge. Annual precipitation is approximately 6 inches $(13.8 \mathrm{~cm})$ per year. Much of this water is returned to the atmosphere through evapotraspiration.

Total volume of water velow $300 \mathrm{~m}$ is $60,600 \mathrm{hm}^{3}$. Recoverable water below the same datum is set at $23,500 \mathrm{hm}^{3}$. Water from existing wells generally contain less than $5,000 \mathrm{mg} / 1$ dissolved solids. No known wells contain more than $10 \mathrm{mg} / \mathrm{l}$ fluoride. The dissolved solids and salt content of a hydrothermal reservoir would no doubt contain higher values, but probable well not exceed $20,000 \mathrm{mg} / 1$. Using a normal temperature gradient of $35^{\circ} \mathrm{C} / \mathrm{km}$ for the basin, a temperature of $150^{\circ} \mathrm{C}$ would be achieved at about 3.5 kilometers. Abnormal temperature gradients north of Baragan Mountain, south of Horn, and south of Turtleback Mountain suggest $150^{\circ} \mathrm{C}$ temperatures could be achieved at depths of less than 2.5 kilometers. Substantiation of these projected temperatures should be undertaken as a first step in the development of this area. 
III. LAND STATUS

The Hyder Valley - Palomas Plaon study area encompasses nearly $1,200 \mathrm{~km}^{2}$ of basin material. The total watershed is about $2,800 \mathrm{~km}^{2}$ (Map III-1). Table III-1 is a breakdown of the land situation by major land holders.

Table III-1 Land Status of Hyder Valley - Palomas Plain

Owner or Trust Group

Private Ownership

State of Arizona Trust

BLM Resource Lands

Military Proving Grounds

Kofa Game Range

\begin{tabular}{|c|c|}
\hline Area $\left(m i^{2}\right)$ & Area $\left(\mathrm{km}^{2}\right)$ \\
\hline 118. & 305.5 \\
\hline 142.9 & 370.1 \\
\hline 587.3 & 1521.1 \\
\hline 216. & 559.4 \\
\hline 22 & 57 \\
\hline 1086.2 & 2812.1 \\
\hline
\end{tabular}

Approximately 54\% of the land is under BLM juristiction, $13 \%$ is state land and $11 \%$ is privately owned. The remaining is held by the military or is in the Kofa Game Range. 
IV. RESOURCE EVALUATION

A. Introduction

A review of existing geological, hydrological and temperature data from the Dateland-Hyder area was undertaken. This was judged to be the first step in assessing the area's geothermal potential. Additional information was gathered from firsthand field observations and discussions with the local population.

Temperature measurements and chemical geothermometry suggest three areas where $40^{\circ}$ to $100^{\circ} \mathrm{C}$ waters may be found at depths of 500 to 1,000 meters. Projection of thermal gradients indicate $200^{\circ} \mathrm{C}$ temperatures may be encountered at depths as shallow as 2,000 meters. Such a projection assumes continuation of the most favorable thermal gradients. Additional sitespecific work will be required to delineate these more favorable areas.

B. Previous Work

Geological and hydrological studies on parts of the area or adjacent areas include those of Ross (1922, 1923), Bryan (1925), Wilson, (1933), Armstrong and Yost (1958), Ibrahim (1962), and Weist, Jr., (1965). Unpublished hydrology or water-supply reports on areas within the region include those of Babcock, Brown and Heim (1947), Babcock and Kendall (1948), Halpenny and others (1952), Johnson and Cahill (1954), and Cahill and Wolcott (1955). Regional gravity and aeromagnetic studies have been conducted by Peterson (1968), Sauck and Sumner (1970), and Aiken (1975).. Water chemistry from selected 
wells came from Smith and others (1963), the U.S. Geological Survey Water Resources Open-Files (WATSTORE 1978) and those collected during this study.

\section{Geology}

The geologic units of the Hyder-Dateland area can be divided into the bedrock mountain blocks and the basin-fill sediments. Although much of the water will be contained within the basin sediments, it is important to recognize the variey of rock types and ages represented in the bedrock mountain blocks.

1. Bedrock and Mountain Blocks. Precambrian schist, gneiss and granite is exposed in portions of the Tank and Palomas Mountains as well as in the Aztec Hills (Map IV-1). Wilson (1960) placed a Mesozoic date on many of these units, but isotopic dating indicates a much older date of emplacement. Table IV-1 is a listing of important age dates of volcanic units located in or immediately adjacent to the Hyder study area. The genissic granite from the Exxon State well (14)-1 shows a Mesozoic recrystallization date of a Precambrian granite. Extrusive volcanics in the Hyder area are Cenozoic in age with the youngest being Pliocene.

All Precambrian exposures have been extensively fractured and faulted. Quartz-dominated pegmatite dikes and veins may be found throughout these older units, but none were observed in the younger volcanics. 
Rock Type or

Formation

Rhyodacite

Basalt

Rhyolitic Tuff

Basaltic Andesite

Basaltic Andesite

Basaltic Andesite

Andesite

Basaltic Andesite

Leucocratic

Rhyolite

Basalt

Basalt

Basalt

Rhyolitic Tuff

Andesite

Gneissic Granite
Radiometric Age Method,

Mineral Dated

$\mathrm{K}-\mathrm{Ar}$, hornblende

lat $33^{\circ} 35^{\prime} 10^{\prime \prime} \mathrm{N}$, long $114^{\circ} 02^{\prime} 35^{\prime \prime} \mathrm{W}$

lat $33^{\circ} 01^{\prime} 03^{\prime} \mathrm{N}$, long $_{112^{\circ}}, 59^{\prime} 58^{\prime \prime} \mathrm{W}$

1at $33^{\circ} 16^{\prime} 23^{\prime \prime} \mathrm{N}, 1$ ong $113^{\circ} 26^{\prime} 51^{\prime \prime} \mathrm{W}$

lat $33^{\circ} 11^{\prime} 40^{\prime \prime} \mathrm{N}$, long $112^{\circ} 48^{\prime} 15^{\prime \prime} \mathrm{W}$

lat $33^{\circ} 20^{\prime} 24^{\prime \prime} \mathrm{N}$, long $112^{\circ} 47^{\prime} 40^{\prime \prime} \mathrm{W}$

lat $33^{\circ} 25^{\prime} 42^{\prime \prime} \mathrm{N}$, long $112^{\circ} 52^{\prime} 30^{\prime \prime} \mathrm{W}$

lat $33^{\circ} 25^{\prime} 37^{\prime \prime} \mathrm{N}$, long $112^{\circ} 57^{\prime}$, W

1at $33^{\circ} 23^{\prime} 20^{\prime \prime} \mathrm{N}$, long $112^{\circ} 49^{\prime} 48^{\prime \prime} \mathrm{W}$

lat $33^{\circ} 08^{\prime} 11^{\prime \prime} \mathrm{N}$, long $113^{\circ} 23^{\prime} 52^{\prime \prime} \mathrm{W}$

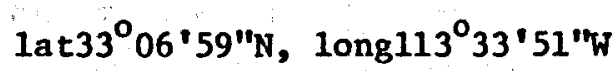

lat32056 $06^{\prime \prime} \mathrm{N}, 1^{\circ}{ }^{\circ} 113^{\circ} 18^{\prime} 05^{\prime \prime} \mathrm{W}$

lat $32^{\circ} 33^{\prime} 03^{\prime \prime} \mathrm{N}$, long112052 ' $43^{\prime \prime} \mathrm{W}$

1at $32^{\circ} 47^{\prime} 17^{\prime \prime} \mathrm{N}$, long $114^{\circ} 06^{\prime} 19^{\prime \prime} \mathrm{W}$

T3S, R11W, Sec. 25db
Reference, Sample, Any Comments

Miller \& McKee (1971)

Eber1y \& Stanley (1978)

Eberly \& Stanley (1978)

Shoustra et al. (1976)

Shoustra et al. (1976)

Shoustra et al. (1976)

Shoustra et al. (1976)

Shoustra et al. (1976)

Eberly \& Stanley (1978

Eberly \& Stanley (1978)

Eberly \& Stanley (1978)

Eberly \& Stanley (1978)

Eberly \& Stanley (1978)

Eberly \& Stanley (1978); Andesite from Exxon State Well

(14)-1, 299-235 m; gnelssic granite, $771-777 \mathrm{~m}$, younger date represents recrystalization in Jurassic time. 
2. Basin Sediments. The basin-fill sediments in the Hyder area are similar to those in other basins in southern Arizona. There are mixtures of fine to medium-grained clastics, coarser sands and conglomerates. All sediments are believed to have been deposited since late Cretaceous-early Tertiary time (Eberly and Stanley, 1978; Scarborough and Peirce, 1978).

The sediments are subdivided into an older Unit $I$ and a younger Unit II as proposed by Eberly and Stanley (1978) with the boundary marked by one or more of the following conditions: 1) the first volcanic tuff or basalt flow of mid-Miocene age (13 m.y.); 2) a wide-spread unconformity surface associated with mid-Miocene block-faulting; 3) thick conglomerate sequences associated with this period of block-faulting;

4) the change from unconsolidated to indurated sediments and 5) tilting of the materials that comprise Unit I. Figure IV-1 illustrates this two-fold classification.

Unit I rests directly on a major unconformity which separates the Tertiary sediments, volcanics and reworked volcanic detiritus from the pre-Tertiary bedrock. Unit I includes all basin-fill rocks deposited following the Laramide orogeny, approximately $53 \mathrm{~m} \cdot \mathrm{y}$. ago, and the time of the first significant movements following the mid-Miocene volcanic episode of about $18-20 \mathrm{~m} . \mathrm{y}$. ago (see Table IV-1). The basal section is generally arkosic with interbedded fanglomerates. Hematite often stains these sediments a distinctive reddishbrown. Deeper portions of the basin may contain several 

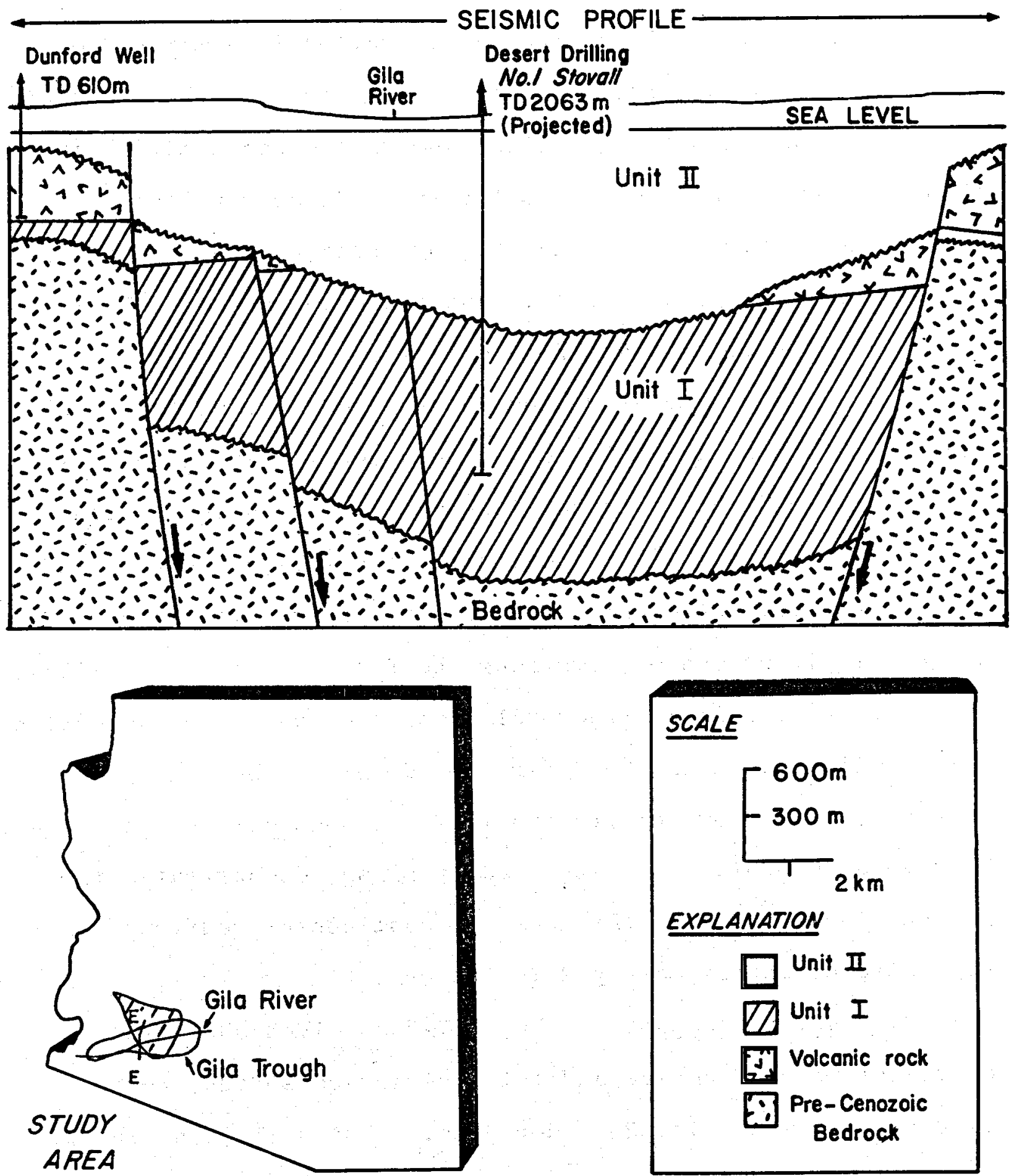

EXPLANATION

Unit II

77 Unit I

[j] Volcanic rock

E: Pre-Cenozoic Bedrock

FIGURE IV-I: LOCATION MAP AND CROSS SECTION ACROSS THE GILA TROUGH (FROM EBERLY AND STANLEY, 1978). 
hundred meters of this coarse clastic material.

Immediatoly overlying the basal section fis a mixture of mid-Tertlary tuffs, breccias, volcanic flows, reworked volcanic detritus, mudstones and gravels. Numerous unconformities in this section are attributed to the early-Miocene volcanic events and the interim basin and range readjustments. Unit I may be capped by basalt flows. Estimated thickness of Unit I is about 1,400 meters (see Figure IV-1).

Unit $I$ is characterized by interbedded continental'sand, gravel, silt and clay. Typically this section is unconsolidated, although the lower portions may contain some calcite or hematite comenting. Evaporites have not been reported in the literature, but high sulfate content from selected wells suggest their presence (Armstrong and Yost, 1958; Weist, 1965).

Figure IV-1 is a structural cross section across a portion of the Gila trough in the Hyder area developed by Eberly and Stanley (1978) from seismic profiles and deep oil test drilling. This seismic profile, constructed by Exxon, demonstrates the graben structure. The thickness of continental sediments is estimated at approximately 2,700 meters.

3. Water Chemistry. Maps IV-2 and IV-3 shows the distribution of fluoride and total dissolved solids, respectively, from wells in the Hyder area. Most wells contain more than $2 \mathrm{mg} / 1$ fluoride and about one-third of those sampled contain more than $5 \mathrm{mg} / 1$. No well is currently known to contain more than $10 \mathrm{mg} / 1$ fluoride. Recommended limits on fluoride in 
drinking water for this area is $1 \mathrm{mg} / 1$ or less, Table IV-2 (Hem, 1970). The higher concentrations of fluoride generally occur east of the line between Baragan Mountain and the Agua Caliente Mountains. No obvious variance in concentration can be seen along the axis of the Gila River.

Most wells within the area contain between 500 and 5,000 $\mathrm{mg} / 1$ dissolved solids. The few wells which exceed $5,000 \mathrm{mg} / 1$ are located near the Gila River. Less than 10 percent of the wells contain less than $500 \mathrm{mg} / 1$. The quantity of dissolved solids in the groundwater decreases away from the Gila River.

Chemical data for the water wells on the Whitewing ranch were provided by its manager, Mr. Nick Kondora. No appreciable change in overall water quality was noted between his 1974 values and those obtained during this survey. Except for $\mathrm{HCO}_{3}$, all 1974 values were within expected analytical error. Table IV-3 is a comparison of common ions from the 1974 and 1979 water chemistries. Fluoride, potassium, boron and silica were not evaluated in 1974 and nitrate was not included in the 1979 analyses. The presence of gypsum and halite in the basin is suspected because of the quantity of $\mathrm{SO}_{4}, \mathrm{Cl}, \mathrm{Na}$ and $\mathrm{Ca}$ in the water. Low values for $\mathrm{HCO}_{3}$ and $\mathrm{Mg}$ suggest low concentrations of calcite and dolomite in those portions of the section that have had recent ground-water movement.

4. Geophysics. State-wide aeromagnetic and gravity maps for Arizona have been compiled by the College of Geosciences, University of Arizona (Sauck and Sumner, 1970; Aiken, 1975). 
Table IV-2. Recommended limits of fluoride concentration

in drinking water (after Hem, 1970).

Annual average of maximum

daily air temperatures (OF)

$50.0-53.7$

$53.8-58.3$

$58.4-63.8$

$63.9-70.6$

$70.7-79.2^{2}$

$79.2-90.5$
Recommended control limits mg/1

Lower Optimum Upper

$0.9 \quad 1.2 \quad 1.7$

$\begin{array}{lll}0.8 & 1.1 & 1.5\end{array}$

$\begin{array}{lll}0.8 & 1.0 & 1.3\end{array}$

$0.7 \quad 0.9 \quad 1.2$

0.7

0.8

1.1

0.6

0.7

0.8

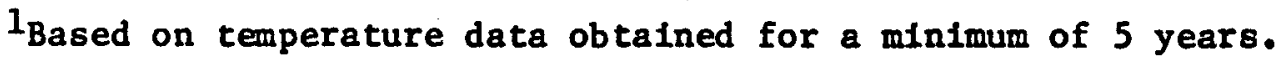

2 Temperature range for the Hyder area. 
Table IV-3. WHITEWING RAICH GROISD-" MSTER CHEMISTRY OF 1974 AND 1979

\begin{tabular}{|c|c|c|c|c|c|c|c|c|c|c|c|c|c|c|}
\hline \multirow[b]{2}{*}{ Well Na. } & \multicolumn{2}{|c|}{$\mathrm{Na}$} & \multicolumn{2}{|c|}{ Mg } & \multicolumn{2}{|c|}{$\mathrm{Ca}$} & \multicolumn{2}{|c|}{ Cl } & \multicolumn{2}{|c|}{$\mathrm{SO}_{4}$} & \multicolumn{2}{|c|}{$\mathrm{HCO}_{3}$} & \multicolumn{2}{|c|}{ TDS } \\
\hline & 174 & 72 & 174 & 79 & 174 & 179 & 174 & 179 & 174 & $\cdot 79$ & 174 & 179 & 174 & 179 \\
\hline Whitewing \# 1 & 320 & 407 & 22 & 50 & 285 & 220 & 860 & 1004 & 203 & 298 & 127 & 66 & 1854 & 2599 \\
\hline Whitewing $\# 2$ & 205 & 259 & 10 & 10 & 61 & 45 & 308 & 362 & 120 & 203 & 137 & 87 & 877 & 1067 \\
\hline Whitewing $\| 3$ & 215 & 291 & 15 & 16 & 85 & 62 & 380 & 411 & 146 & 275 & 127 & 76 & 1017 & 1345 \\
\hline Whitewing $\$ 5$ & 280 & 360 & 29 & 28 & 208 & 92 & 612 & 564 & 190 & 350 & 123 & 71 & 1562 & 1850 \\
\hline Whitewing $\# 23$ & 210 & 215 & 16 & 10 & 82 & 35 & 192 & 253 & 143 & 173 & 142 & 100 & 995 & 962 \\
\hline Whitewing 14 & 175 & 182 & 9 & 6 & 38 & 16 & 132 & 163 & 114 & 124 & 162 & 126 & 735 & 730 \\
\hline Whit ewing \#15 & 147 & 152 & 2 & 3 & 18 & 9 & 136 & 117 & 68 & 89 & 152 & 120 & 542 & 595 \\
\hline Whitewing 16 & 137 & 150 & 2 & 2 & 19 & 10 & 124 & 130 & 70 & 90 & 137 & 111 & 516 & 581 \\
\hline Whitewing $\$ 17$ & 143 & 142 & 2 & 2 & 14 & 7 & 188 & 211 & 60 & 81 & 137 & 105 & 493 & 483 \\
\hline Whitewing $\# 18$ & 157 & 177 & 3 & 4 & 27 & 19 & 172 & 219 & 90 & 94 & 123 & 95 & 603 & 734 \\
\hline Whitewing $\$ 19$ & 152 & 169 & 4 & 4 & 22 & 16 & 140 & 212 & 62 & 84 & 137 & 97 & 562 & 715 \\
\hline Whitewing $\$ 20$ & 152 & 142 & 4 & 2 & 18 & 8 & 132 & 111 & 70 & 100 & 147 & 110 & 554 & 557 \\
\hline Whitexing is 22 & 252 & 150 & 4 & 2 & 21 & 10 & 228 & 134 & 64 & 91 & 147 & 113 & 550 & 573 \\
\hline
\end{tabular}


Peterson (1968) conducted a gravity survey of the Hyder area, and the U.S. Geological Survey is now conducting a gravity survey just south of the area. Map IV-4 shows the residual aeromagnetic data of the area; contour intervals are 25 gammas. Magnetic highs are prominent in the Little Horn Mountains at the northwest end of the area and in the northern end of the Gila Bend Mountains, 30 kilometers north of Hyder. In a general way, the gravity contour lines follow the axial trends of the mountains. Magnetic intensity also tends to decrease from north to south across the study area. Two small gravity lows are within the area, one in the central portion of the Palomas Plain and the other on the northeastern side of the Tank Mountains. A 300 gamma magnetic low occurs just south of the Palomas Mountains.

The residual Bouguer gravity map (Map IV-5) is contoured on 5 mgal intervals. The major gravity low is located north of Baragan Mountain in the Palomas Plain, and a small gravity low occurs about 5 kilometers south of the Horn.

A seismic profile across the smaller gravity low was constructed by Exxon geologists (Eberly and Stanley, 1978). Figure IV-1 shows the results of that survey as well as locating two oil and gas test holes. The basin thickness from these tests is estimated at 2,700 meters. True graben structures were encountered in the seismic survey and are indicated in Figure IV-l. The Palomas Plain gravity low should indicate 3,000 meters or more of Cenozoic material, but bedrock outcrop 
within the low may substantially reduce this estimate. Density contrasts between bedrock and basin material would best explain the differences between the two gravity anomalies.

5. Water Temperatures and Gradients. Most of the wells completed in the Hyder area are used for irrigation of cotton, grapes, wheat and citrus crops. Approximately 250 wells were reviewed, edther in person or through a 11 terature search. The majority of these wells were completed to a depth of less than 100 meters. Table IV-4 lists 88 sites where natural waters have temperatures greater than $30^{\circ} \mathrm{C}$. Ten of the wells have temperatures of $40^{\circ} \mathrm{C}$ or greater. All known discharge temperatures are shown on Map IV-6.

Simple temperature gradients were calculated by subtracting the mean annual air temperature from the water temperature, then dividing the result by the reported depth of the well. A mean annual air temperature of $22.40 \mathrm{C}$ was selected from Druitt's (1976) map. The metric system was used throughout and the results were recorded in ${ }^{\circ} \mathrm{C} / \mathrm{km}$. Only those wells whose depths were in excess of $100 \mathrm{~m}$ were used so as to eliminate gradients that might be influenced by near-surface thermal phenomena or ground-water recharge. Results were grouped as to gradient range and plotted on Map IV-7. These values should be viewed as minimum temperature gradients as they assume 100 percent of the water coming from the deepest penetration of the well. No provisions were made for mixing of waters from different aquifers or for depth at which the pumps were set. 
Table IV-4. Wells and Springs in the Hyder Area with Temperatures of $30^{\circ} \mathrm{C}$ or Greater

\begin{tabular}{|c|c|c|c|c|}
\hline Location & $\begin{array}{c}\text { Temperature } \\
{ }^{\circ} \mathrm{C} \\
\end{array}$ & $\begin{array}{l}\text { Depth } \\
\text { Meters }\end{array}$ & $\begin{array}{c}\text { Map } \\
\text { Quadrangle }\end{array}$ & Reference \\
\hline$(c-3-11) 25 c b$ & 48.9 & 401 & Hyder & 1 \\
\hline$(c-4-7) 34 c d c$ & 31.0 & 253 & Dendora Valley & 1,3 \\
\hline$(C-4-8) 26$ add & 32.8 & 56 & Dendora Valley & 2,3 \\
\hline$(c-4-8) 26 d d d$ & 34.5 & 59 & Dendora Valley & 2,3 \\
\hline$(c-4-8) 35 b d d$ & 30.6 & 83 & Dendora Valley & 2,3 \\
\hline$(C-4-8) 35$ daa & 30.6 & 65 & Dendora Valley & 2 \\
\hline$(c-4-8) 35 \mathrm{dbb}$ & 30.3 & 68 & Dendora Valley & 2 \\
\hline$(c-4-10) 3 d a a$ & 33.5 & 137 & Hyder & $1,2,3$ \\
\hline$(c-4-10) 5 a b b$ & 36.0 & 389 & Hyder & 3 \\
\hline$(c-4-10) 5 b b b$ & 34.0 & 300 & Hyder & 4 \\
\hline$(c-4-10) 6 b b$ & 36.7 & 305 & Hyder & 1 \\
\hline$(c-4-10) 7 b b$ & 35.0 & 196 & Hyder & 1 \\
\hline$(c-4-10) 16 a b b$ & 31.5 & - & Hyder & 4 \\
\hline$(c-4-10) 16 b b b$ & 32.5 & - & Hyder & 4 \\
\hline$(C-4-10) 17 \mathrm{da} a$ & 31.0 & - & Hyder & 4 \\
\hline$(c-4-10) 17 \mathrm{dbb}$ & 30.0 & - & Hyder & 4 \\
\hline$(c-4-11)$ laaa & 32.8 & 102 & Hyder & 5 \\
\hline$(c-4-11) 2 b b b$ & 39.5 & 162 & Hyder & $1,3,6,7$ \\
\hline$(c-4-11) 2 b c b$ & 37.8 & 162 & Hyder & 1 \\
\hline$(C-4-11) 5 b b b$ & 40.5 & 142 & Baragon Mountains & $2,3,7$ \\
\hline$(c-4-11) 6 a a b$ & 37.8 & 143 & Baragon Mountains & 2,3 \\
\hline$(c-4-11) 8 b b b$ & 40.0 & 200 & Baragon Mountains & 3,4 \\
\hline
\end{tabular}




\begin{tabular}{|c|c|c|c|c|}
\hline location & $\begin{array}{c}\text { Temperature } \\
{ }^{\circ} \mathrm{C} \\
\end{array}$ & $\begin{array}{l}\text { Depth } \\
\text { Meters }\end{array}$ & $\begin{array}{c}\text { Map } \\
\text { Quadrang10 }\end{array}$ & Reference \\
\hline$(C-4-11) 11 a b a$ & 37.8 & 184 & Hyder & 1 \\
\hline$(C-4-11) 11 b a b$ & 37.2 & 168 & Hyder & 1,7 \\
\hline$(c-4-11) 12 a b b$ & 38.0 & 375 & Hyder & 1,7 \\
\hline$(c-4-11) 12 b b b$ & 35.0 & 126 & Hyder & 2,3 \\
\hline$(c-4-11) 16 b b b$ & 30.0 & 153 & Baragon Mountalns & $1,3.7$ \\
\hline$(c-4-11) 21 a b b$ & 32.2 & 419 & Baragon Mountains & 1,3 \\
\hline$(c-4-11) 21 b b b$ & 30.5 & 397 & Baragon Mountains & 3 \\
\hline$(c-4-11) 33 b b b$ & 30.0 & 332 & Baragon Mountalns & 4,7 \\
\hline$(C-5-7)$ laaa & 31.0 & 214 & Vulture Mountalns & 1,3 \\
\hline$(c-5-9) 12 a c d$ & 32.8 & 189 & Agu1la Mountains & 2,3 \\
\hline$(c-5-10) 16 b b b$ & 45.6 & 387 & Agua Caliente Mts. & 1 \\
\hline$(c-5-10) 16 b b c$ & 45.8 & - & Agua Callente Mits. & 6 \\
\hline$(c-5-10) 16 \mathrm{cbb}$ & 32.8 & 22 & Agua Caliente Mts. & 2,3 \\
\hline$(c-5-10) 16 \mathrm{cbc}$ & 40.0 & 110 & Agua Callente Mts. & 3,7 \\
\hline$(\mathrm{C}-5-10) 16 \mathrm{ccb}$ & 39.4 & 26 & Agua Caliente Mts. & 2,3 \\
\hline$(c-5-10) 18 c d a$ & 34.5 & - & Agua Callente Mts. & 3 \\
\hline$(c-5-10) 19 a a$ & $35-40$ & Springs & Agua Caliente Mts. & 2 \\
\hline$(C-5-10) 20 d b d$ & 33.3 & 4 & Agua Caliente Mts. & 2,3 \\
\hline$(c-5-10) 28 \mathrm{dcb}$ & 39.0 & 396 & Agua Caliente Mts. & 3,7 \\
\hline$(c-5-11) 1 d c$ & 31.7 & 275 & Agua Caliente Mts. & 1,7 \\
\hline$(c-5-11) 2 b b b$ & 39.0 & 305 & Agua Caliente Mts. & 2,3 \\
\hline$(C-5-11) 4 a b$ & 30.0 & 111 & Baragon Mountains & 1 \\
\hline$(c-5-11) 11 c a b$ & 36.7 & 214 & Agua Callente Mts. & 1,3 \\
\hline$(\mathrm{C}-5-11) 12 \mathrm{cba}$ & 31.1 & 30 & Agua Caliente Mts. & 2 \\
\hline$(c-5-11) 15 a b b$ & 35.5 & 244 & Aztec NW & 2,3 \\
\hline
\end{tabular}


Location

(C-5-12) 3aa

$(c-5-12) 4 b c b$

(C-5-12) 4bcc

(C-5-12) 4cbc

$(c-5-12) 4 c d b$

(c-5-12) 4cdd

(C-5-12) 5aaa

(C-5-12) 5aab

(C-5-12) 5aad

$(C-5-12) 5 a b b$

$(c-5-12) 9 a b c$

(C-5-12)9acc

(C-5-15) $9 \mathrm{bbb}$

$(\mathrm{C}-5-12) 9 \mathrm{cba}$

$(c-5-12) 9 c b c$

$(C-5-12) 9 c c a$

$(C-5-12) 15 b c b$

(C-5-12) 15cbd

(C-5-12) 15cca

(C-5-12) 16aab

(C-5-12) 16aa

(C-5-12)16abb

$(\mathrm{c}-5-12)_{16 \mathrm{abb}_{2}}$

(C-5-12) 16aba

(C-5-12)16acc
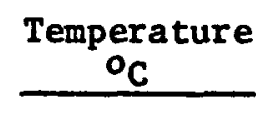

32.2

30.2

32.0

30.0

35.0

34.0

31.1

30.5

30.5

32.0

38.8

41.6

32.0

42.5

42.5

40.0

33.3

34.0

34.2

32.8

32.2

36.7

32.0

37.8

33.3
Depth

Meters

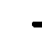

113

152

95

602

518

218

43

90

542

500

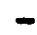

171

503

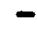

489

154

145

145

27

191

203

122

196

282
Map

Quadrangle

Baragon Mountains

Baragon Mountains

Baragon Mountalns

Baragon Mountalns

Baragon Mountains

Baragon Mountalns

Salome

Salome

Salome

Salome

Baragon Mountains

Baragon Mountains

Baragcn Mountains

Baragon Mountains

Baragon Mountains

Baragon Mountalns

Aztec NW

Aztec NW

Aztec NW

Aztec NW

Aztec NW

Aztec NW

Aztec NW

Aztec

Aztec
3,4

3

$\underline{\text { Reference }}$

6

$2,3,6$

4

$1,3,4$

4

4,7

2

1

4

4

6

6

4

4

2

1,3

1

$1,3,7$

1

4

$1,4,7$

1,7

2 


\begin{tabular}{|c|c|c|c|c|}
\hline Location & $\begin{array}{c}\text { Temperature } \\
\mathrm{O}^{\circ} \mathrm{C} \\
\end{array}$ & $\begin{array}{l}\text { Depth } \\
\text { Meters }\end{array}$ & $\begin{array}{c}\text { Map } \\
\text { Quadrangle }\end{array}$ & Reference \\
\hline$(c-5-12) 16 a d$ & 33,3 & 154 & Aztec & 1,7 \\
\hline$(C-5-12) 16 b a$ & 35.0 & 226 & Aztec & 1,7 \\
\hline$(\mathrm{C}-5-12) 16 \mathrm{baa}$ & 35.0 & 245 & Aztec & 2,4 \\
\hline$(c-5-12) 16 b b b$ & 35.0 & 139 & Aztec & $2,4,7$ \\
\hline$(C-5-12) 21 a a d$ & 33.9 & 177 & Aztec & 1,7 \\
\hline$(c-5-12) 21 b b$ & 32.8 & 114 & Aztec & 1,7 \\
\hline$(C-5-12) 21 b b b$ & 33.9 & 136 & Aztec & 2,3 \\
\hline$(c-5-12) 21 \mathrm{bbd}$ & 33.3 & 79 & Aztec & 2,3 \\
\hline$(c-5-12) 22 b b c$ & 34.4 & 174 & Azten & 2 \\
\hline$(c-5-12) 28 a a a$ & 33.3 & 218 & Aztec & 2 \\
\hline$(c-5-12) 33 c d a$ & 31.1 & 75 & Aztec & $1,3,7$ \\
\hline$(c-5-12) 35 b b b$ & 30.8 & 148 & Aztec & 2.3 \\
\hline$(c-6-7) 1$ bdd & 30.0 & - & Theba & 3 \\
\hline$(c-6-7) 11 a b c$ & 31.0 & 375 & Theba & 3 \\
\hline$(c-6-7) 11 d c c$ & 31.0 & 282 & Theba & 3 \\
\hline$(c-6-7) 12 \mathrm{ccc}$ & 33.0 & 423 & Theba & 3 \\
\hline
\end{tabular}

Ref erences:

1. Giardina and Conley, 1978

2. Armstrong and Yost, 1958

3. U.S. Geological Survey, 1979

4. This report

5. Arizona Land Department, Open File

6. Swanberg and others, 1977

7. Welst, 1965 
There are 73 wells within the Hyder area with recorded temperatures and whose depths exceed 100 meters. An additional 28 wells have been recorded with temperatures, in the literature, yet have been completed to depths less than 100 meters. Table IV-5 1 ists the arithmetic mean and weighted mean temperature gradients for wells less than 100 meters in depth, as well as those in the intervals of 100-200 meters, 200-400 meters, and in excess of 400 meters. The increase in depth reduces the magnitude of the average simple temperature gradient. This reduction is in response to the normal thermal behavior within the region as depicted in Figure IV-2.

The weighted mean temperature gradients as well as the ranges for each of the depth intervals are also depicted in Figure IV-2. Pumping records of those wells in excess of 400 meters indicate long and constant usage. The one exception is the Exxon oil test well in T.3S., R.11W., Sec. 25cb. Its total depth is 401 meters, bottom hole temperature $48.9^{\circ} \mathrm{C}$, and the simple temperature gradient is $66.1^{\circ} \mathrm{C} / \mathrm{km}$. The geophysical logs for this hole were examined in the offices of the Arizona Oil and Gas Conservation Commission, Phoenix. The temperature increases with each successive measurement. Temperature equilibration had not been achieved by the end of the test.

Extensive water well sampling at the Whitewing Ranch was undertaken in April, 1979. The Na-K-Ca chemical geothermometer of Fournier and Truesdall (1973) was applied to these samples, 
c

C

峞

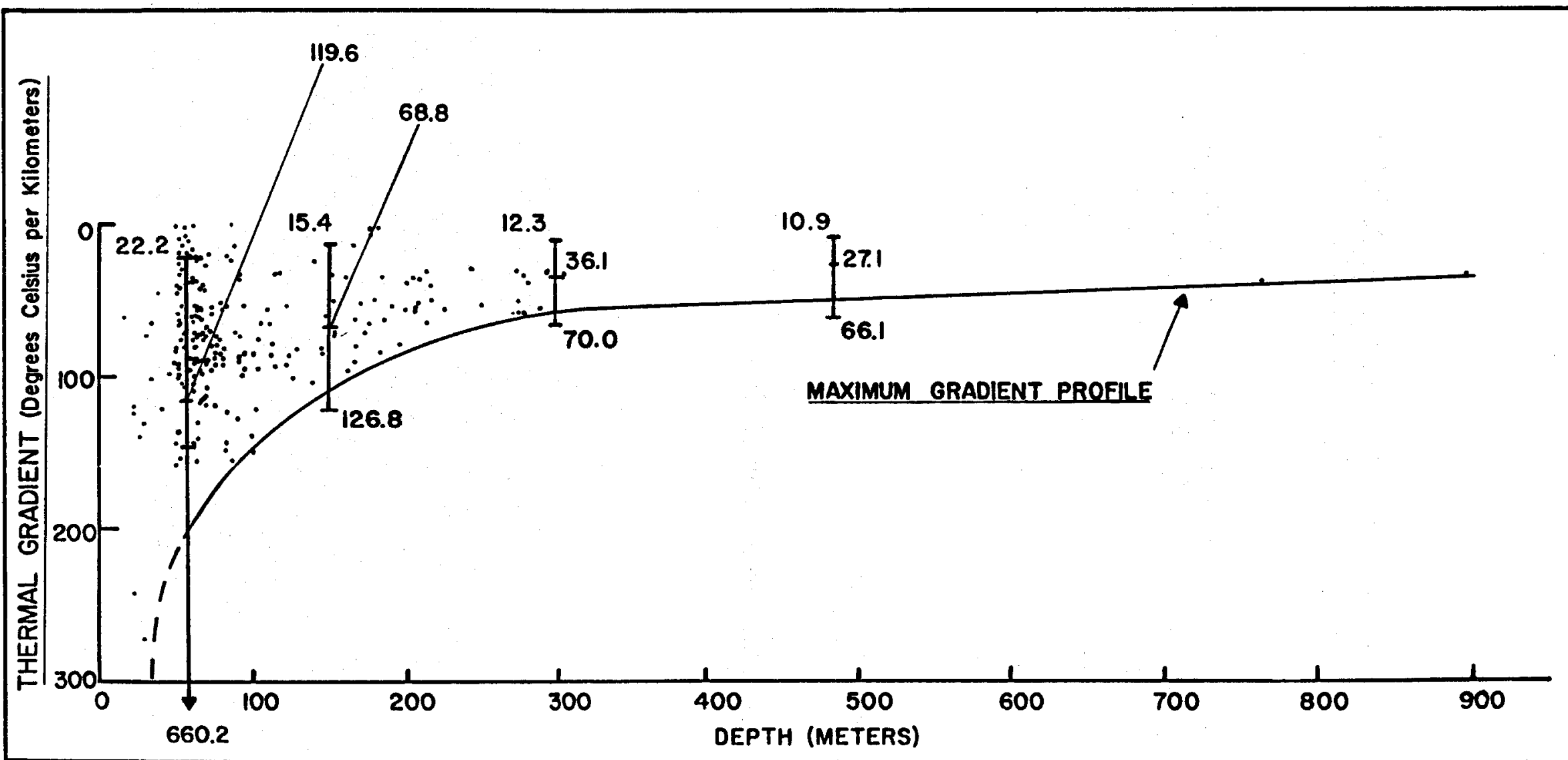

FIGURE IV-2. MAXIMUM GRADIENT PROFILE OF YO MA COUNTY WITH GRADIENT RANGES FOR THE HYDER AREA (AFTER GIARDINA AND CONLEY, 1978). 


\section{Table IV-5. Temperature Gradients for Wells \\ In the Hyder Area}

\begin{tabular}{|c|c|c|c|c|}
\hline $\begin{array}{l}\text { Interval } \\
\text { (Meters) }\end{array}$ & $\begin{array}{c}\text { Number of } \\
\text { We11s } \\
\end{array}$ & $\begin{array}{c}\text { Average Depth } \\
\text { (Meters) } \\
\end{array}$ & $\begin{array}{l}\text { Artthmet1c Mean* } \\
\text { Gradient }\left({ }^{\circ} \mathrm{C} / \mathrm{km}\right)\end{array}$ & $\begin{array}{l}\text { Weighted Mean** } \\
\text { Gradient }\left({ }^{\circ} \mathrm{C} / \mathrm{km}\right)\end{array}$ \\
\hline $0-100$ & 28 & 57.9 & 149.7 & 119.6 \\
\hline $100-200$ & 37 & 150.6 & 69.7 & 68.8 \\
\hline $200-400$ & 26 & 293.0 & 37.4 & 36.1 \\
\hline$>400$ & 10 & 482.2 & 27.9 & 27.1 \\
\hline
\end{tabular}

* \& (Temperature Gradient) Number of Wells

** $\sum$ (Temperature Gradient $x$ Depth of Well)

Depth of Well 
R. 12 W.

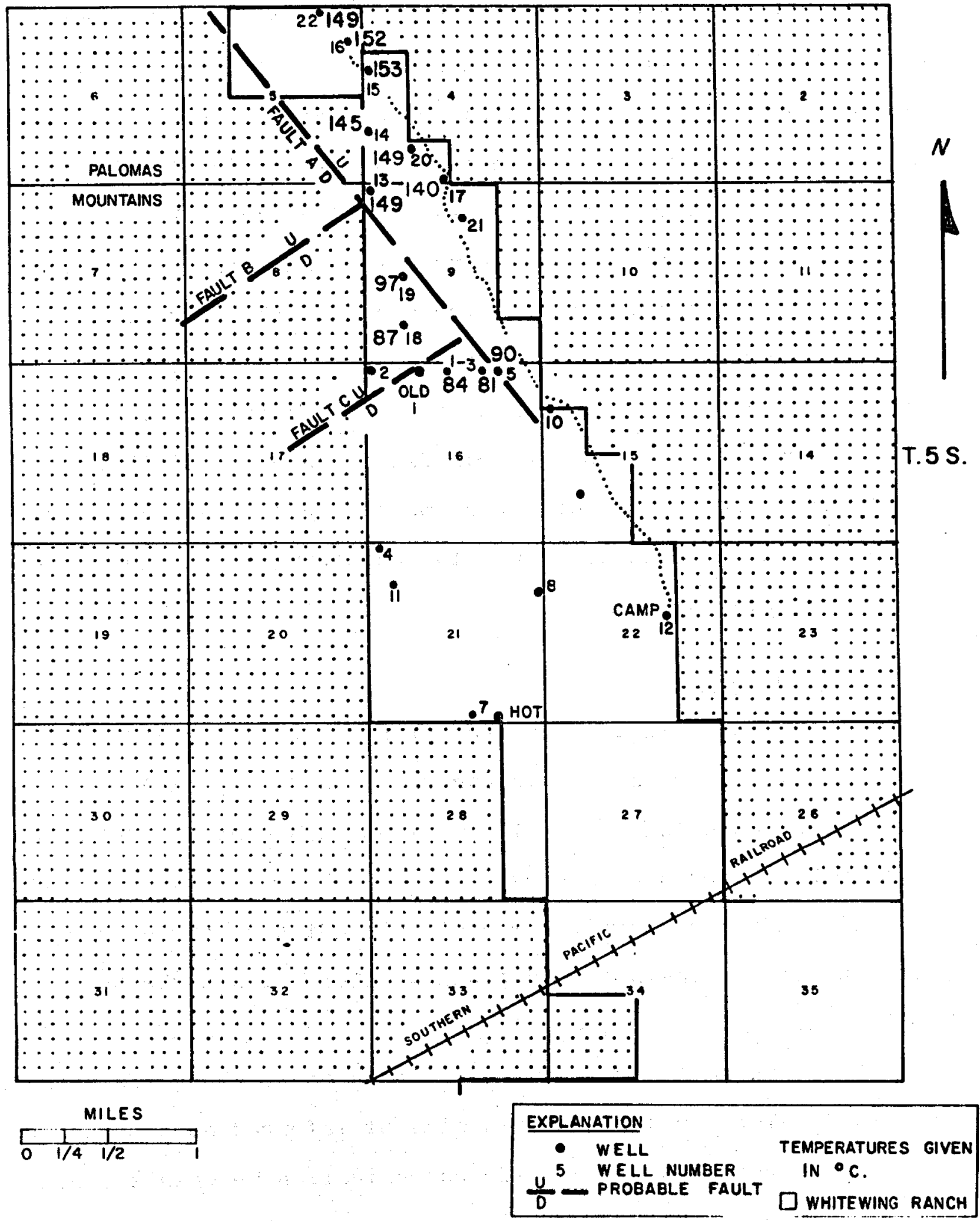

FIGURE IV-3. PROBABLE FAULTS ACROSS THE WHITEWING RANCH AND THE NO-K-Co CHEMICAL GEOTHERMOMETERS. (AFTER MANERA, 1977). 
and the results were plotted on the "Probable Fault Map" of Manera (1977). Figure IV-3 is Manera's map with the Na-K-Ca values added. The higher indicated temperatures $\left(>100^{\circ} \mathrm{C}\right)$ are all east of the proposed northwest fault which fronts the eastern side of the Palomas Mountains. One must, therefore, conclude that there is a real structure separating the higher values from the lower temperatures and that this structure may provide through-going communication between a heat source and the shallow aquifers. A graben structure is inferred.

Elsewhere within the Palomas plain there are similar geochemical indications of one or more deep heat sources. None is as well documented as around the Whitewing Ranch due to the lack of close-spaced wells.

D. Conclusions

1. Eighty-eight wells and springs within the Hyder area have reported temperatures in excess of $30^{\circ} \mathrm{C}$. A complete inventory of the more than 250 wells will no doubt reveal additional warm or hot water occurrences.

2. Assuming normal temperature gradients, the deeper portions of the basin should contain waters within the 50 to $150^{\circ} \mathrm{C}$ range.

3. Abnormal temperature gradients occur along the margains of gravity lows or on the basin-side of inferred deep structures. The deep structures may provide communication between the heat source or sources and the aquifers which display the higher temperature gradients. 
4. Areas of geothermal interest are: 1) the inferred deep portion of the basin north of Baragan Mountain, 2) the area just south of Horn, 3) the area south of Turtleback Mountain and Agua Caliente Mountain.

5. Additional studies of the existing water wells may help to further delineate the size and thermal properties of this geothermal resource area. Several seismic profiles similar to those run by the Exxon Corporation may reveal deep graben structures in the aforementioned areas of interest. 
V. HYDER VALLEY RESERVOIR ESTIMATE

The Hyder valley-Palomas plain area has been divided into four parts for purposes of the reservoir estimate. These four parts are the Horn area, the Agua Caliente area, the Palomas plain, and about $657 \mathrm{~km}^{2}$ of alluvial areas outside of the other three, more favorable areas. The water in the upper part of the groundwater basin is extensively used for municipal and agricultural supply, therefore, the upper $300 \mathrm{~m}$ of the groundwater basin has been excluded from the reservoir estimate.

Based on the description of Basin and Range structure and stratigraphy by Eberly and Stanley (1978), and the gravity map of Aiken (1975), this area is probably underlain by about $300 \mathrm{~m}$ of extrusive volcanic rocks under a cover of continental deposits ranging from 0 to $600 \mathrm{~m}$ in thickness, but averaging about $300 \mathrm{~m}$. In the Horn area, the volcanics are absent and the younger continental sediments rest directly on about $1400 \mathrm{~m}$ of older, deformed continental sediments. These units rest on a basement complex composed of pre-Tertiary igneous and metamorphic rocks. Porosity and specific yield of the materials comprising the groundwater reservoir have been estimated using reasonable values for these rock types.

The total volume of water in storage in the groundwater reservoir below $300 \mathrm{~m}$ amounts to $60,600 \mathrm{hm}^{3}$. Recoverable water amounts to about $23,500 \mathrm{hm}^{3}$. Table $\mathrm{V}-1$ summarizes the reservoir estimate.

Groundwater in this area may occur under unconfined, semi- 
confined or confined conditions locally. Except in the Horn area, subsidence is not expected to be a problem. In the shallow parts of the groundwater basin, high salinity is not expected to be a problem. Geotechnical problems such as subsidence or high salinity might be encountered if water is mined from deep parts of the sedimentary section beneath the Horn area, but the extent of these problems cannot be estimated from the available data. 
Table V-1. Hyder Valley - Palomas Plain

Sediment Type

Horn Area

continental seds.

older cont. seds.

Agua Caliente Area

continental seds.

volcanic rocks

Palomas Plain

continental seds.

volcantc rocks

A11 Other Areas

continental seds. volcanic rocks
Thickness

$1200 \mathrm{~m}$

$1400 \mathrm{~m}$

$0-150 \mathrm{~m}$

$200 \mathrm{~m}$

$600 \mathrm{~m}$

$300 \mathrm{~m}$

$0-150 \mathrm{~m}$
$150 \mathrm{~m}$
Area

$122 \mathrm{~km}^{2}$

$122 \mathrm{~km}^{2}$

$228 \mathrm{~km}^{2}$

$228 \mathrm{~km}^{2}$

$5 \%$

$1 \%$

Porosity Specific Yield

$20 \%$

$10 \%$

$10 \%$

$3 \%$

$10 \%$

$10 \%$

$1 \%$

$168 \mathrm{~km}^{2}$

$5 \%$

Water in Storage

Continental Seds.

$32,600 \mathrm{hm}^{3}$

$11,000 \mathrm{hm}^{3}$

$17,000 \mathrm{hm}^{3}$
$20 \%$

$5 \%$
$10 \%$

$1 \%$
Volcanic Rocks

Older Continenetal Seds.
Recoverable Water

$15,200 \mathrm{hm}^{3}$

$2,200 \mathrm{hm}^{3}$

$5,100 \mathrm{hm}^{3}$ 
VI. ENVIRONMENTAL ASPECTS

\section{A. General}

So far the investigation of the Hyder area has not disturbed the environment. Field work involved location and sampling of existing water wells, irrigation wells, seeps and springs.

Should additional work in the area be required, it probably would not involve surface disturbance. Additional wells, especially the deeper ones, would have to be sampled. Geophysical techniques, such as close-spaced gravity determinations, may be needed to better define the extent of the basin. No surface disturbance is involved in such a survey.

If heat flow drilling is deemed necessary, the judicious selection of drill site or sites will minimize local impact. Since the area is currently being farmed, there is the likelihood of one or more drill sites being located in or adjacent to farm land. The impact on the natural or farm environment would be minimal and of short duration.

Should an economic resource area or areas be delineated within the Hyder area, appropriate care and concern will be taken to extract the geothermal heat and water. The problems associated with the development of geothermal resources within a heavily farmed area should be akin to those of developing new irrigation wells which do not contain the thermal energies. Brine and/or salt may be a by-product of the upgraded waters. Disposal or sale of these by-products will depend upon their 
composition and quantity. Speculation on removal of these products from the surface environment will have to be deferred until such time as the chemical composition of the resource water is known.

Withdrawal of ground waters may also cause local subsidence. This is true whether the waters are thermal or not. In this respect, the development of the resource for its water content is no different than if one were to develop shallow irrigation wells of equal capacity. The main difference between the geothermal waters and the currently exploited irrigation waters (other than their thermal characteristics) is that the geothermal waters are deeper. 


\section{BIBLIOGRAPHY}

Aiken, C.L.V., 1975, Residual Bouguer gravity anomaly map of Arizona: Tucson, Department of Geosciences, University of Arizona, 1 sheet.

Armstrong, C.A., and Yost, C.B., Jr., 1978, Geology and groundwater resources of the Palomas Plain-Dendora Valley area, Maricopa and Yuma Counties, Arizona: Arizona State Land Department Water-Resources Report 4, $49 \mathrm{p}$.

Babcock, H.M., Brown, S.C., and Hem, J.D., 1947, Geology and ground-water resources of the Wellton-Mohawk area, Yuma County Arizona: U.S. Geological Survey Open-File Report, 22 p.

Babcock, H.M., and Dendall, K.K., 1948, Geology and groundwater resources of the Gila Bend basin, Maricopa County, Arizona, with a section on water quality, by J.D. Hem: U.S. Geological Survey Open-File Report, 26 p.

Bryan, K., 1925, The Papago Country, Arizona: a geographic, geologic, and hydrologic reconnaissance with a guide to desert watering places: U.S. Geological Survey WaterSupply Paper 499, 436 p.

Cahill, J.M., and Wolcott, H.N., 1955, Further investigations of the ground-water resources of the Gila Bend and Dendora areas, Maricopa County, Arizona: U.S. Geological Survey Open-File Report, 14 p.

Druitt, C.E., 1976, Mean annual temperature map, State of Arizona: Arizona $O i 1$ and Gas Conservation Commission Map GT-2.

Eberly, L.D., and Stanley, T.B., Jr., 1978, Cenozolc stratigraphy and geologic history of southwestern Arizona:

Geologic Soclety of America Bulletin, Vol. 89, p. 921-940.

Halpenny, L.C., and others, 1952, Ground-water in the Gila River basin and adjacent areas, Arizona, a summary: U.S. Geological Survey Open-File Report, 224 p.

Fournier, R.O., and Truesdell, A.H., 1973, An empirical Na-K-Ca geothermometer for natural waters: Geochem et Cosmochim Acta, Vol. 37, p. 1255-1275.

Giardina, S., Jr., and Conley, J.N., 1978, Thermal gradient anomalies: Arizona Oil and Gas Conservation Commission Report No. 6, 49 p. 
Ibrahim, M.S., 1962, Subsurface geology and chemical quality of ground-water in the Buckeye Valley, Arizona: University of Arizona M.S. Thesis, $97 \mathrm{p}$.

Johnson, P.W., and Cahill, J.M., 1954, Ground-water resources and geology of the Gila Bend and Dendora areas, Maricopa County, Arizona: U.S. Geological Survey Open-File report, $53 \mathrm{p}$.

Manera, P.A., 1977, Groundwater resources and projected water levels, 1976-1981, Whitewing Ranch, Yuma County: Con Consulting Report for Whitewing Agriculture, Inc., 7 p. (Maps, Appendix).

Miller, F.K., and McKee, E.H., 1971, Thrust and strike-slip faulting in the Pomosa Mountains, southwestern Arizona: Geological Society of America Bulletin, Vol. 82, p. 717722 .

Peterson, D.L., 1968, Bouguer gravity map of parts of Maricopa, Pima, Pinal, and Yuma Counties, Arizona: U.S. Geological Sruvey Geophysical Inv. Map GP-615.

Ross, C.P., 1922, Geology of the lower Gila region, Arizona: U.S. Geological Survey Prof. Paper 129.H, p. 183-197.

Ross, C.P., 1923, The lower Gila region, Arizona: a geographic, geologic, and hydrologic reconnaissance with a guide to desert watering places: U.S. Geological Survey WaterSupply Paper 498, 237 p.

Sauck, W.A., and Sumner, J.S., 1970, Residual aeromagnetic map of Arizona: Tucson, University of Arizona Press.

Shoustra, J.J., Smith, J.L., Scott, J.D., Strand, R.L., and Duff, D., 1976, Geology and seismicity, site lithologic conditions and Appendix ZQ (radiometric age dating): in Palo Verde Nuclear Generating Station 1,2, and 3, Preliminary Safety analysis Report: Arizona Public Service Commission, Vol. 2, p. 2.5-60 to 2.5-76, and Vol. 8, Appendix ZQ.

Smith, H.V., and others, 1963, The quality of Arizona's domestic waters. University of Arizona, Agricultural Experiment Station Report 217, $77 \mathrm{p}$.

Swanberg, C.A., Morgan, P., Stoyer, C.H., and Witcher, J.C., 1977, An appraisal study of the geothermal resources of Arizona and adjacent areas in New Mexico and Utah and their value for desalination and other uses: New Mexico Energy Institute Report 6, $75 \mathrm{p}$. 
United States Geological Survey, 1979, WATSTORE (computer tape).

Weist, W.G., Jr., 1965, Geohydrology of the Dateland-Hyder area, Maricopa and Yuma Counties, Arizona: Arizona State Land Department Water Resources Report 23, 46 p.

Wilson, E.D., 1933, Geology and mineral deposits of southern Yuma County, Arizona: Arizona Bureau of Mines Bulletin 137,236 p. 


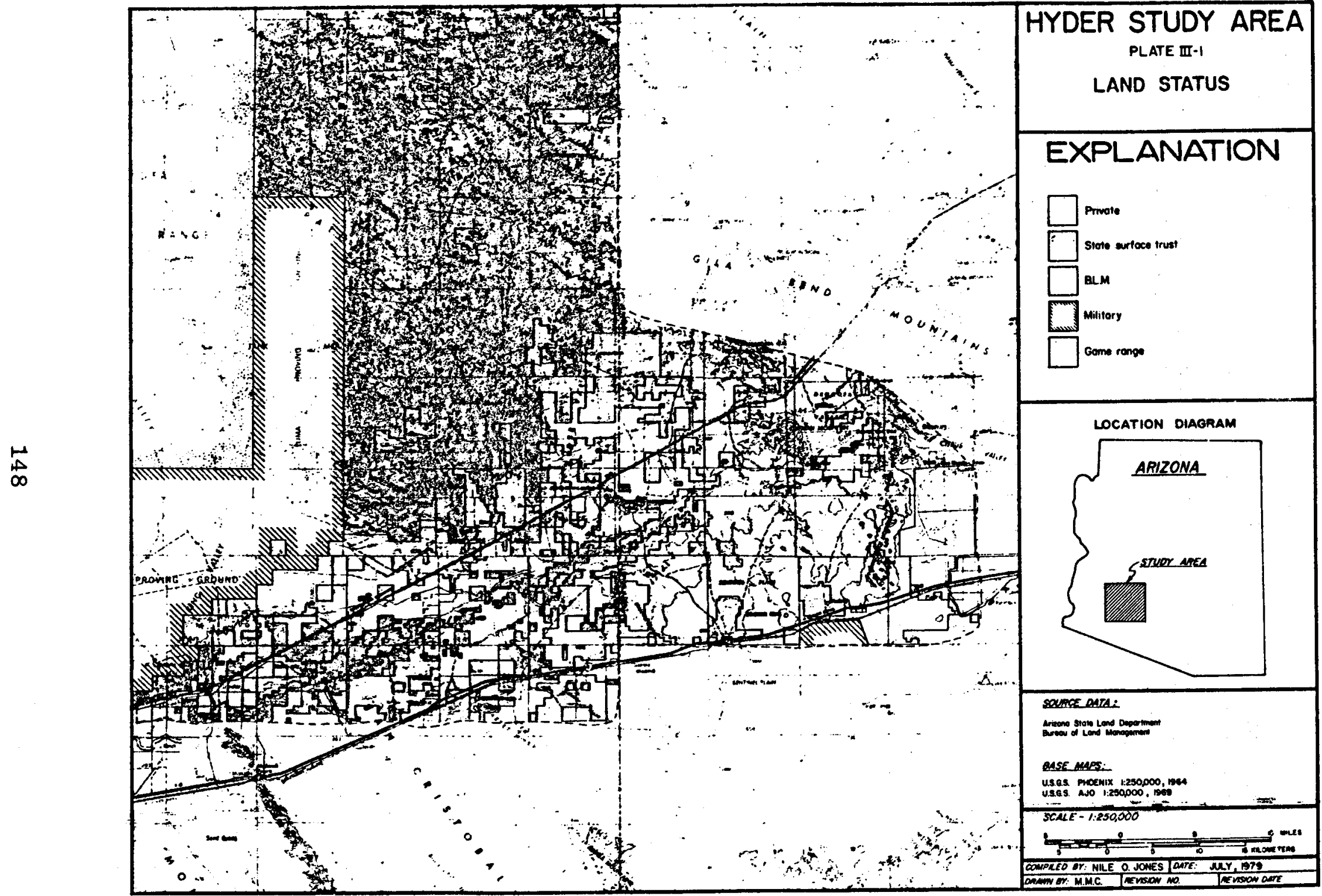




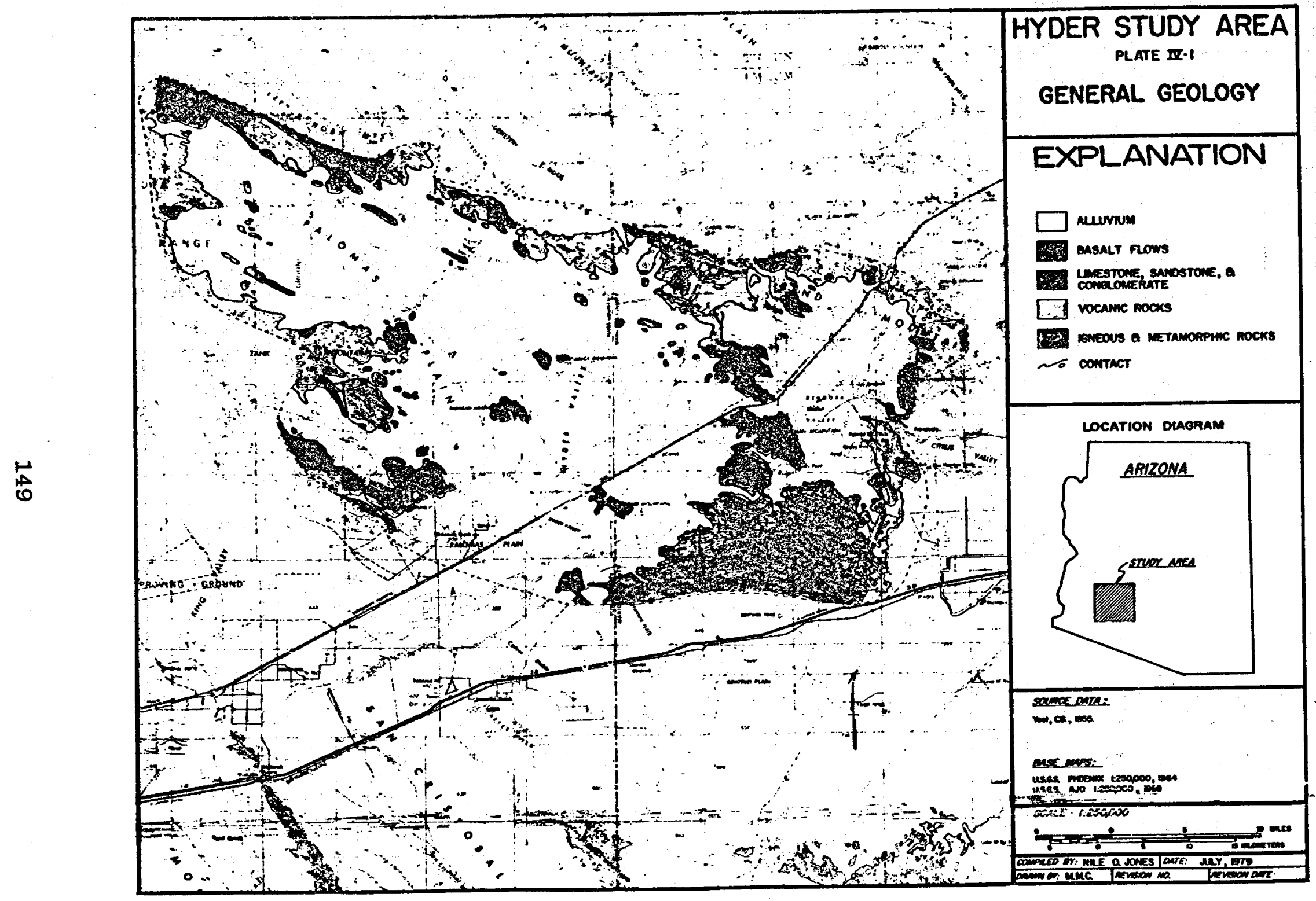




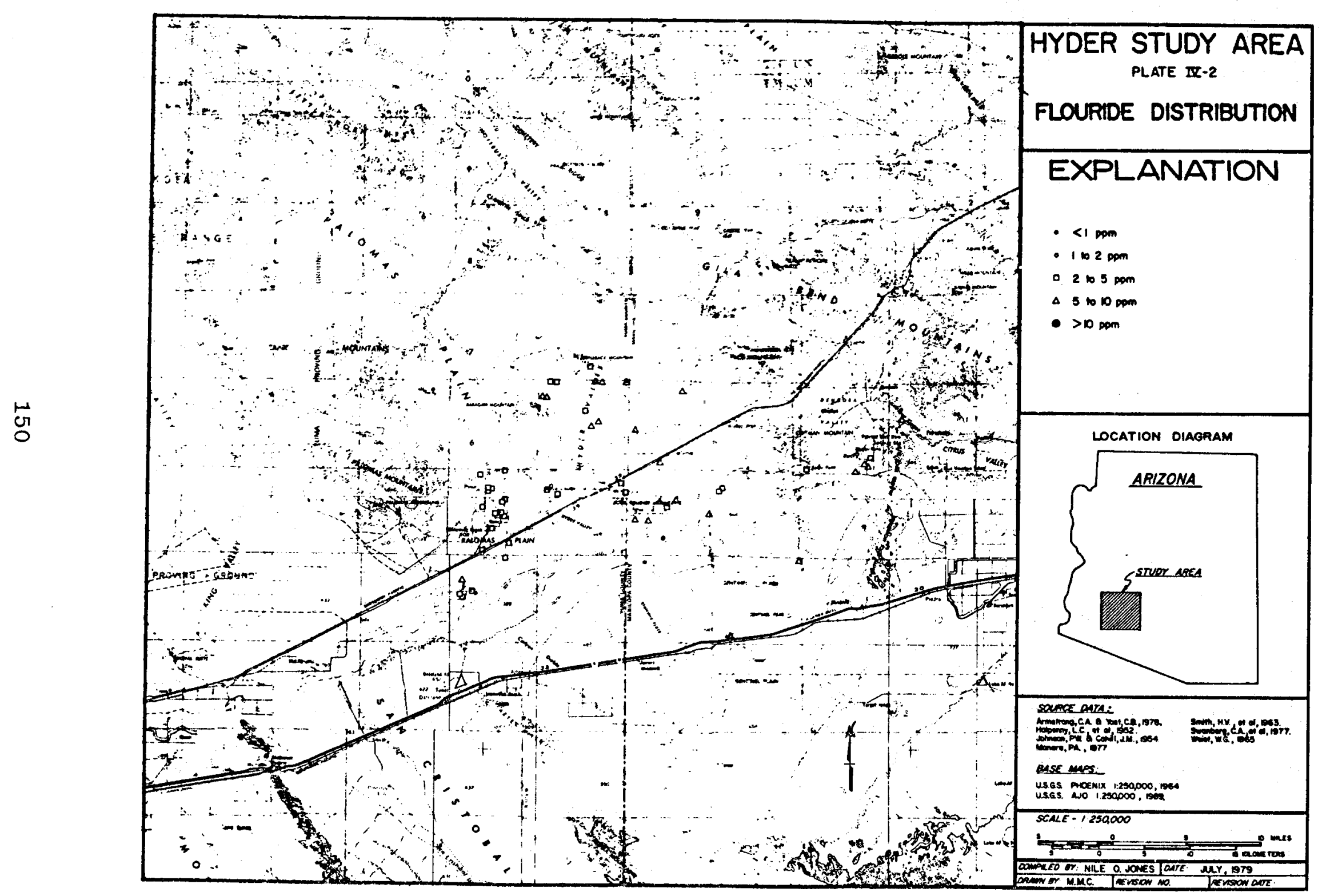




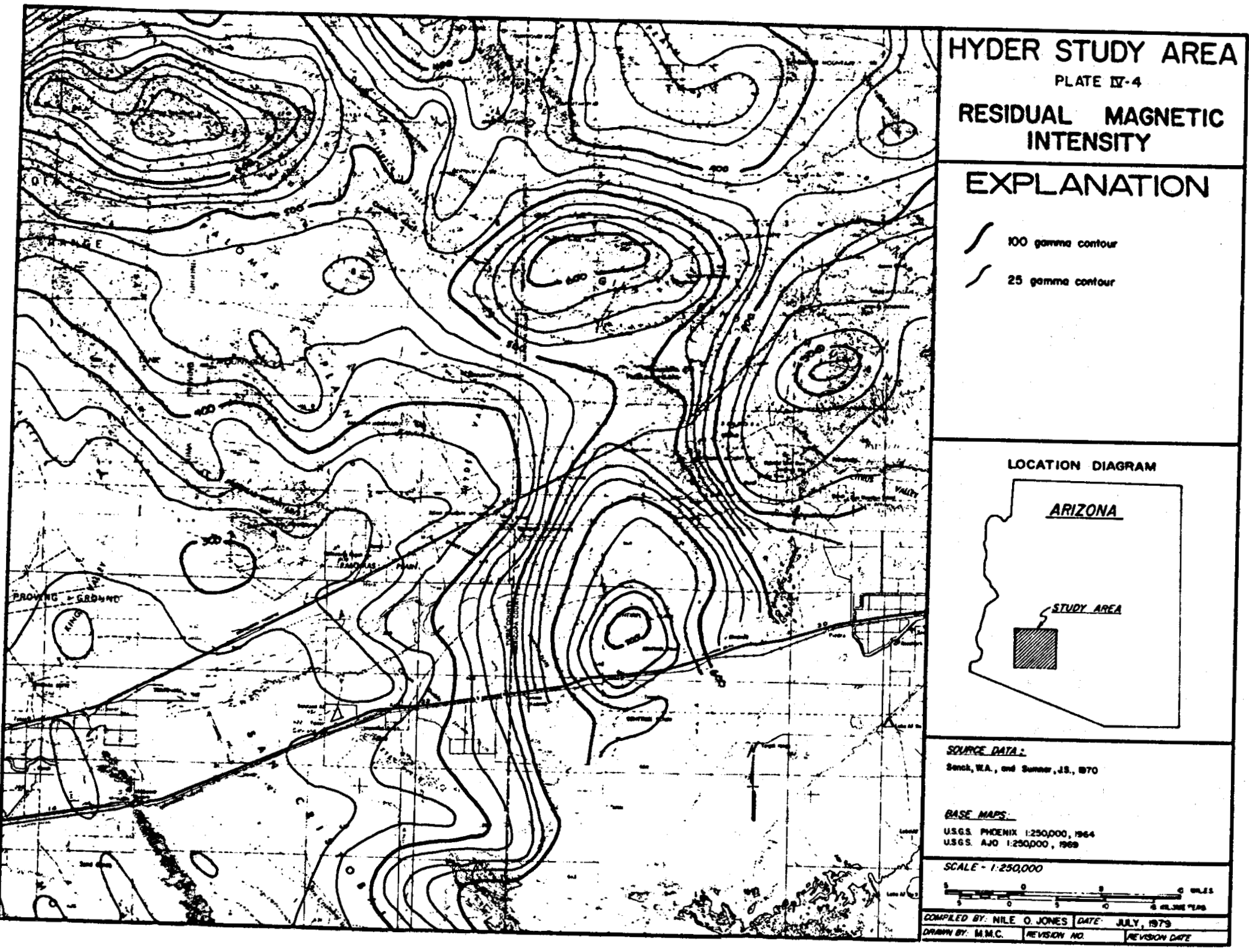




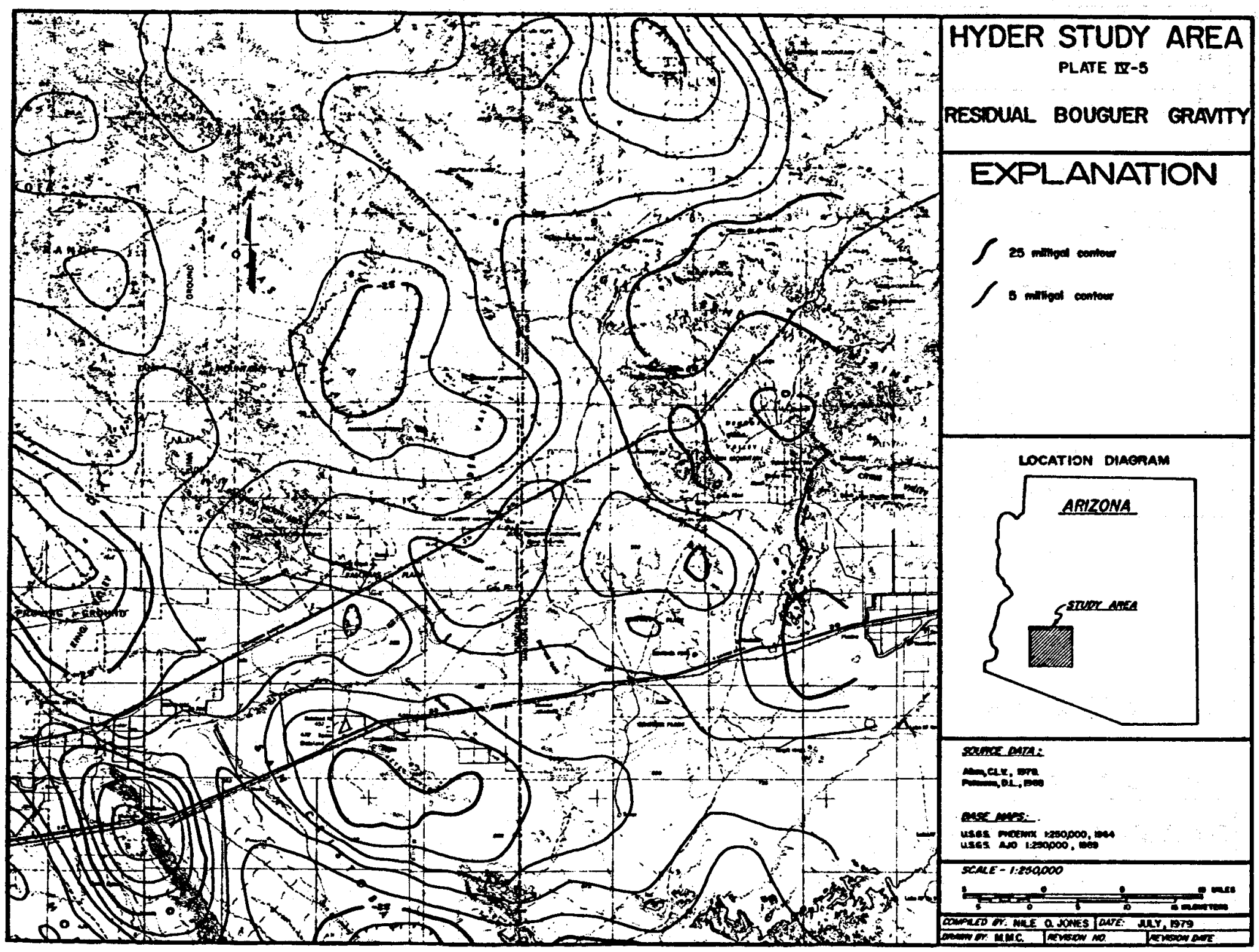




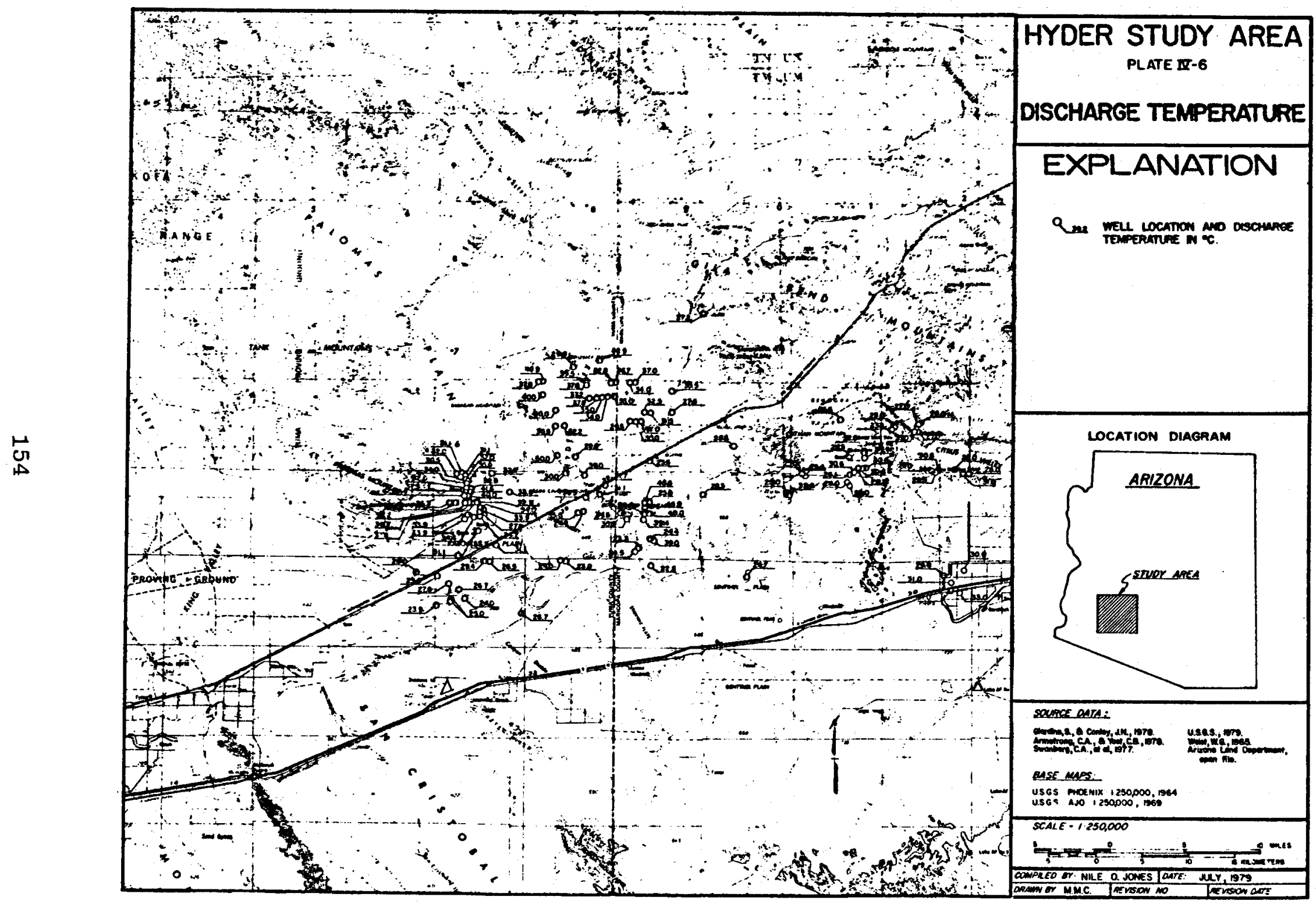




\section{C}

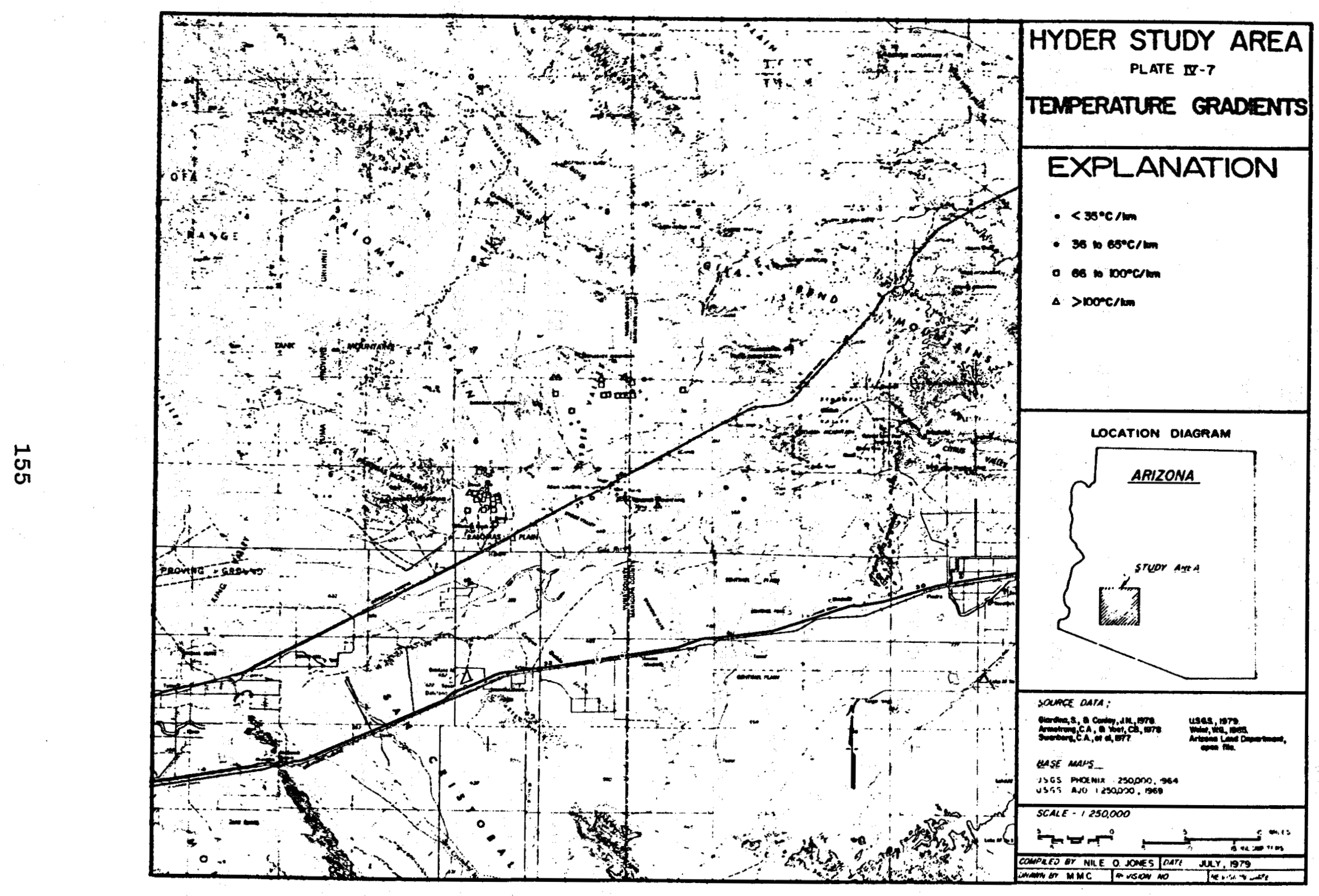




$\frac{\text { THE SAN FRANCISCO RIVER BETWEEN CLIFTON, ARIZONA }}{\frac{\text { AND PLEASANTON, NEW MEXICO }}{\text { by James } c \text {. Witcher }}}$

INTRODUCTION

The purpose of this study is to provide timely information on the geothermal resource potential of the San Francisco River between Clifton, Arizona and Pleasanton, New Mexico. The area is a proposed Wild and Scenic River and Wilderness Area. The results of this reconnalssance study and of previous studies at Clifton Hot Springs, Arizona, and the lower San Francisco Hot Springs, New Mexico, show very high potential for significant geothermal energy resources in this area. At a time of acute energy problems, it would be unwise to designate these lands wilderness without a detailed geologic investigation.

\section{GEOLOGIC SETTING}

Physiographically, the San Francisco River between Clifton, Arizona, and Pleasanton, New Mexico, lies in the transition zone between the Colorado Plateau and the Basin and Range province. The river cuts through a sequence of nearly flatlying Tertiary volcanics and does not expose pre-Tertiary rocks except immediately north of Clifton.

Basaltic andesite and andesite are the largest fraction of volcanic rocks exposed along the river. Significant, but volumetrically minor ash flow tuffs and felsite intrusions are also exposed. 
The basaltic andesite and andesite sequences consist of flows one to five meters thick. The individual flows are frequently separated by volcanic brecclas, volcano-clastic sediment, or thin lenses of fluvial sands and gravels (Berry, 1976 and Ratte and others, 1969).

One or more ash flow tuffs up to several hundred meters thick are interbedded in the basaltic andesite sequence. The ash flow tuff exposed along the river is discontinuous because of either faulting or localized deposition of the tuff. Several felsite dikes intrude the basaltic andesites and ash flow tuffs and occupy fracture or fault zones oriented e1ther $N 65^{\circ} \mathrm{W}$ or $\mathrm{N} 30^{\circ} \mathrm{E}, \pm 10^{\circ}$.

The volcanic sequence is probably middle-Tertiary age and may correlate with the Blue Range volcanics north of the area and with the Datil-Mogollon volcanics east of the area (Berry, 1976). West-northwest and north-northwest striking faults displace the volcanics exposed along the river. Where light-colored ash flow tuff is interbedded with dark colored basaltic andesite, fault displacements are easily recognized but are difficult to identify where only basaltic andesites are exposed.

North-northeast orfented faults are the largest structural features along the San Francisco River. The dominant northnor theast structural trend may reflect the southward continuation of the Blue Fault zone described by Ratte and others (1969) as a northeast oriented set of normal faults 15 to 30 miles wide that extends from Clifton, Arizona, to Apache Creek, New Mexico. 
The northeast orientation of the major faults in the area is notable because most large Tertiary faults in southeastern Arizona and southwestern New Mexico are oriented northwest.

\section{WATER CHEMISTRY}

Table 1 is a list of chemical analyses of springs and the river in the area. Figure 1, a Piper diagram, illustrates the chemistry of water from the San Francisco River and from springs in the study area. The locations of samples taken for chemical analysis are shown in Figure 2. A Piper diagram shows the milliequivalent percent of the major cations or anions to total cations in each sample. Two chemical distributions are apparent on the Piper diagram. The hot springs and sample 82 are sodium chloride waters while the cold springs and river samples are magnesiumrich bicarbonate waters with approximately equal concentrations of sodium and calcium. Compared to the cold springs, the hot springs are high in silica and lithium concentrations.

\section{WATER CHEMISTRY INTERPRETATION}

The sodium-calcium bicarbonate chemistry from the cold springs and the San Francisco River is typical of water whose constituents are derived from the dissolution of volcanic rocks (Garrels and Mackenzie, 1967).

Samples 78,83 and 89 do not plot in the fields occupied by the majority of cold springs and river waters plotted on a Piper diagram (Figure 1). Samples 78 and 83 are from springs whose temperatures are slightly greater than the mean $20^{\circ} \mathrm{C}$ temperature of the other cold springs and the river samples. Sample 78, Lopez Spring, has a measured temperature of $23^{\circ} \mathrm{C}$ and discharges in the bottom of a dry wash several meters above 
Piper Diagram of Water Chemistry of springs along the San Francisco River between Clifton, Arizona and Pleasanton, N. Mex.
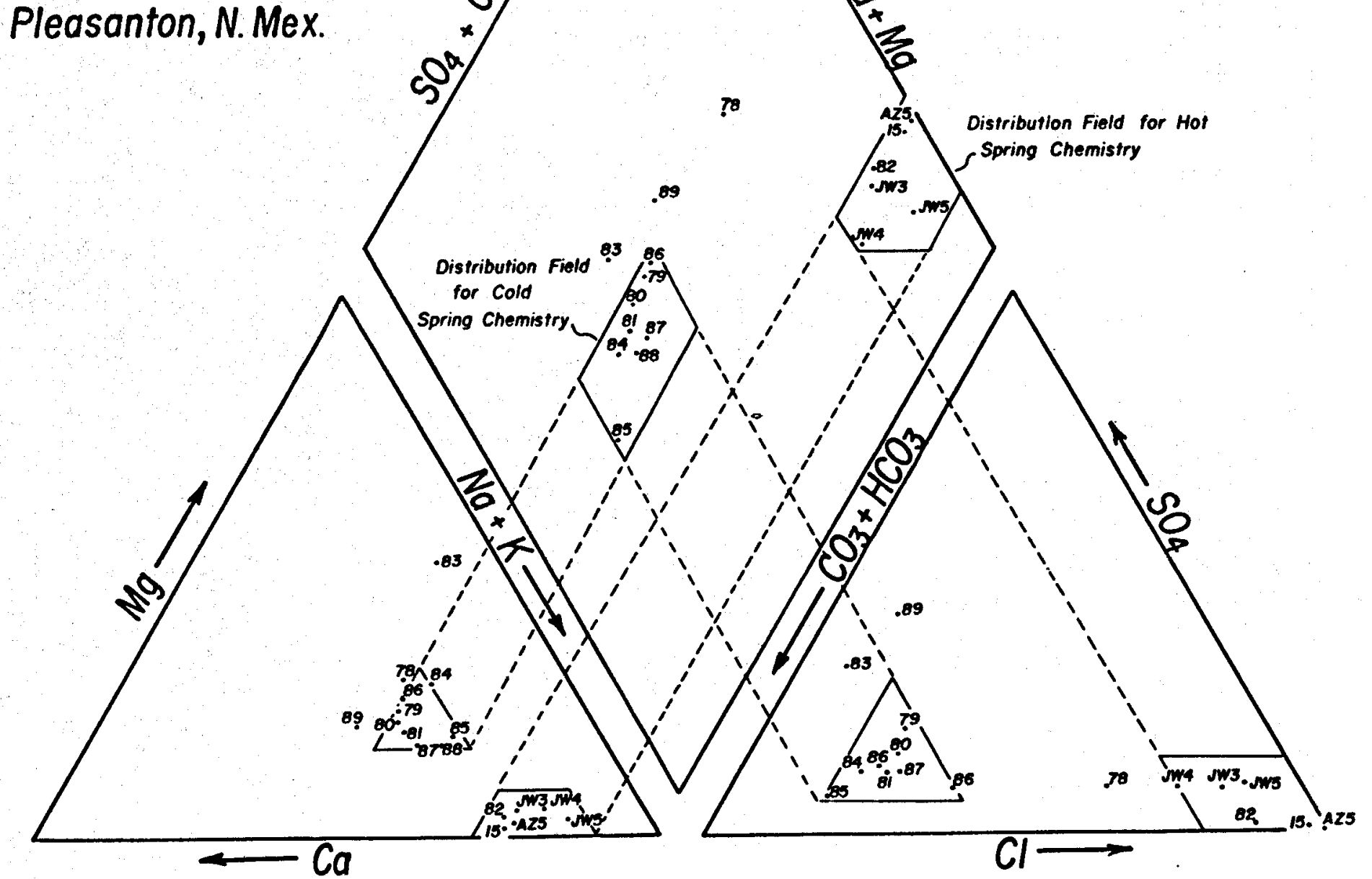

78 Numbers Refer to Somples in Table 1 

MAP OF STUDY AREA SHOWING SAMPLE LOCATIONS AND LOCATION OF THE RECONNAISANCE
GEOLOGIC MAP.

T.2s.

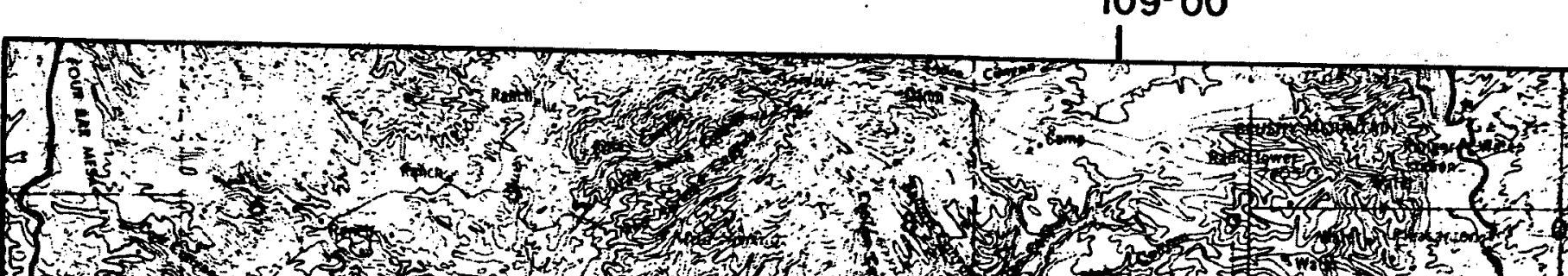

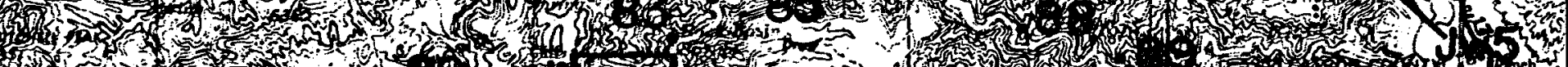

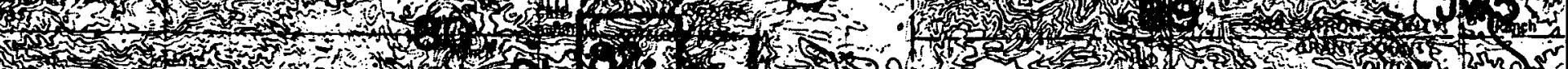

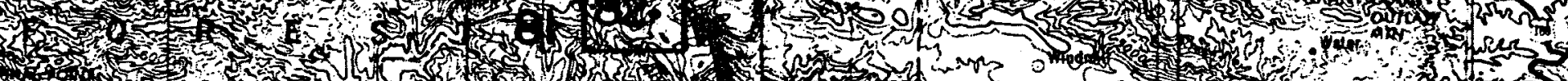

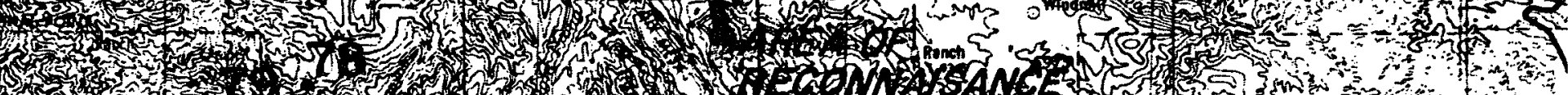

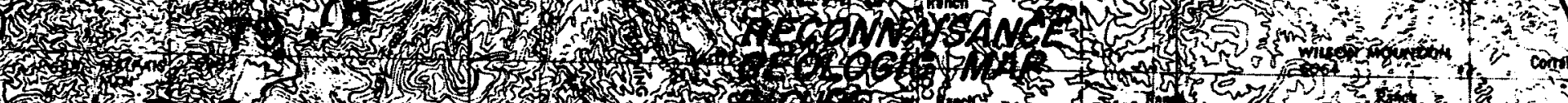
(3) H.

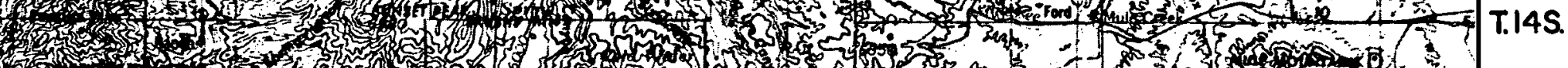

T.4S.

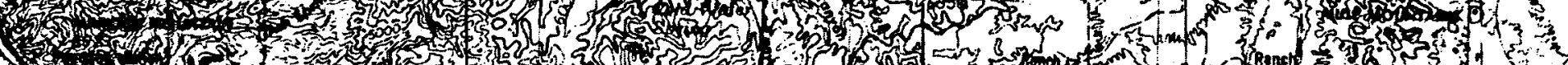

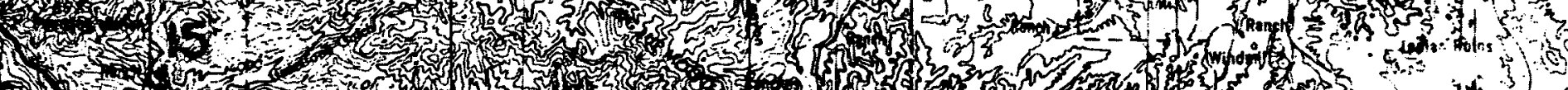

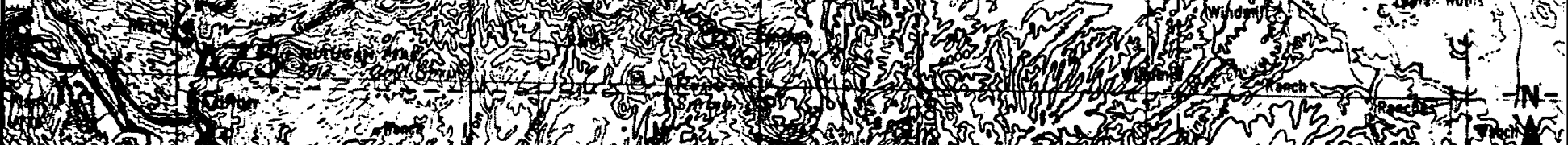

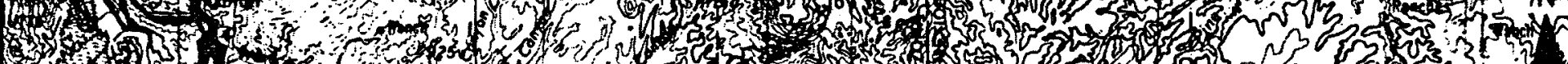

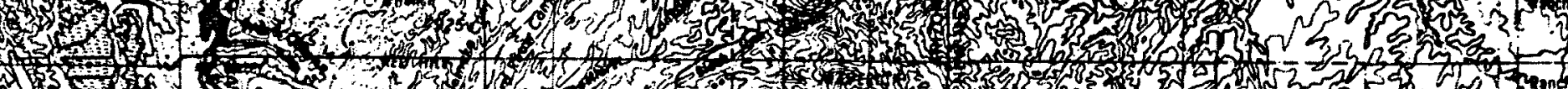

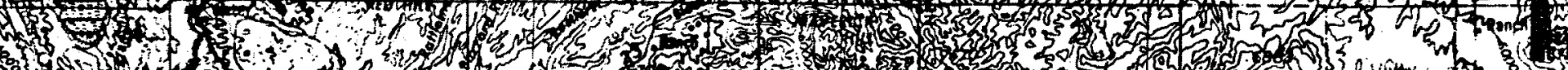

T.5S.

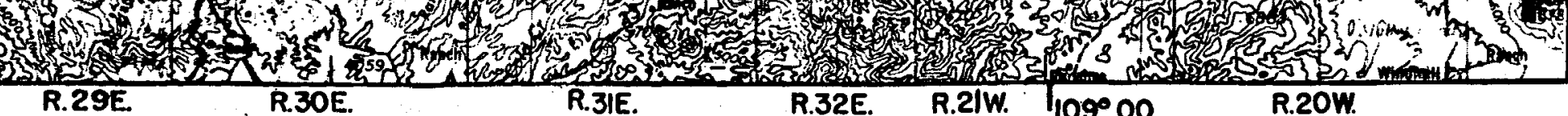

Bose from US.G.S. AMS sheet, Clifton.

Scole: 1:250,000

Contour interval 200 feet.

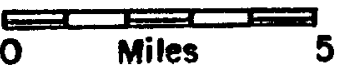


the San Francisco River. The spring is relatively concentrated in chloride which may indicate mixing of cold bicarbonate water with chloride rich hot water. The silica and lithium concentrations are also higher than concentrations observed in most cold springs. Sample 83 discharges from between basaltic andesite flows in a cliff on the north side of the San Francisco River. Travertine is deposited as the spring waters cascade down the cliff. While the temperature, silica concentration and I1thium concentrations are above normal for the other cold springs, it is doubtful if this spring represents a mixed geothermal water because the chloride concentration is low and is not typical of the high-chloride hot springs. Because the silica concentration of Sample 83 is approaching equilibrium with amorphous silica, its silica content may result from dissolution of silicate minerals in the basaltic andesite and not from the result of temperature dependent solution of quartz or chalcedony.

Sample 89 is from Mule Creek at the San Francisco River confluence. The slightly different chemical signature of the Mule Creek sample probably reflects dissolution of different rocks in 1 ts source area.

High sodium chlorlde, lithium, and silica concentrations are found in the hot spring samples. Sample 82 is a sodium chloride water with a measured temperature of $26.6^{\circ} \mathrm{C}$, significantly higher than the mean annual temperature $\left(13.0^{\circ} \mathrm{C}\right)$ and the average temperature of cold springs $\left(18.0^{\circ} \mathrm{C}\right)$ along the San Francisco River. Sample 82 appears to have an origin similar 
to the hot springs found upstream along the San Francisco River at the lower San Francisco Hot Springs, New Mexico and downstream at Clifton Hot Springs, Arizona.

\section{GEOTHERMOMETRY}

The water solubility of quartz, chalcedony and opal are directly temperature dependent (Fournier, R.O., and Rowe, J.J., 1966); therefore, the $\mathrm{SiO}_{2}$ content of groundwater is a valuable tool for delineating geothermal potential (Fournier, R.0., White, D.E., and Truesdell, A.H., 1974; Fournier, R.0., and Truesdell, A.H., 1974; and Arnorsson, S., 1975).

The silica concentration in springs may be used to predict the minimum reservoir temperatures of geothermal systems. The technique is advantageous because $\mathrm{SiO}_{2}$ approaches solution equilibrium slowly at lower temperatures (Fournier, 1977). Thus, a cooled geothermal water will retain most of its originally-high silica concentration after leaking from the reservoir. Silica geothermometry is most applicable where the hot water is not mixed with cold water. If mixing of hot and cold water is known to occur, mixing model calculations may be performed to predict reservoir temperatures (Fournier and Truesdell, 1974). The silica geothermometers are used assuming that temperature dependent solution of quartz or chalcedony controls the silica concentration observed in the sampled waters. Table 2 summarizes the chalcedony and quartz geothermometer temperatures for the samples collected along the San Francisco River.

The molal concentrations of sodium, potassium, and calcium 
are used in a $\mathrm{Na}-\mathrm{K}-\mathrm{Ca}$ geothermometer which is based on an empirical relationship between the proportions of potassium to sodium, the square root of calcium to sodium, and the measured temperatures of known geothermal systems. The Na-KCa geothermometer is less reliable in predicting reservoir temperatures than the silica geothermometer because the cations used in the calculation may be involved in many non-temperature dependent reactions after the hot waters leak out of the geothermal reservoir such as ion exchnage or precipitation of calcium carbonate. The Na-K-Ca geothermometer calculations for the water samples along the San Francisco River are shown in Table 2.

A major modification to the $\mathrm{Na}-\mathrm{K}-\mathrm{Ca}$ geothermometer has recently been developed by Fournier and Potter, (1978). The modified $\mathrm{Na}-\mathrm{K}-\mathrm{Ca}$ temperatures, with a correction for magnesium concentrations are also tabulated in Table 2 under the heading of magnesium correction.

\section{GEOTHERMOMETER INTERPRETATION}

Figure 3 is a plot of the magnestum corrected $\mathrm{Na}-\mathrm{K}-\mathrm{Ca}$ geothermometer temperatures versus the chalcedony geothermometer temperatures. Theoretically, the data should plot on Line A because the two geothermometers should give the same reservoir temperature for each sample (Figure 3 ). The data are in fair agreement with Line A. However, the hot spring data plot to the left of line $A$, and the cold spring data plot to the right of Line $A$. When samples 82,15 and AZ5 are replotted using the quartz geothermometer, they are in better agreement with Line $A$. 


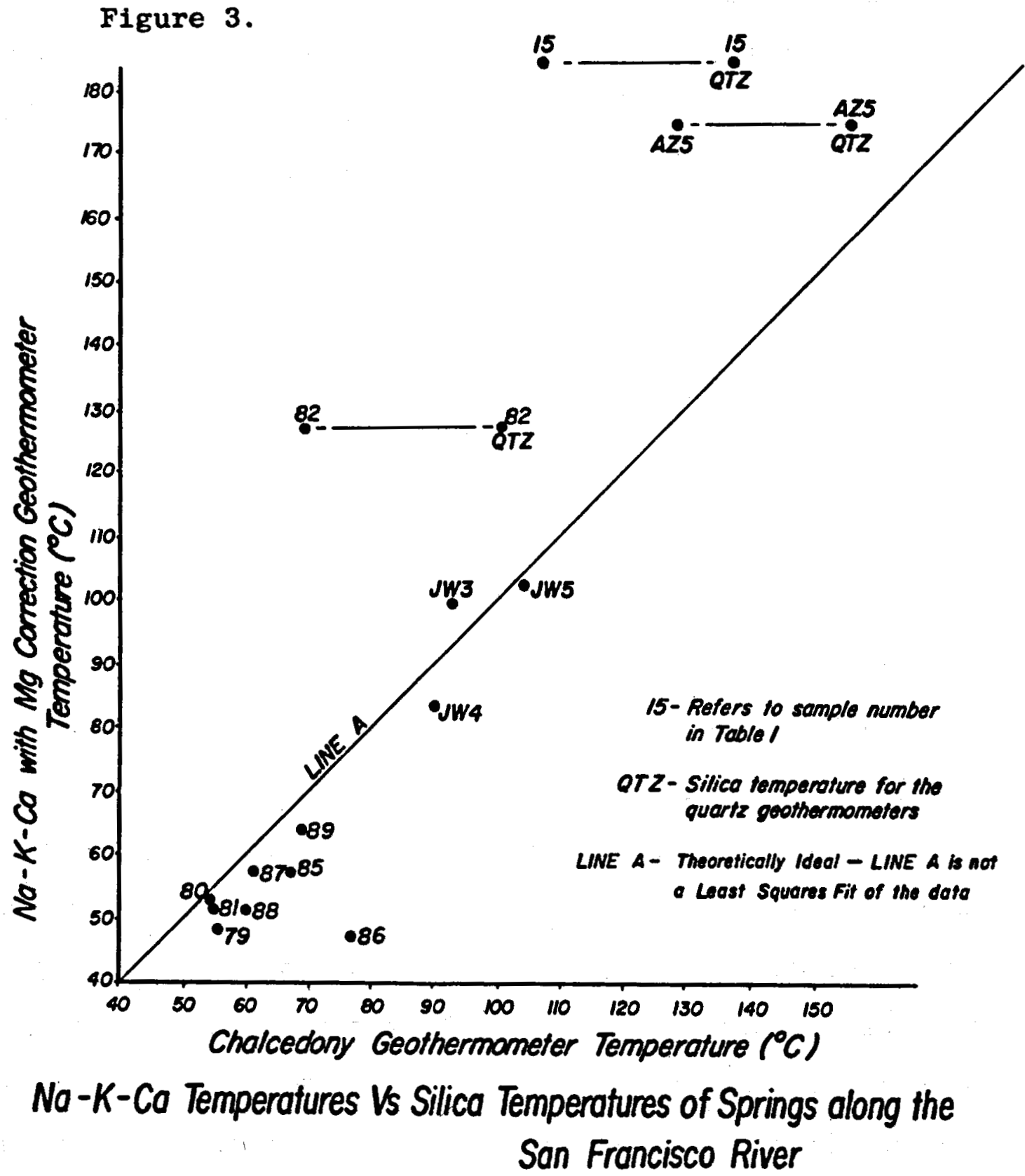


Samples 82, 15 and AZ5 may have equilibrated with quartz. The minor loss of silica due to silica precipitation after the water leaves the geothermal reservolr and cools conductively may account for the hot spring data plotting on the left of Line A. Also, if the spring waters are mixtures of hot and cold water, lower silica geotemperatures result which would cause samples 18, 15 and AZ5 to plot on the left of Line A. The higher silica geothermometer temperatures of the cold springs probably result from excess silica derived from the dissolution of alumino-silicate minerals in high $\mathrm{CO}_{2}$ conditions near the surface.

\section{GEOLOGIC INTERPRETATION}

A reconnalssance geologic map of the Martinez ranch area is shown in Figure 4. The warm spring, Sample 82, is located in this area. The warm spring gives a high $\mathrm{Na}-\mathrm{K}-\mathrm{Ca}$ geothermometer temperature of 126.9 and is chemically. equivalent to Clifton Hot Springs. Clifton Hot Springs indicate good geothermal potential for a high temperature $\left(>150^{\circ} \mathrm{C}\right.$ ) geothermal resource (Witcher, 1979). Sample 82 occurs near the intersection of a north-northeast trending fault, intruded by latite, and a northwest trending normal fault. The northwest trending fault has bad post-latite movement because the latite is truncated by the fault; and slicken sices indicating movement on the nor thwest trending fault are also observed on the fault plane surface in the latite. The fault intersection 


\section{EXPLANATION}

"82 Spring sample number (see Table I)

Foult

Inferred Foult

P Spring

- Trovertine

Tertiary? Latite Intrusive

D. Alluvium

Tertiory Basaltic Andesite

[Fis] Tertiary Ash Flow Tuff, Volcano-Clastic sediment and minor Basaltic Andesite Flows 
Reconnaissance Geologic Map of the Martinez Ranch Area Along the San Francisco River, Arizona $109^{\circ} 10^{\prime}$ $109^{\circ} 07^{\prime} 30^{\prime \prime}$

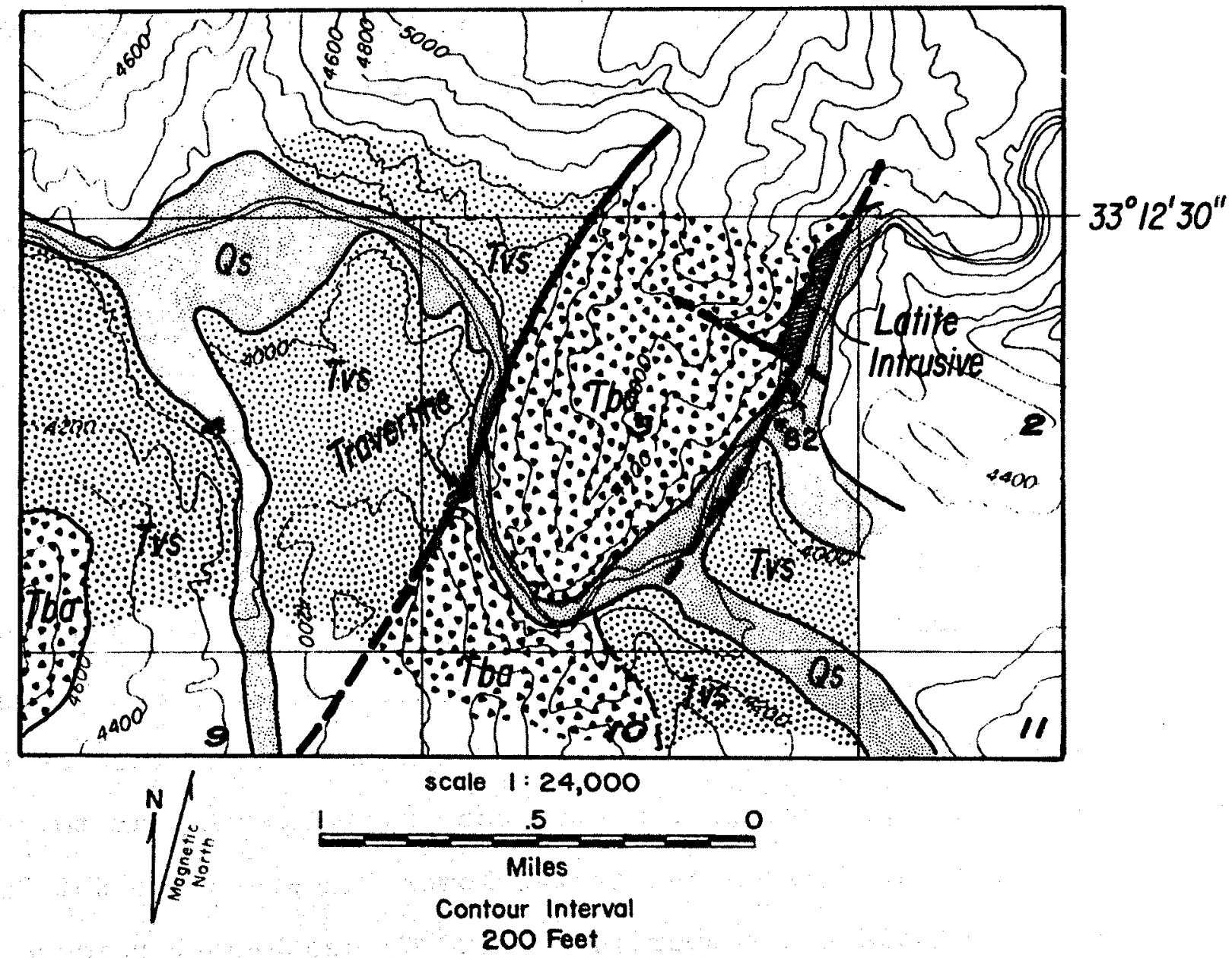

Figure 4. Base from USGS $75^{\circ}$ Min advance sheet, Big Lue Mtns. NW 1961 Geology from field reconnaisance mapping and photo geologic Interpretation, USGS $7.5^{\circ}$ Min Orthophoto quad. Big Lue Mins. NW 
may provide fracture permeability for the flow of geothermal water. Another possible geothermal manifestation occurs along a second north-northeast trending fault west of the fault intruded by latite. A hump-backed travertine deposit along this fault trace possibly indicates the location of former hot springs. The north-northeast structures appear to have significant control on the surface occurrence of warm springs in the San Francisco River area.

GEOTHERMAL POTENTIAL

Geologic reconnaissance of the San Francisco River between Clifton, Arizona, and Pleasanton, New Mexico, shows the area to have high potential for the occurrence of high to moderate temperature $\left(>120^{\circ} \mathrm{C}\right)$ geothermal reservoirs, which could be utilized for electrical power production, for direct use, and desalination to augment existing water supplies. Areas surrounding the Clifton Hot Springs and the lower San Francisco Hot Springs are designated as federal KGRA's (known geothermal resource areas). The Martinez Ranch area along the San Francisco River has geothermal resource possibilities similar to those observed at Clifton and at the lower San Francisco Hot Springs. High to moderate temperature $\left(>120^{\circ} \mathrm{C}\right)$ geothermal resources are indicated in all of these areas by this and earlier studies.

\section{RECOMMENDATIONS}

If any part of the San Francisco River between Clifton, Arizona, and Pleasanton, New Mexico is designated as a wilderness or wild and scenic river, it will close the region to 
all geothermal development and exploration at a time of acute energy crisis. Due to the potentially significant geothermal energy resources in the San Francisco River area, it is recommended that the area not be designated as a wilderness or a wild and scenic river. In addition, detailed geologic mapping should be undertaken in order to understand the structure and geologic history of the area. This is essential in locating geothermal reservoirs. Complete sampling of groundwaters for geochemical and geothermometry studies should be accomplished in the area. Geochemical methods are rapid, inexpensive exploration tools in geothermal energy resource evaluation.

Specific sites showing geothermal resource potential should then be studied in detail to include geophysical techniques and shallow depth heat flow hole drilling. 
TABLE 1

Chemical Analysis of Springs and River in the San Francisco River Area

from Clifton, Arlzona, to Pleasanton, New Mexico

\begin{tabular}{|c|c|c|c|c|c|c|c|c|c|c|c|c|c|}
\hline Sample\# & $\mathrm{pH}$ & TDS & $\mathrm{Na}$ & $\mathbf{K}$ & $\mathrm{Ca}$ & $\mathrm{Mg}$ & $\mathrm{Cl}$ & $\mathrm{HCO}_{3}$ & $\mathrm{SO}_{4}$ & $\mathrm{SIO}_{2}$ & B & $F$ & $\mathbf{L 1}$ \\
\hline 78 & 7.7 & 939 & 120 & 4.0 & 63 & 41.3 & 254 & 225 & 52 & 69 & 4.3 & 1.5 & 0.20 \\
\hline 79 & 7.9 & 205 & 27 & 2.6 & 16 & 7.5 & 26 & 110 & 28 & 36 & 3.7 & 1.0 & 0.03 \\
\hline 80 & 8.0 & 209 & 27 & 3.1 & 16 & 6.7 & 23 & 104 & 18 & 35 & 4.1 & 1.0 & 0.03 \\
\hline 81 & 7.7 & 216 & 28 & 3.0 & 16 & 6.1 & 23 & 108 & 15 & 36 & 3.8 & 1.0 & 0.04 \\
\hline 82 & 7.7 & 6594 & 1500 & 75.0 & 420 & 31.0 & 3391 & 750 & 56 & 48 & 4.0 & 1.5 & 2.46 \\
\hline 83 & 8.7 & 479 & 48 & 0.6 & 11 & 32.5 & 16 & 225 & 85 & 76 & 4.1 & 1.2 & 0.16 \\
\hline 84 & 7.8 & 316 & 45 & 3.3 & 18 & 14.1 & 33 & 194 & 24 & 48 & 4.1 & 1.3 & 0.05 \\
\hline 85 & 7.9 & 322 & 53 & 3.5 & 20 & 9.3 & 36 & 281 & 18 & 46 & 3.4 & 1.5 & 0.05 \\
\hline 86 & 7.7 & 487 & 62 & 5.5 & 33 & 18.6 & 68 & 182 & 21 & 55 & 3.7 & 1.3 & 0.05 \\
\hline 87 & 8.0 & 314 & 43 & 3.9 & 22 & 7.4 & 29 & 125 & 18 & 41 & 3.8 & 1.3 & 0.05 \\
\hline 88 & 7.7 & 238 & 31 & 2.9 & 16 & 5.7 & 23 & 121 & 18 & 39 & 2.7 & 1.2 & 0.04 \\
\hline 89 & 8.1 & 249 & 19 & 5.7 & 18 & 5.6 & 10 & 77 & 49 & 47 & 3.1 & 1.0 & 0.02 \\
\hline JW3* & 7.9 & 992 & 207 & 15.6 & 50 & 6.8 & 445.3 & 129.4 & 57.6 & 75 & 0.3 & 1.4 & 0.48 \\
\hline JW4* & 7.9 & 768 & 216 & 11.3 & 39 & 7.4 & 294.6 & 136.7 & 44.2 & 65 & 0.2 & 1.5 & 0.34 \\
\hline JW5* & 7.8 & 1280 & 406 & 18.8 & 54 & 6.9 & 574.3 & 107.4 & 90.3 & 91 & 0.4 & 1.8 & 0.65 \\
\hline 15 & 7.5 & 7205 & 2016 & 178 & 601 & 13 & 4400 & 114 & 58 & 95 & - & - & $\cdots$ \\
\hline AZ5* & 7.9 & 14548 & 3586 & 243 & 926 & 22.9 & 7485 & 150 & 0 & 131 & 1.51 & 3.5 & 6.96 \\
\hline
\end{tabular}

*Data from Swanberg and others (1977) 
Location and Geothermometer Temperatures of

\section{Sirings and River in the San Francisco River Area}

from Clifton, Arizona, to Pleasanton, New Mexico

${ }^{\circ} \mathrm{C}$

$$
\text { Chemical }
$$

${ }^{\circ} \mathrm{C}$

Samplell

78

79

80

81

$\underset{7}{H}$
Name

Lopez Spring

San Francisco River

San Francisco River

San Francisco River

Spring

Spring

Spring

Spring

Spring

Spring

Spring

Mule Crcek

JW3* Lower San Francisco Hot Springs, NM

JW4* Lower San Francisco Hot Springs, NM

JW5* Lower San Francsico Hot Springs, NM

15 Clifton Hot Springs

AZ5* Clifton Hot Springs

\begin{tabular}{|c|c|c|c|c|}
\hline $\begin{array}{c}\text { Measured } \\
\text { Temperature }\end{array}$ & $\begin{array}{c}{ }^{\circ} \mathrm{C} \\
\mathrm{Na}-\mathrm{K}-\mathrm{Ca} \\
\end{array}$ & $\begin{array}{l}\text { Geothermometry } \\
\mathrm{Na}-\mathrm{K}-\mathrm{Ca} \\
\mathrm{Mg} \text { Corrected }\end{array}$ & $\begin{array}{c}{ }^{\circ} \mathrm{C} \\
\text { Chalcedony } \\
\end{array}$ & $\begin{array}{c}{ }^{\circ} \mathrm{C} \\
\text { Quartz } \\
\end{array}$ \\
\hline 23.0 & 47.8 & 47.8 & 88.9 & 117.6 \\
\hline 21.0 & 47.4 & 47.4 & 56.3 & 87.2 \\
\hline 20.0 & 52.2 & 52.2 & 55.0 & 86.0 \\
\hline 20.0 & 51.6 & 51.6 & 56.3 & 87.2 \\
\hline 26.6 & 155.5 & 126.9 & 69.9 & 100.1 \\
\hline 25.5 & 21.8 & -- & 94.4 & 122.5 \\
\hline 16.1 & 56.6 & 56.6 & 69.9 & 100.1 \\
\hline 24.0 & 57.8 & 57.2 & 67.9 & 98.1 \\
\hline 17.2 & 62.8 & 46.8 & 76.8 & 106.5 \\
\hline 17.0 & 57.1 & 57.1 & 62.4 & 92.9 \\
\hline 16.1 & 51.6 & 51.6 & 60.0 & 90.7 \\
\hline 14.4 & 64.2 & 64.2 & 68.9 & 99.1 \\
\hline 43.3 & 161.3 & 99.9 & 93.6 & 121.9 \\
\hline 40.0 & 97.0 & 83.2 & 85.6 & 114.6 \\
\hline 48.9 & 147.9 & 102.5 & 104.9 & 132.1 \\
\hline 61.0 & 186.9 & 184.5 & 107.5 & 134.5 \\
\hline 48.0 & 179.8 & 173.9 & 128.1 & 153.0 \\
\hline
\end{tabular}

*Data from Swanberg and others (1977)

T3S, R30E, Sec. 16 DBB

T3S, R3OE, Sec, 21 BCA

T3S, R31E, Sec, 6 ABCC

T3S, R31E, Sec. $5 \mathrm{ABCB}$

T3S, R31E, SeC. 3 ADCC

$33^{\circ} 12.6^{\prime} \mathrm{N} 109^{\circ} 7.6^{\prime} \mathrm{W}$

$33^{\circ} 13.6^{\prime} \mathrm{N} 10906.5^{\prime} \mathrm{W}$

$33^{\circ} 13.8^{\prime} \mathrm{N} 10905.9^{\prime} \mathrm{W}$

$33^{\circ} 14.2^{\prime} \mathrm{N} 109^{\circ} 2.7^{\prime} \mathrm{W}$

$33^{\circ} 13.7^{\prime} \mathrm{N} 109^{\circ} 1.8^{\prime} \mathrm{W}$

$33012.6^{\prime} \mathrm{N} 109^{\circ} 0.6^{\prime} \mathrm{W}$

$33^{\circ} 12.8^{\prime} \mathrm{N} 108^{\circ} 58.6^{\prime} \mathrm{W}$

T12S, R2OW, Sec. 33 BAC

T12S, R20W, Sec. $23 \mathrm{CB}$

T12S, R20W, Sec. $23 \mathrm{CAC}$

T4S, R30E, Sec. $18 \mathrm{C}$

T4S, R30E, Sec. 18 DC

\section{Geo thermometry \\ $\mathrm{Na}-\mathrm{K}-\mathrm{Ca}$}

47.8

47.4

2.2

126.9

56.6

46.8

51.6
128.1 
Arnorsson, Stefan, 1975, Application of the Silica Geothermometer in Low Temperature Hydrothermal Areas in Iceland: American Journal of Science, Volume 275, pp. 763-784.

Berry, Robert C., 1976, Mid-Tertiary Volcanic History and petrology of the White Mountain Volcanic Province, Southeastern Arizona: Unpub. Ph.D. Dissertation, Princeton University, $317 \mathrm{p}$.

Davis, Stanley N., 1964, Silica in Streams and Ground Water: American Journal of Science, Volume 262, pp. 870-891.

Fournier, R.O., and Rowe, J.J., 1966, Estimation of Underground Temperatures from Silica Content of Water from Hot Springs and Wet Steam Wells: American Journal of Science, Volume 264, pp. 685-697.

Fournier, R.O., and Truesdell, A.H., 1973, An Empirical Na-K-Ca Geothermometer for Neutral Waters: Geochem et Cosmochim Acta, Volume 37, pp. 1255-1275.

Fournier, R.O., and Truesdell, A.H., 1974, Geochemical Indicators of Subsurface Temperature - Part 2, Estimation of Temperature and Fraction of Hot Water Mixed with Cold Water: U.S. Geological Survey Journal of Research, Volume 2, No. 3, pp. 263-270.

Fournier, R.O., White, D.E., and Truesdell, A.H., 1974, Geochemical Indicators of Subsurface Temperature - Part 1 , Basic Assumptions: U.S. Geological Survey Journal of Research, Volume 2, No. 3, pp. 259-262.

Fournier, R.O., 1977, Chemical Geothermometers and Mixing Models for Geothermal Systems: Pergamon Press, Geothermics, Volume 5, pp. 41-50.

Fournier, R.O., and Potter, R.W., 1978, A Magnesium Correction for the Na-K-Ca Chemical Geothermometer: U.S. Geological Survey Open-File Report 78-986, 23 p.

Garrels, Robert M., and Mackenzie, Fred, T., 1967, Origin of the Chemical Compositions of Some Springs ard Lakes, in Equilibrium Concepts in Natural Water Systems: American Chemical Society, Washington, D.C., pp. 222-242.

Ratte, J.C., Landis, E.R., Gaskill, D.L., and Raabe, R.G., 1969, Mineral Resources of the Blue Range Primitive Area, Greenlee County, Arizona, and Catron County, New Mexico: U.S. Geological Survey Bulletin 1261-E, p.1, 1:62,500. 
Swanberg, C.A., Morgan, P., Stoyer, C.H., and Witcher, J.C., 1977, An Appraisal Study of the Geothermal Resources of Arizona and Adjacent Areas in New Mexico and Utah and Their Value for Desalination and Other Uses: New Mexico Energy Institute Report 6, New Mexico State University, $76 \mathrm{p}$.

U.S. Geological Survey, 1971, Clifton 1:250,000 AMS Sheet.

U.S. Geological Survey, 7.5 Min. Orthophoto Quad, Big Lue Mountains, NW

U.S. Geological Survey, 1961, 7.5 Min. Advance Map, Big Lue Mountains, NW

Witcher, J.C., 1979, A Progress Report of Geothermal Investigations in the Clifton Area, in Geothermal Reservoir Site Evaluation in Arizona, Semi-Annual Progress Report for the Perlod July 15, 1978 - Januar: 15, 1979, Department of Energy Contract EG-77-S-02-4362: Ar1zona Bureau of Geology and Mineral Technology, Geological Survey Branch, Geothermal Group, University of Arizona, pp. 26-41. 